\title{
Development of BromoTag: A "Bump-and-Hole"-PROTAC System to Induce Potent, Rapid, and Selective Degradation of Tagged Target Proteins
}

\author{
Adam G. Bond, "I Conner Craigon, "II Kwok-Ho Chan, Andrea Testa, Athanasios Karapetsas, \\ Rotimi Fasimoye, Thomas Macartney, J. Julian Blow, Dario R. Alessi, and Alessio Ciulli*
}

Cite This: J. Med. Chem. 2021, 64, 15477-15502

Read Online

ABSTRACT: Small-molecule-induced protein depletion technologies, also called inducible degrons, allow degradation of genetically engineered target proteins within cells and animals. Here, we design and develop the BromoTag, a new inducible degron system comprising a Brd4 bromodomain L387A variant as a degron tag that allows direct recruitment by heterobifunctional bumped proteolysis targeting chimeras (PROTACs) to hijack the VHL E3 ligase. We describe extensive optimization and structureactivity relationships of our bump-and-hole-PROTACs using a CRISPR knock-in cell line expressing model target BromoTagBrd2 at endogenous levels. Collectively, our cellular and mechanistic data qualifies bumped PROTAC AGB1 as a potent,


fast, and selective degrader of BromoTagged proteins, with a favorable pharmacokinetic profile in mice. The BromoTag adds to the arsenal of chemical genetic degradation tools allowing us to manipulate protein levels to interrogate the biological function and therapeutic potential in cells and in vivo.

\section{INTRODUCTION}

Targeted protein degradation is rapidly established as a powerful modality of chemical biology and drug discovery. Proteolysis targeting chimeras (PROTACs) are heterobifunctional molecules which hijack the ubiquitin proteasome system by recruiting an E3 ubiquitin ligase to a target protein of interest, promoting the protein's polyubiquitination and subsequent proteasomal degradation. ${ }^{1-4}$ The ability to rapidly remove a protein entirely, as opposed to merely blocking a single activity or an interaction, offers an attractive approach to study the target protein biology, therapeutic potential, and pharmacological properties. However, the PROTAC approach is limited by the availability of small-molecule ligands that engage the protein target. While good ligands are available for many target proteins, a large proportion of the human proteome lacks such binding ligands. ${ }^{5}$ It is therefore important to develop new methodologies to address unligandable proteins, many of which remain underexplored in biology and disease.

To deal with proteins that lack binding ligands, a complementary strategy involves modifying the gene which encodes for the protein of interest by adding a tag, also called the "degron tag", which allows small molecules to bind to and directly recruit the E3 ligase to ubiquitinate and promote degradation of the target protein. Examples of tag-based degron systems include the auxin-inducible degron (AID), whereby a target protein is fused with the AID/LAA17 degron sequence that is recognized by the plant cullin RING E3 ligase TIR1 in the presence of the molecular glue auxin ${ }^{6}$ or in recent developments of bumped analogues selectively targeting mutant TIR $1 ;{ }^{7,8}$ HaloPROTACs, bifunctional molecules that bear a chloroalkane warhead which forms a covalent bond with a HaloTag-fused target protein at one end and a von HippelLindau (VHL) E3 ligase ligand at the other end; ${ }^{9,10}$ and dTAGs, bifunctional molecules which bind to a FKBP12 $2^{\mathrm{F} 36 \mathrm{~V}}$ tag that is fused to the target protein at one end and either cereblon $(\mathrm{CRBN})$ or VHL ligases at the other end. ${ }^{11,12}$ These approaches have been used successfully to induce targeted protein degradation in cells and in vivo, but they all have disadvantages and limitations. For example, AID methods can be leaky (background target degradation even prior to auxin dosage), require high concentrations of auxin to work, and also require inconvenient additional engineering to allow for the expression of the non-native plant E3 ligase; all limitations lead

Received: August 29, 2021

Published: October 15, 2021 
A

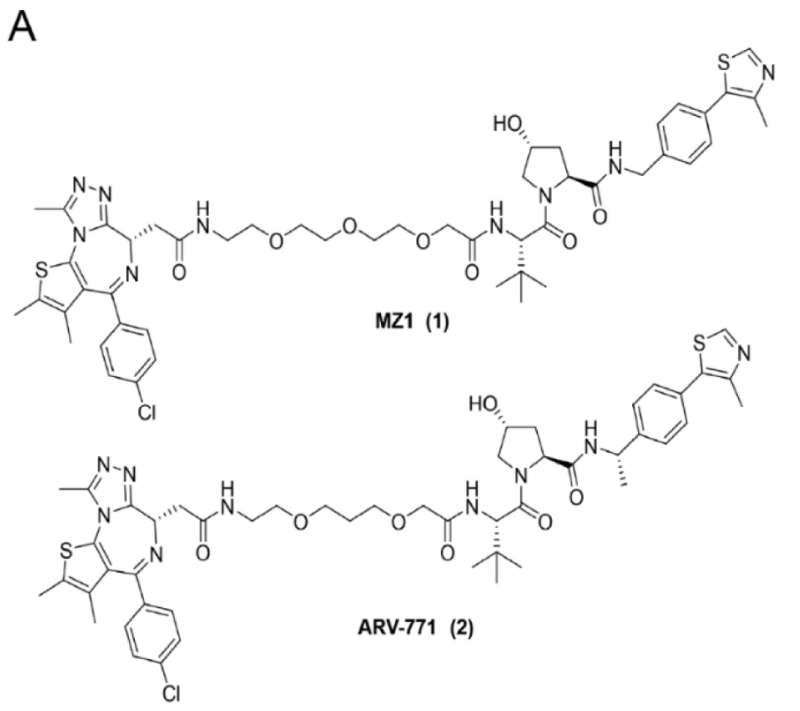

B<smiles>Cc1sc2c(c1C)C(c1ccc(Cl)cc1)=N[C@@H](CC(=O)OC(C)(C)C)c1nnc(C)n1-2</smiles>

(+)-JQ1 (3)

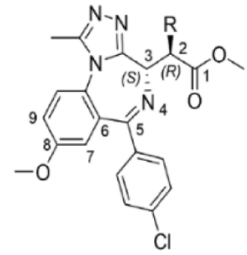

ME: $R=M e(5)$
ET: $R=E t$

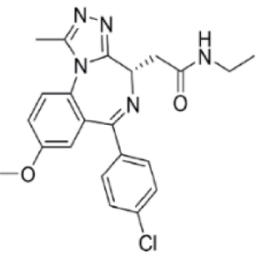

I-BET762 (4)

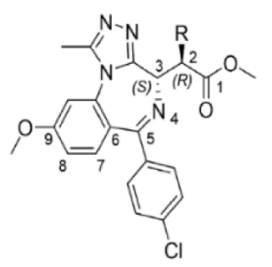

9-ME-1: $R=\operatorname{Me}(7)$

9-ET-1: $R=E t \quad(8)$
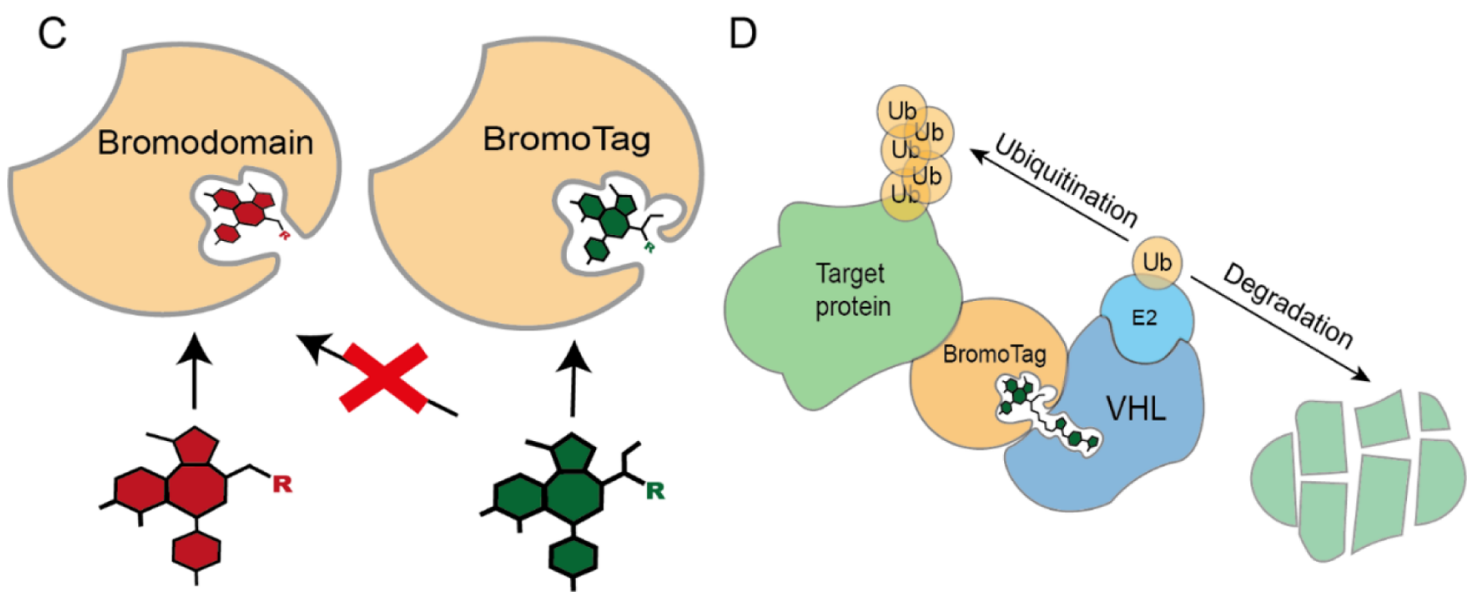

Figure 1. (A) Pan-selective BET degraders, MZ1 and ARV-771. (B) Pan-selective BET inhibitors, (+)-JQ1 and I-BET762 (top). Allele-specific bumped BET inhibitors, ME, ET, 9-ME-1, and 9-ET-1 (bottom). (C) Tailoring the "bump-and-hole" approach to BET bromodomains to produce a high-affinity selective pairing that can be utilized as a degron system. (D) Conceptualization of the BromoTag degron approach.

to possible off-target effects. HaloPROTACs react covalently with the tagged protein and thus require stoichiometric modification of the tagged protein to induce maximal degradation, thereby lacking the substoichiometric, catalytic mode of action, which is an advantage of non-covalent degraders. As a result, HaloPROTACs tend not to achieve complete target degradation and tend to plateau at $D_{\max } \sim 85-$ 90\% even at high doses. ${ }^{9,10}$ CRBN-based dTAGs bear phthalimide-based ligands which exhibit chemical instability and off-target effects. ${ }^{13}$

There is a significant scope to expand the chemical and biological space of degron-tag technologies, so we set out to develop a novel system that offers a complementary approach, alternative to the existing methods. In this work, we describe the development of a novel degron tag called the "BromoTag". The new tag system leverages significant developments and discoveries in the past decade from our laboratory on both PROTAC degraders ${ }^{14-17}$ and allele-selective bump-and-hole $(\mathrm{B} \& \mathrm{H})$ targeting $^{18-21}$ of the bromo and extra terminal (BET) bromodomain proteins $\mathrm{Brd} 2, \mathrm{Brd} 3$, and $\mathrm{Brd} 4$. We describe the structure-based design and development of cooperative bumped PROTAC compounds designed to target a mutant Brd4 bromodomain degron tag for the degradation of an endogenously CRISPR-tagged target protein. Our best-in-class degrader system is optimized in terms of degradation potency, speed, and target selectivity, while showing no off-target degradation of endogenous BET proteins and thus lacking cytotoxicity, and is qualified as an appropriate chemical tool for biological investigation in living cells and in vivo.

\section{RESULTS AND DISCUSSION}

2.1. Background and Design Rationale of the BromoTag. To design the BromoTag, we hypothesized that we could leverage our potent and selective BET bromodomain recruiting PROTAC MZ1 (1, Figure 1A) and its target BET bromodomain as a degron tag. ${ }^{14}$ Our extensive mechanistic and structural characterization of MZ1 mode of action highlighted that MZ1, with its VHL-bound E3 ligase, formed the most stable, cooperative, and long-lived ternary complex with the second bromodomain of $\mathrm{Brd} 4\left(\mathrm{Brd} 4^{\mathrm{BD} 2}\right)$, despite consisting of the pan-selective BET bromodomain ligand (+)-JQ1 (3, Figure 1B). This preferential recruitment leads to productive ubiquitination and preferential degradation of endogenous Brd4. ${ }^{15,17,22,23}$ These findings suggested that $\mathrm{Brd} 4{ }^{\mathrm{BD} 2}$ could provide an attractive degron tag for ligandinduced degron technologies; however, the use of MZ1 

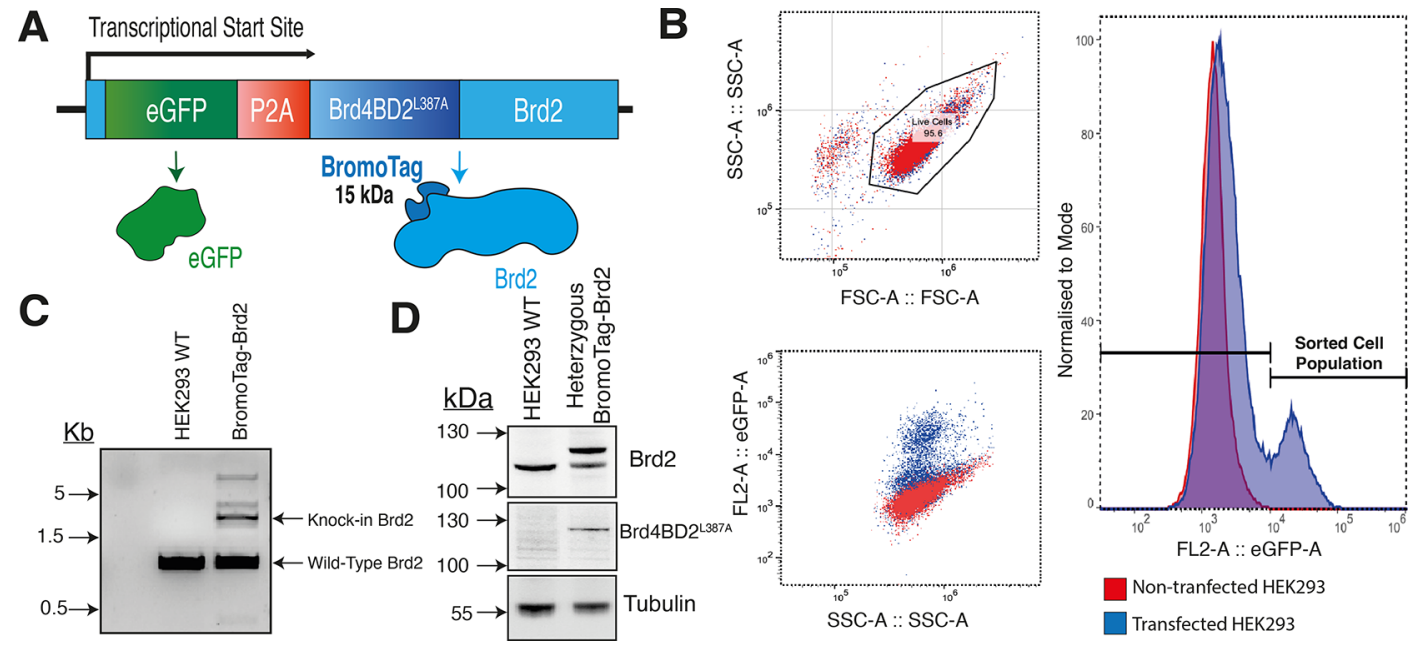

Figure 2. Design and development of a heterozygous knock-in BromoTag-Brd2 HEK293 cell line. (A) Design of the knock-in construct used in the development of the CRISPR construct. (B) FACS single cell sort of HEK293 cells based on GFP expression. Successive single cells were sorted into individual wells of a 96-well plate. (C) Junction PCR using genomic DNA of an expanded GFP-expressing clone paired against parental HEK293. (D) Western blot demonstrating the selectivity of the polyclonal Brd4BD2 $2^{\mathrm{L} 387 \mathrm{~A}}$ antibody.

induces confounding downstream effects from its potent induced degradation of all endogenous BET proteins.

To circumvent this limitation, we leveraged engineered variants of BET bromodomains that we previously described, which create a cavity (or "hole") in the BET bromodomains enabling allele-selective binding by a bulkier synthetic BET ligand bearing a "bump". ${ }^{18}$ Our previous, extensive work developing such a "bump-and-hole" approach identified a Leu residue in the ligand binding site, strictly conserved across all BET family members. Using site-directed mutagenesis, the Leu residue was mutated to a smaller Ala or Val to create a hole that maintained domain stability and ligand-binding capacity. Simultaneously, the pan-selective BET inhibitor I-BET762 (4, Figure 1B) was modified by introducing a methyl or ethyl "bump" to yield ME and ET (5 and 6, respectively, Figure 1B), and later on 9-ME-1 and 9-ET-1 (7 and 8, respectively, Figure 1B), which differ by having a methoxy shift from the $8^{\prime}$ to $9^{\prime}$ position of the fused phenyl ring in the I-BET762 scaffold. ${ }^{18,20}$ The steric "bump" was accommodated into the newly formed hole while clashing with the wild-type protein, allowing us to engineer exquisite allele-selectivity within BET bromodomains. ${ }^{18,20}$ We therefore reasoned that using such bumped BET ligands, within the context of the MZ1 PROTAC degrader, would enable selective degradation of target proteins fused to a mutant $\mathrm{Brd} 4^{\mathrm{BD} 2}$ domain, without detrimental degradation of endogenous wild-type BET proteins. Such bespoke "bump-and-hole"-PROTACs (B\&H-PROTACs) would therefore offer a complementary, generalizable system of PROTAC-inducible degron tag technology.

2.2. Development of a Knock-In Cell Line with the BromoTag Fused to Endogenous Brd2 Using CRISPR. To establish the BromoTag platform and support the degrader structure-activity relationships (SARs) to identify the best compound, we sought a practical and simple system that enables us to best optimize not only the degradation efficiency but also the selectivity profile of our degraders. To this end, the endogenous BET family protein $\mathrm{Brd} 2$ was chosen as a model target due to the availability of a well-established antibody for $\mathrm{Brd} 2$ detection, and the expression of a single protein isoform detected as a single band in the western blot. ${ }^{24}$ Because Brd2 contains endogenous bromodomains and is degraded by $\mathbf{1}$ and other BET PROTACs, we reasoned that a heterozygous knock-in cell line allows us to monitor simultaneously both ontarget degradation (BromoTagged-Brd2) and off-target degradation (untagged Brd2) using the same antibody. Together with the potential off-target degradation of the other BET proteins Brd3 and Brd4, this system thus enables us to best monitor protein degradation selectivity. We therefore decided to add the BromoTag at the N-terminus of the endogenous $\mathrm{Brd} 2$ gene locus using CRISPR knock-in methodologies, thereby yielding a chimeric protein bearing three bromodomains (the exogenous BromoTag, in addition to the endogenous $\mathrm{Brd} 2^{\mathrm{BD} 1}$ and $\mathrm{Brd} 2^{\mathrm{BD} 2}$ ). Hereafter, we refer to ontarget activity as the degradation of BromoTag-Brd2 and offtarget activity as any degradation of either untagged $\operatorname{Brd} 2$ or endogenous Brd3 or Brd4.

The BromoTag itself was designed based on our previous work to develop a B\&H strategy for BET family proteins. ${ }^{18}$ To maximize our chances of producing a successful and complementary degron for our MZ1-based B\&H-PROTACs, we chose to use $\mathrm{Brd} 4^{\mathrm{BD} 2 \mathrm{~L} 387 \mathrm{~A}}$ as the degron "BromoTag" construct (comprising residues 368-440 of human Brd4, size $\sim 15 \mathrm{kDa}$, full amino acid sequence in Supporting Information Figure S1). The specific bromodomain $\mathrm{Brd} 4{ }^{\mathrm{BD} 2}$ was chosen because it forms the strongest and most cooperative ternary complex with 1 and VCB (VHL/ElonginC/ElonginB), ${ }^{15}$ facilitating productive ubiquitination and rapid and potent degradation of endogenous Brd4 by MZ1. Moreover, the specific L387A mutation on $\mathrm{Brd} 4^{\mathrm{BD} 2}$ was chosen instead of L387V because it shows greatly reduced binding affinity for acetylated histone tail partners compared to the wild-type or L$\mathrm{V}$ domain, ${ }^{20}$ suggesting that it would be less likely to introduce unwanted neo functionality or protein-protein interactions when used as a tag.

At the outset of the project, we chose HEK293 cells for our CRISPR knock-in experiments to establish a model BromoTag cell line due to their ease of transfection, good level of CRISPR efficiency, ${ }^{10}$ and high level of expression of all the three BET proteins. HEK293 cells were transfected simultaneously with three plasmid constructs, two harboring cas9 $9_{\mathrm{D} 10 \mathrm{~A}}$ which are $\mathrm{N}$ terminal Brd2-specific gRNAs. The other plasmid held the knock-in sequence of the $\mathrm{Brd} 4^{\mathrm{BD} 2 \mathrm{~L} 387 \mathrm{~A}}$ BromoTag. The full 
knock-in construct contained in the $5^{\prime}-3^{\prime}$ direction an eGFP fluorescent marker, a P2A splice sequence followed subsequently by the $\mathrm{Brd} 4^{\mathrm{BD} 2 \mathrm{~L} 387 \mathrm{~A}}$ sequence (Figure $2 \mathrm{~A}$, see Supporting Information Figure S1 for full DNA sequences of components). After transfection, the cells underwent fluorescence-activated cell sorting (FACS) to identify GFP expressing single cells denoting successful integration of the knock-in construct (Figure 2B). The cells were expanded from GFP expressing single cells, and an optimal heterozygous knock-in clone was identified and chosen. A subsequent junction PCR was undertaken, demonstrating successful heterozygous integration of the BromoTag $\mathrm{N}$-terminally to $\mathrm{Brd} 2$ (Figure 2C and Supporting Information Figure S2). Since HEK293 is a hypo-triploid cell line, we suspect that the disparity in band intensity present in the junction PCR for the wild-type over the knock-in cell line is due to single-allele integration of our knock-in, leaving potentially two wild-type non-modified alleles (Figure 2C). This heterozygous clone was further validated via western blot using a Brd2 antibody and by independently observing BromoTag-Brd2 expression using an antibody against the BromoTag (Figure 2D and Supporting Information Figure S3). This antibody was raised in-house using a Brd4BD2 ${ }^{\mathrm{L} 387 \mathrm{~A}}$ protein recombinantly expressed in Escherichia coli as the antigen. This heterozygous BromoTagBrd2 HEK293 cell line was then subsequently genotyped, showing successful in-frame knock-in of the eGFP-P2ABromoTag knock-in at the N-terminus of $\operatorname{Brd} 2$ (see Supporting Information Figure S4). This cell line will now be referred to as BromoTag-Brd2 HEK293 herein.

2.3. Development of First-Generation, I-BET762Based B\&H-PROTACs. In order to combine both B\&H and PROTAC technologies, we set out to make an initial series of B\&H-PROTACs using MZ1 as a template and replacing its BET targeting ligand with a variety of bumped I-BET762 derivatives we had previously developed. ${ }^{18,20}$ We first inspected our ternary complex crystal structure between $\mathrm{Brd} 4^{\mathrm{BD} 2}, 1$, and VCB (Figure 3A) and superposed onto $\mathrm{Brd} 4^{\mathrm{BD} 2}$, the co-crystal structures of bumped I-BET chemical probes 6 and 7 in complex with $\mathrm{Brd} 2^{\mathrm{BD} 2 \mathrm{~L} 383 \mathrm{~A}}$ (Figure 3B) and $\mathrm{Brd2}{ }^{\mathrm{BD} 2 \mathrm{~L} 383 \mathrm{~V}}$ (Figure 3C), respectively. The chemical structures of 1 and 6 (Figure 3B) and 1 and 7 (Figure 3C) adopt a very similar binding mode, with the carbon adjacent to the methyl ester bearing ethyl or methyl bump in $\mathbf{6}$ and 7, respectively, aligning nicely with the non-bumped, bromodomain-binding portion of $\mathbf{1}$. With these structural insights, we proceeded to synthesize the first-generation I-BET-based B\&H-PROTACs (Scheme 1).

We first reduced VH032-PEG3 azide $\mathbf{9}^{14}$ with a suspension of $10 \%$ palladium on carbon in methanol under an atmosphere of hydrogen gas to yield terminal amines which were then coupled to racemic I-BET762-derived acids, 10-13, via standard amide coupling conditions with 1-[bis(dimethylamino) methylene]-1H-1,2,3-triazolo[4,5-b]pyridinium 3-oxid hexafluorophosphate (HATU), 1-hydroxy7-azabenzotriazole (HOAt), and diisopropylethylamine (DIPEA) in dimethylformamide (DMF) or dichloromethane (DCM) to yield bumped I-BET PROTACs, DAT487-489 (15-17), and the non-bumped control, MZP-15 (14), each as a mixture of two diastereomers (Scheme 1).

With this initial library in hand, we set out to evaluate the activity and selectivity of our I-BET-based B\&H-PROTACs by treating our heterozygous BromoTag-Brd2 HEK293 cells with $1 \mu \mathrm{M}$ of compounds $15-17$ or $1 \mu \mathrm{M}$ of control
A
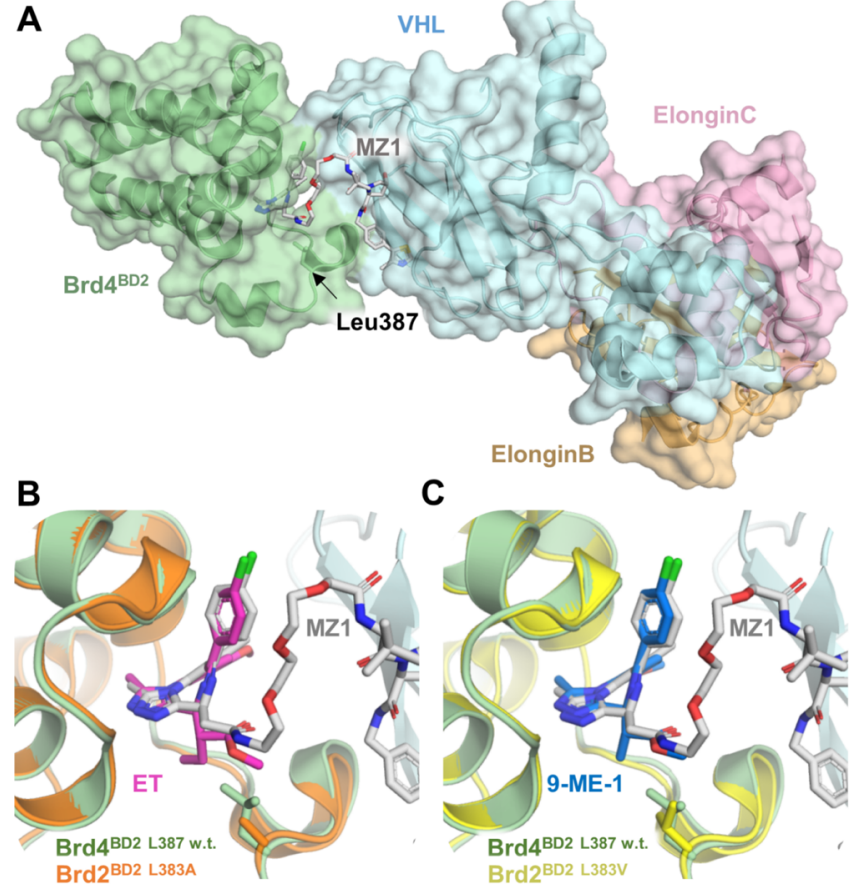

C

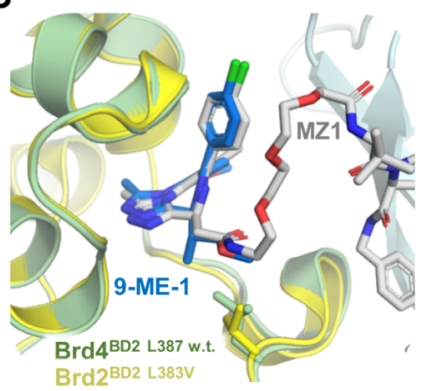

Figure 3. (A) Ternary complex between $\mathrm{Brd} 4{ }^{\mathrm{BD} 2}$ (green, cartoon/ surface representation), MZ1 (1, stick, gray carbons), and VCB (VHL: blue; elongin C: pink; elongin B-pale orange; and cartoon/ surface representations). Leu387 (stick, green) is indicated by an arrow (PDB code: 5T35). Alignment of $\mathrm{Brd}^{\mathrm{BD} 2}$ (pale green, cartoon representation, 5T35) with (B) $\mathrm{Brd} 2^{\mathrm{BD} 2 \mathrm{~L} 383 \mathrm{~A}}$ (orange, cartoon representation, 4QEW) and (C) $\mathrm{Brd}^{\mathrm{BD} 2} \mathrm{~L} 383 \mathrm{~V}$ (yellow, cartoon representation, 5O3C), co-crystallized with $\mathrm{MZ1}$ (1, stick, gray carbons), ET (6, stick, pink carbons), and 9-ME-1 (7, stick, blue carbons), respectively. Brd4 ${ }^{\text {BD2 } 2 . T . ~ L e u 387 ~(s t i c k, ~ p a l e ~ g r e e n ~ c a r b o n s) ~}$ and mutants $\mathrm{Brd2} \mathrm{BD}^{\mathrm{BD} 2 \mathrm{~L} 383 \mathrm{~A}}$ Ala383 (stick, orange carbons) and $\mathrm{Brd} 2^{\mathrm{BD} 2 \mathrm{~L} 383 \mathrm{~V}}$ Val383 (stick, yellow carbons) are highlighted.

compounds MZP-15 (14), MZ1 (1), and cis-MZ1 for $6 \mathrm{~h}$, which is the sufficient time to achieve effective MZ1-induced BET protein degradation (Figure 4A). The cells were harvested, and the subsequent lysate was analyzed via western blot using antibodies against BET proteins: $\mathrm{Brd} 2, \mathrm{Brd} 3$, and Brd4 (Figure 4A). To our disappointment, none of the initial $\mathrm{B} \& \mathrm{H}-\mathrm{PROTAC}$ compounds induced detectable degradation of the BromoTag-Brd2.

In understanding the potential reasons for the inactivity of our initial set of compounds, we were curious to observe the apparent significant lower activity of non-bumped 14 relative to 1 across all the three BET family members (Figure 4A, see Supporting Information Figure S5). While its presence as a diastereomeric mixture may contribute to the lower apparent activity of 14 compared to enantiomerically pure 1 , we turned our attention to the chemical structures of the two compounds. Compounds 1 and $\mathbf{1 4}$ are otherwise structurally identical except that they differ in the BET bromodomain binding portion: 1 (JQ1-based) bears a dimethylthiophene group fused to the diazepine ring, while 14 (I-BET762-based) bears an 8OMe-phenyl group in the equivalent position (cf. Figure 1B and Scheme 1). We therefore turned to our structural superposition between the ternary crystal structure $\mathrm{Brd} 4^{\mathrm{BD} 2} /$ $1 / \mathrm{VHL}$ and the binary structures of the bumped BET ligands and inspected in more detail the region of the structures around the different groups. This analysis revealed that the methoxy group of the fused phenyl ring present in I-BET762- 
Scheme 1. Synthesis of I-BET762-Based B\&H-PROTACs and Non-bumped Control Compound ${ }^{a}$<smiles></smiles>

( \pm )-8-ET-OH: 8-OMe, $\quad \mathrm{R}=\mathrm{Et}$ (11)

( \pm )-9-ME-OH: 9-OMe, $\mathrm{R}=\mathrm{Me}(12)$

(土)-9-ET-OH: 9-OMe, R= Et (13)

${ }^{a}$ Reaction conditions: (a) $10 \% \mathrm{Pd} / \mathrm{C}, \mathrm{H}_{2}, \mathrm{MeOH}$, r.t., and 3 h; (b) 10, HATU, DIPEA, DCM, r.t., and 18 h; and (c) bumped I-BET acid 11, 12, or 13; HATU; HOAt; DIPEA; DMF; r.t.; and 18 h. * indicates relative configuration at the specified stereogenic centers in the molecule.

derived ligands would clash with His110 present in VHL (Figure 4B). The oxygen atom of the 8-OMe of 6 would be $\sim 3.0 \AA$ away from the carbon atom between the two nitrogen atoms of the His110 side chain, which is below the lower limit for van der Waal's interactions. We reasoned that such a structural clash would destabilize the MZ1-like PROTAC ternary complex, explaining the lower degradation activity of the I-BET762-based compounds. This observation led to the decision to replace the 8 -OMe-phenyl group in the BET binding portion of the PROTACs with the dimethyl-thiophene group to develop compounds much more closely resembling the full chemical structure of MZ1 as a design strategy to minimize any potential disruption in the desired ternary complex and enhance BromoTag degradation activity.

2.4. Development of Second-Generation, JQ1-Based B\&H-PROTACs. To overcome the limitations presented by our I-BET762-based B\&H-PROTACs, we next designed a new set of eight JQ1-based compounds (Table 1). Around this time in the development of the project, we learnt of another BET targeting PROTAC, ARV-771 (2, Figure 1A), ${ }^{25}$ that is structurally similar to $\mathbf{1}$ and also potently degrades the BET proteins. Chemically, 2 consists of the same pan-selective BET bromodomain ligand, (+)-JQ1 (3, Figure 1B), but differs from 1 by having a shorter, more lipophilic linker (minus $-\mathrm{CH}_{2} \mathrm{O}-$ ) and an extra benzylic methyl group in the VHL ligand $\mathrm{VH} 032,{ }^{26}$ which is known to boost the VHL binding affinity. ${ }^{27}$ To maximize the chemical diversity and hence our chance to identify a potent BromoTag degrader, we designed four bumped PROTAC compounds based on $\mathbf{1}$ and four based on $2 .{ }^{25}$ For each set of four, two compounds would contain either a more sterically conserved methyl bump or a more sterically demanding ethyl bump. Each methyl- or ethylbumped BET bromodomain ligand would then be conjugated to the linker via an amide bond to resemble the parent compound or via an ester bond. Our reasoning for choosing the less conventional ester conjugation was based on our previous observation that bumped BET ligands bearing an ester group adjacent to the alkyl bump group were significantly more stable compared to their parent non-bumped analogues. ${ }^{20}$

To synthesize our bumped JQ1 ligands, we adapted the route described by Filippakopoulos et al. and utilized the latestage alkylation described by Baud et al. and Runcie et al. (Scheme 2). ${ }^{18,20,28}$ First, ( \pm )-Fmoc-Asp(OMe)-OH (26) was treated with thionyl chloride in DCM and converted to the acid chloride before being refluxed with aminoketone 27 in chloroform to form an "open" amide Fmoc-protected intermediate. This "opened" intermediate is then refluxed in triethylamine to remove the Fmoc protecting group and reveal the free amine, which in the presence of acetic acid, ring-closes to form the thieno-1,4-diazepine, 28. Deprotonation of amide 28 with potassium tert-butoxide in the presence of diethyl chlorophosphate, followed by treatment with acetylhydrazine, forms the methyltriazole ring and yields triazolothienodiazepine ( \pm )-JQ1-OMe (29) as a racemic mixture. 


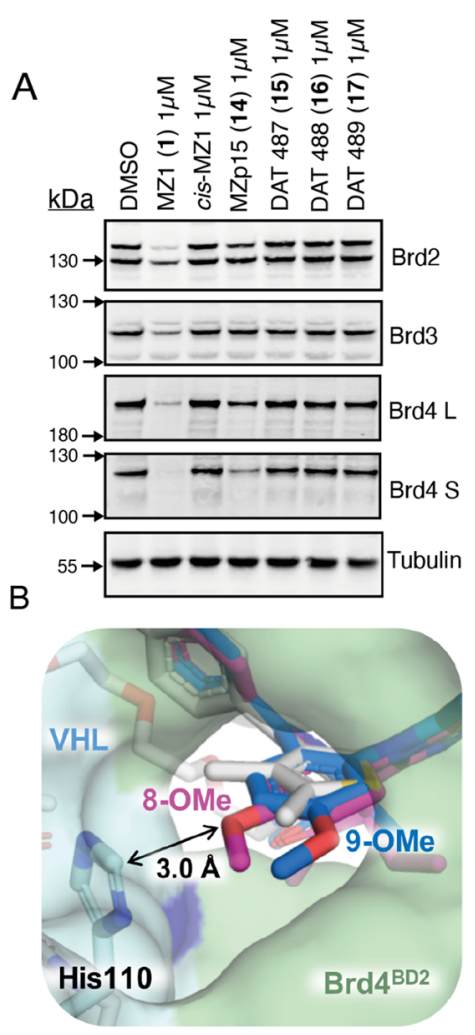

Figure 4. First-generation IBET-762-based B\&H-PROTACs are inactive against BromoTag-Brd2 due to the proposed steric clash in the MZ1-like ternary complex. (A) Western blot data for BET protein levels after the treatment of PROTAC over $6 \mathrm{~h}$ in heterozygous BromoTag-Brd2 HEK293 cells. (B) Alignment of the ternary complex between $\mathrm{Brd} 4^{\mathrm{BD} 2}$ (green, surface representation), MZ1 (1, stick, gray carbons), and VHL (cyan, surface representation) (PDB code: 5T35), with ET (6, 8-OMe, stick, pink carbons, 4QEW) and 9-ME-1 (7, 9$\mathrm{OMe}$, stick, blue carbons, 5O3C) to show the potential clash with VHL by the bulkier 8/9-methoxyphenyl group. His110 is highlighted (stick, cyan carbons).

To introduce either methyl or ethyl bump, 29 was deprotonated with potassium hexamethyldisilazane (KHMDS) at $-78{ }^{\circ} \mathrm{C}$ in tetrahydrofuran (THF). The subsequent enolate was then treated with either methyl or ethyl iodide to yield racemic bumped JQ1-OMe derivatives $30 \mathrm{a}$ and $30 \mathrm{~b}$ or $31 \mathrm{a}$ and $31 \mathrm{~b}$, respectively, as mixtures of diastereomers, which were easily separated using highperformance liquid chromatography (HPLC). Methylation proceeded with a diastereomeric ratio (d.r.) of 1:4 for the desired $\left(2 S^{*}, 3 R^{*}\right)$ isomer to the undesired $\left(2 S^{*}, 3 S^{*}\right)$ isomer. Ethylation proceeded with a d.r. of 1:1.5. The undesired $\left(2 S^{*}, 3 S^{*}\right)$ isomers, $\mathbf{3 0 b}$ and $\mathbf{3 1} \mathbf{b}$, can be epimerized by treating with sodium methoxide in methanol under microwave irradiation to yield a further 1:1 mixture of diastereomers, which, following HPLC separation, yields more of the desired $\left(2 S^{*}, 3 R^{*}\right)$ isomers $30 \mathbf{a}$ and 31 a.

To allow for further functionalization and linker conjugation, methyl esters 30a and 30b were hydrolyzed under mild conditions with lithium hydroxide in THF and water to yield the conjugatable carboxylic acids 32 and 33 as racemic mixtures (Scheme 2).

The next step was to connect linkers 36 and 37 to the VH032-amine, 34, and linkers 38 and 39 to the methylated VH032-amine, 35, under standard amide coupling conditions with HATU and DIPEA in DMF to yield amides 9, 40, 42, and 43 (Scheme 3). Silylethers, 40 and 43 , were cleaved using a solution of tetrabutylammonium fluoride (TBAF) in THF to yield terminal alcohols 41 and 44, respectively, as suitable precursors for ester conjugation.

Azides, 9 and 42, were subsequently reduced with a suspension of $10 \%$ palladium on carbon in methanol under an atmosphere of hydrogen gas to yield terminal amines before being coupled to racemic bumped JQ1 acids, 32 and 33, using (1-cyano-2-ethoxy-2-oxoethylidenaminooxy)dimethylaminomorpholino-carbenium hexafluorophosphate (COMU) and DIPEA in THF to yield amide B\&H-PROTACs, 18-21 as a mixture of diastereomers (Scheme 4).

Finally, alcohols 41 and 44 were coupled to bumped JQ1 acids, 32 and 33, with $N$-(3-dimethylaminopropyl)- $N^{\prime}$-ethylcarbodiimide hydrochloride (EDC. $\mathrm{HCl}$ ) and 4(dimethylamino)pyridine (DMAP) in THF to yield ester B\&H-PROTACs, 22-25, as a mixture of two diastereomers (Scheme 4). The diastereomers formed in each amide and ester case were inseparable by HPLC and were progressed as diastereomeric mixtures for preliminary in cellulo evaluation to screen for BromoTag-Brd2 degradation and selectivity over wild-type BET proteins.

We evaluated the cellular activity of all eight B\&HPROTACs (18-25) in our heterozygous BromoTag-Brd2 knock-in HEK293 cell line at concentrations ranging from 1 $\mathrm{nM}$ to $10 \mu \mathrm{M}$ (Figure 5). Strikingly, all compounds showed a pronounced effect on the degradation of the BromoTag-Brd2 isoform, achieving observable and in most cases complete depletion of BromoTagged-Brd 2 protein. This allowed quantitative analysis of the compounds' on-target degradation potency $\left(\mathrm{DC}_{50}\right)$ and efficacy $\left(D_{\max }\right)$ to build SAR, with quantification performed via detection using both independent antibodies, which compared extremely well in all cases (Table 2).

The best compounds emerged to be 19, 23, and 25, which all harbor an ethyl bump. They showed both potent and complete degradation of the BromoTag-Brd2 isoform, with $\mathrm{DC}_{50}$ values of $250-360,13-80$, and $13-16 \mathrm{nM}$, respectively, and $D_{\max }>75 \%$. Importantly, no observable off-target degradation of the untagged $\mathrm{Brd} 2$ or the other endogenous BET proteins was observed, except minor off-target degradation of $\mathrm{Brd} 3$ observed with 25 at $1 \mu \mathrm{M}$ (Figure 5, see Supporting Information Figures S6-S8), suggesting that these compounds successfully enable highly selective BromoTag degradation. Interestingly, at higher concentrations of 1-10 $\mu \mathrm{M}$ (Figure 5, see Supporting Information Figures S6-S8), esters $\mathbf{2 3}$ and $\mathbf{2 5}$ showed a strong onset of the hook effect, a well-known phenomenon with bifunctional PROTAC degraders where binary interactions between PROTAC/target and PROTAC/E3 ligase outcompete productive ternary complex formation. ${ }^{29}$ In contrast, no hook effect was observed with amide 19. The last ethyl-bumped compound, 21, showed the least complete $\left(D_{\max }<70 \%\right)$ and weakest $\left(\mathrm{DC}_{50} \sim 1 \mu \mathrm{M}\right)$ degradation activity, with a very narrow degradation window also due to strong hook effect at $10 \mu \mathrm{M}$.

All methyl-bumped compounds 18, 20, 22, and 24 also showed strong on-target degradation activity and were on average 2 -fold more potent than their ethyl-bumped counterparts, with $\mathrm{DC}_{50} \mathrm{~s}$ values between 100 and 160, 320 and 400, 20 and 80 , and 5 and $10 \mathrm{nM}$, respectively. However, we observed that all methyl-bumped compounds also induced undesired off-target degradation, thus showing poor selectivity. 
Table 1. Target JQ1-Based B\&H-PROTAC Library



Compound

These results suggest that the methyl group does not provide enough of a steric clash with the conserved Leu residue of the wild-type BET proteins, and that it is much more tolerated than the larger ethyl bump and so is not sufficient to dial out off-target degradation. Since selectivity against endogenous BET protein is a strictly required criterion for a successful BromoTag system, we decided to drop all methyl-bumped compounds at this stage.

It is interesting to note that all esters (22-25) are more potent than their respective amide counterparts $(\mathbf{1 8 - 2 1 )}$ by between 2- and 126-fold in $\mathrm{DC}_{50}$ (Table 2). Recently, we have shown that the amide-to-ester substitution can provide a simple strategy to increase the PROTAC degradation activity due to increased lipophilicity and cellular permeability while maintaining remarkable intracellular stability. ${ }^{30}$ This trend is well reflected in this compound set, as all esters (22-25) were cell-active and showed more potent $\mathrm{DC}_{50}$ and a prominent hook effect at the higher concentrations compared to their amide counterparts.

Taken together, the results from this screen identified three compounds, ET-MZ1 (19), ET-OMZ1 (23), and ET-OARV771 (25) as the most selective BromoTag-Brd2 degraders, meeting criteria for potent on-target activity while largely sparing off-target BET degradation. We therefore took these three compounds forward in the pipeline.

2.5. Synthesis of ET-OMZ1, ET-OARV-771, and ETMZ1 as Single Stereoisomers. We realized that our secondgeneration $\mathrm{B} \& \mathrm{H}-\mathrm{PROTACs}$, while displaying encouraging results, were all synthesized as diastereomeric mixtures, indicating that they would not only contain the active species but also contain an inactive or less-active species that would be expected to lead to an apparent weaker activity and a narrower selectivity window of the compounds. To gain a true degradation profile of the biologically active isomers (eutomers), we next sought to synthesize our current best degraders as enantiomerically pure, single diastereomers. To achieve enantiomerically pure PROTACs, we developed a new stereoselective synthesis to bumped BET ligands, which we disclosed recently. ${ }^{21}$ In brief, our novel stereoselective route allowed us to incorporate the alkyl bump much earlier in the synthesis of the BET-ligand scaffold. To achieve this, we optimized a lithium hexamethyldisilazane (LHMDS)-mediated, diastereoselective alkylation of a di-protected aspartate derivative and took this through to final bumped JQ1 acid 
Scheme 2. Synthesis of Racemic Bumped JQ1 Ligands ${ }^{a}$

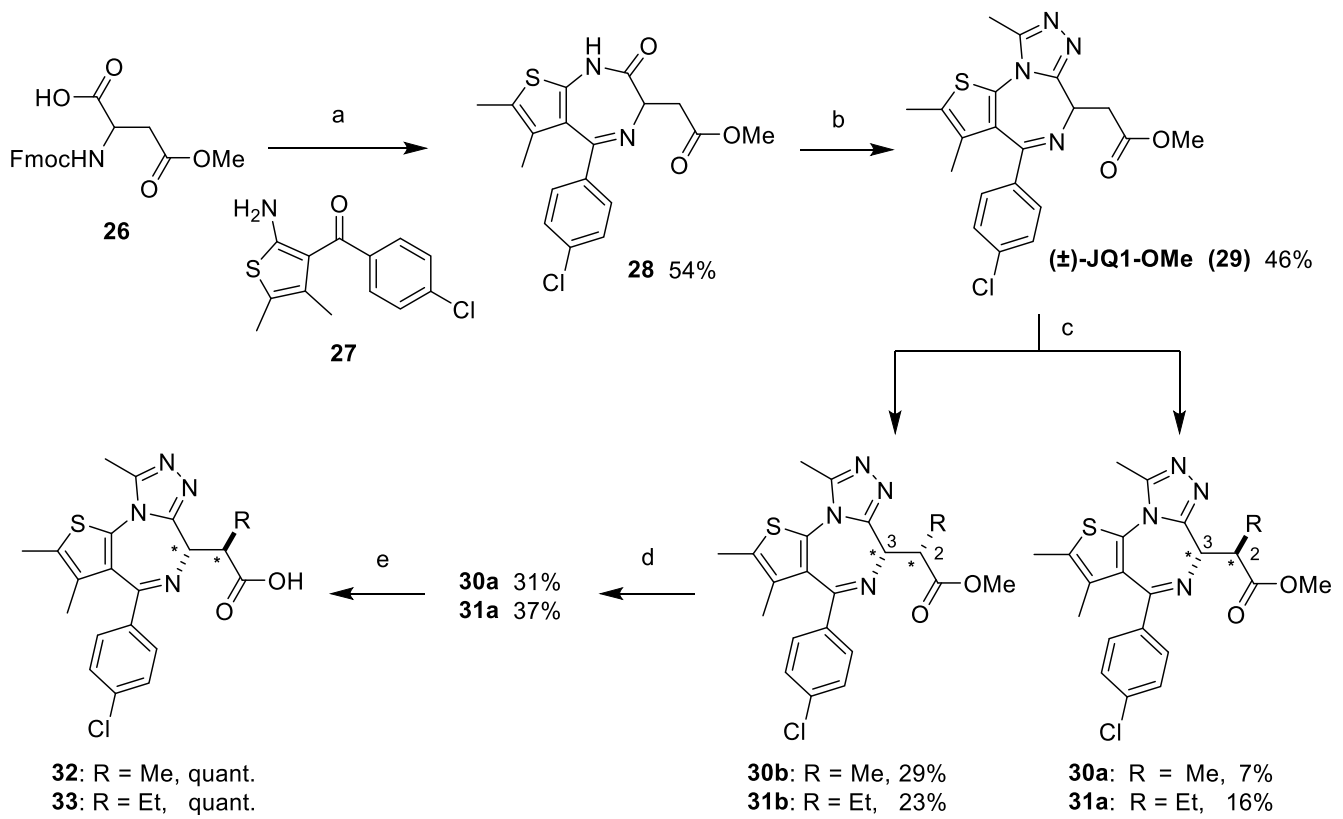

${ }^{a}$ Reaction conditions: (a) (i) $\mathrm{SOCl}_{2}, \mathrm{DCM}$, reflux, and $2 \mathrm{~h}$; (ii) 27, $\mathrm{CHCl}_{3}$, reflux, and $1 \mathrm{~h}$; (iii) TEA, reflux, and 16 h; and (iv) AcOH, 1,2-DCE, $80^{\circ} \mathrm{C}$, and $1 \mathrm{~h}$; (b) (i) KOtBu, THF, -78 to $-10^{\circ} \mathrm{C}$, and $30 \mathrm{~min}$; (ii) (EtO) $)_{2} \mathrm{P}(\mathrm{O}) \mathrm{Cl},-78$ to $-10^{\circ} \mathrm{C}$, and $45 \mathrm{~min}$; (iii) $\mathrm{AcNHNH}$, r.t., and $1 \mathrm{~h}$; (iv) $n$ - BuOH, $90^{\circ} \mathrm{C}$, and $1 \mathrm{~h}$; (c) (i) KHMDS, THF, $-78{ }^{\circ} \mathrm{C}$, and $1 \mathrm{~h}$; (ii) MeI/EtI, $-78{ }^{\circ} \mathrm{C}$ to r.t., and $16 \mathrm{~h}$, and (iii) HPLC separation; (d) (i) $\mathrm{NaOMe}, \mathrm{MeOH}, 120^{\circ} \mathrm{C}$ m.w., and $40 \mathrm{~min}$ and (ii) HPLC separation; and (e) $\mathrm{LiOH}$, THF $/ \mathrm{H}_{2} \mathrm{O}$ 4:1, 30a, r.t., $48-72 \mathrm{~h}, 30 \mathrm{~b}, 45^{\circ} \mathrm{C}$, and 1 wk. * indicates relative configuration at the specified stereogenic centers in the molecule.

analogues with complete retention of stereochemistry and in $>99 \%$ ee. ${ }^{21}$ At this stage in the project, we therefore decided to use the enantiomerically pure ET-JQ1-OH (45) to prepare new B\&H-PROTACs, AGB1 (46), AGB2 (47), and AGB3 (48) (Scheme 5).

For esters 46 and 47 , acid 45 was converted quantitatively to an acid chloride intermediate with thionyl chloride in DCM and was subsequently reacted with alcohols 41 and 44 to yield final compounds 46 and 47 as single stereoisomers. For amide 48, azide 9 was first reduced with a suspension of $10 \%$ palladium on carbon in methanol under an atmosphere of hydrogen gas to yield the intermediate amine which was immediately coupled to 45 using COMU and DIPEA in DMF to yield 48 as a single stereoisomer.

We next evaluated the cellular activity of 46-48 using our BromoTag-Brd2 knock-in cell line as described before (Figure 6A,C and Table 3). At this stage, we decided to quantify protein degradation over a wider eight-point concentration range from $10 \mu \mathrm{M}$ to $1 \mathrm{nM}$ for the purpose of obtaining more accurate $\mathrm{DC}_{50}$ and $D_{\max }$ values. Each compound displayed potent, highly selective, and near-complete $\left(D_{\max }>92 \%\right)$ degradation of BromoTag-Brd2 over the endogenous BET proteins. Both esters $46\left(\mathrm{DC}_{50} 13-15 \mathrm{nM}\right)$ and $47\left(\mathrm{DC}_{50} 1-3\right.$ $\mathrm{nM}$ ) showed more potent on-target degradation activity than amide 48 ( $\left.\mathrm{DC}_{50} 210-290 \mathrm{nM}\right)$, corresponding to $>17$-fold and $>81$-fold lower $\mathrm{DC}_{50}$, respectively (Figure 6A,C, Table 3, and see Supporting Information Figures S9-S14). As predicted, the enantiomerically pure compounds were found to be on average 5-fold more potent and displayed much more complete on-target degradation than when they were tested as diastereomeric mixtures ( $c f .23,25$, and 19, respectively, Figure 5 , Table 2). The large difference in potency displayed by the esters is exemplified by the pronounced hook effect at concentrations $>1 \mu \mathrm{M}$. From our recent work on amide-to- ester substitutions in related non-bumped BET PROTACs, the increase in potency observed is most likely due to the increase in cellular permeability as a result of increased lipophilicity from switching from an amide in 48 to an ester in $46 .^{30}$

To assess the speed at which our B\&H-PROTACs were able to fully deplete BromoTag-Brd2, we next ran a timedependent degradation assay by treating heterozygous BromoTag-Brd2 HEK293 cells with $500 \mathrm{nM} 46$ or 47 , or 1 $\mu \mathrm{M} 48$, and measuring BromoTag-Brd 2 protein levels over 36 $\mathrm{h}$ (Figure 6B,D, Table 3, and see Supporting Information Figures S15 and S16). Compound 46 proved to be the most rapid and most complete degrader that is able to completely degrade BromoTag-Brd 2 within $6 \mathrm{~h}$, yielding a protein half-life $\left(t_{1 / 2}\right)$ of just $40 \mathrm{~min}$. Compound 48 was a slightly slower degrader, inducing a protein $t_{1 / 2}$ of $113 \mathrm{~min}$ and was only able to degrade up to $\sim 80 \%$ of the protein in this experiment (Figure 6D). That is, the use of 48 twice the treatment concentration of 46 clearly demonstrates the more potent, faster, and profound activity of the ester-bumped PROTAC. The other ester compound $\mathbf{4 7}$ showed near-complete target degradation, similar to 46 , but not as fast $\left(t_{1 / 2}=142 \mathrm{~min}\right)$ when compared with 46, which combined with the residual, albeit minor off-target degradation of Brd3 at 100-1000 nM (Figure 6), led us to deprioritize 47. Together, the cellular data suggest 46 as the best degrader among the three evaluated as single stereoisomers.

To better understand the mode of action of our three B\&H-PROTACs, we next sought to investigate the ability of each compound to form a ternary complex between recombinantly purified $\mathrm{Brd} 4{ }^{\mathrm{BD} 2} \mathrm{~L} 387 \mathrm{~A}$ bromodomain protein and VHL. We therefore employed a competitive fluorescence polarization (FP) assay as previously published, ${ }^{17,31-33}$ where we displace a fluorescently labeled HIF- $1 \alpha$ peptide probe bound to VHL by titrating either the compound alone (for 
Scheme 3. Conjugation of Linkers to VHL Ligands ${ }^{a}$

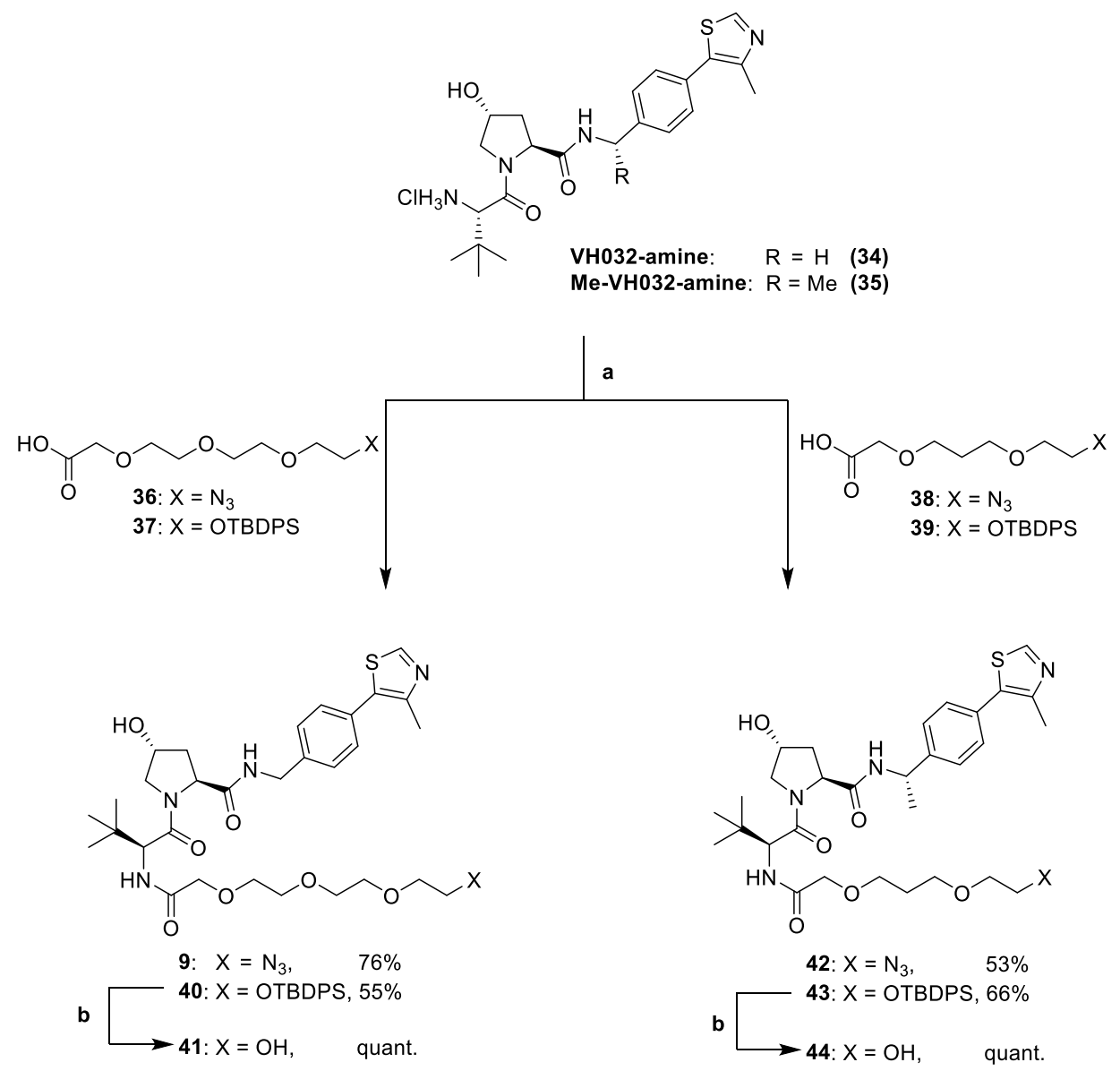

${ }^{a}$ Reaction conditions: (a) HATU, DIPEA, DMF, r.t., and $2 \mathrm{~h}$ and (b) TBAF, THF, r.t., and $6 \mathrm{~h}$.

binary binding) or by titrating the compound preincubated with $\mathrm{Brd} 4^{\mathrm{BD} 2} \mathrm{~L} 387 \mathrm{~A}$ protein (for ternary complex binding). The cooperativity $(\alpha)$ of ternary complex formation can then be determined $\left(\alpha=K_{\mathrm{d}}^{\text {binary }} / K_{\mathrm{d}}^{\text {ternary }}\right)$ (Figure 7$)$. A ternary complex is said to have positive or negative cooperativity when $\alpha>1$ or $\alpha<1$, respectively, and not cooperative when $\alpha$ $=1$. PROTACs 46,47 , and 48 had equipotent ternary binding affinity $\left(K_{\mathrm{d}}=11,12\right.$, and $9 \mathrm{nM}$, respectively), with MZ1-based 46 and $\mathbf{4 8}$ giving the most cooperative ternary complexes $(\alpha=$ 11.1 and 10.9, respectively). ARV-771-based 47 formed the least cooperative ternary complex $(\alpha=3.6$, Figure $7 \mathrm{~B})$ due to its $2-3$ fold greater binary affinity to VHL $\left(K_{d}=45 \mathrm{nM}\right.$ for 47 , compared to $K_{\mathrm{d}}=125$ and $102 \mathrm{nM}$ for 46 and 48, respectively). This loss in ternary complex cooperativity and stability is likely contributing to the slower rates of degradation observed, consistent with the previous findings with BET PROTACs. ${ }^{17,23,34}$

With all this biological data taken together, we selected 46 as our best B\&H-PROTAC and decided to take this forward for further biological evaluation.

2.6. Further Biological and Mechanistic Characterization of AGB1. Having established AGB1 (46) as the best potent and selective degrader compound for our BromoTag system, we next sought to further characterize its mechanism of action as expected for this compound class. To demonstrate that the on-target degradation activity of $\mathbf{4 6}$ is mechanistically due to its PROTAC mode of action, we performed pharmacological competition experiments (Figure 8A, see
Supporting Information Figure S17). To demonstrate VHL and proteasome dependency, we pretreated with the NAE1 inhibitor MLN4924, which inhibits neddylation of cullin $2,{ }^{35}$ with the VHL inhibitor $\mathrm{VH} 298,{ }^{36}$ and with the proteasome inhibitor MG132. ${ }^{37}$ In addition, to demonstrate that the ontarget activity on BromoTag-Brd2 is due to the recruitment of the BromoTag, we pretreated with ET-JQ1-OMe, which binds with high affinity to the $\mathrm{Brd} 4^{\mathrm{BD} 2 \mathrm{~L} 387 \mathrm{~A}}$ variant $\left(K_{\mathrm{d}}=65 \mathrm{nM}\right)$ but exhibits undetectable binding to the wild-type domain. ${ }^{21}$ In this experiment, we separately exposed our heterozygous BromoTag-Brd2 HEK293 cells to the different inhibitors for a short $1 \mathrm{~h}$ prior to subsequent treatment with $200 \mathrm{nM} 46$ before continuing treatment for a further $3 \mathrm{~h}$ to minimize potential confounding effects due to inhibitor cytotoxicity. As expected, the on-target degradation activity by 46 was completely abrogated upon pretreatments with MLN4924 or VH298, demonstrating dependency on CRL2 ${ }^{\mathrm{VHL}}$ activity (Figure $8 \mathrm{~A}$ and see Supporting Information Figure S17). The cellular activity of MLN4924 and VH298 in this experiment was confirmed by observing significant accumulation of HIF- $1 \alpha$ and blockade of Cul2 neddylation upon MLN4924 treatment. The on-target degradation activity was shown to be proteasome-dependent as it was blocked upon pretreatment with MG132. A similar outcome was also seen from the pretreatment with ET-JQ1-OMe (Figure 8A and see Supporting Information Figure S17), confirming that the ontarget degradation is exquisitely driven by target engagement with the BromoTag and not contributed by potentially 
Scheme 4. Synthesis of JQ1-Based B\&H-PROTACs as Mixtures of Two Diastereomers ${ }^{a}$

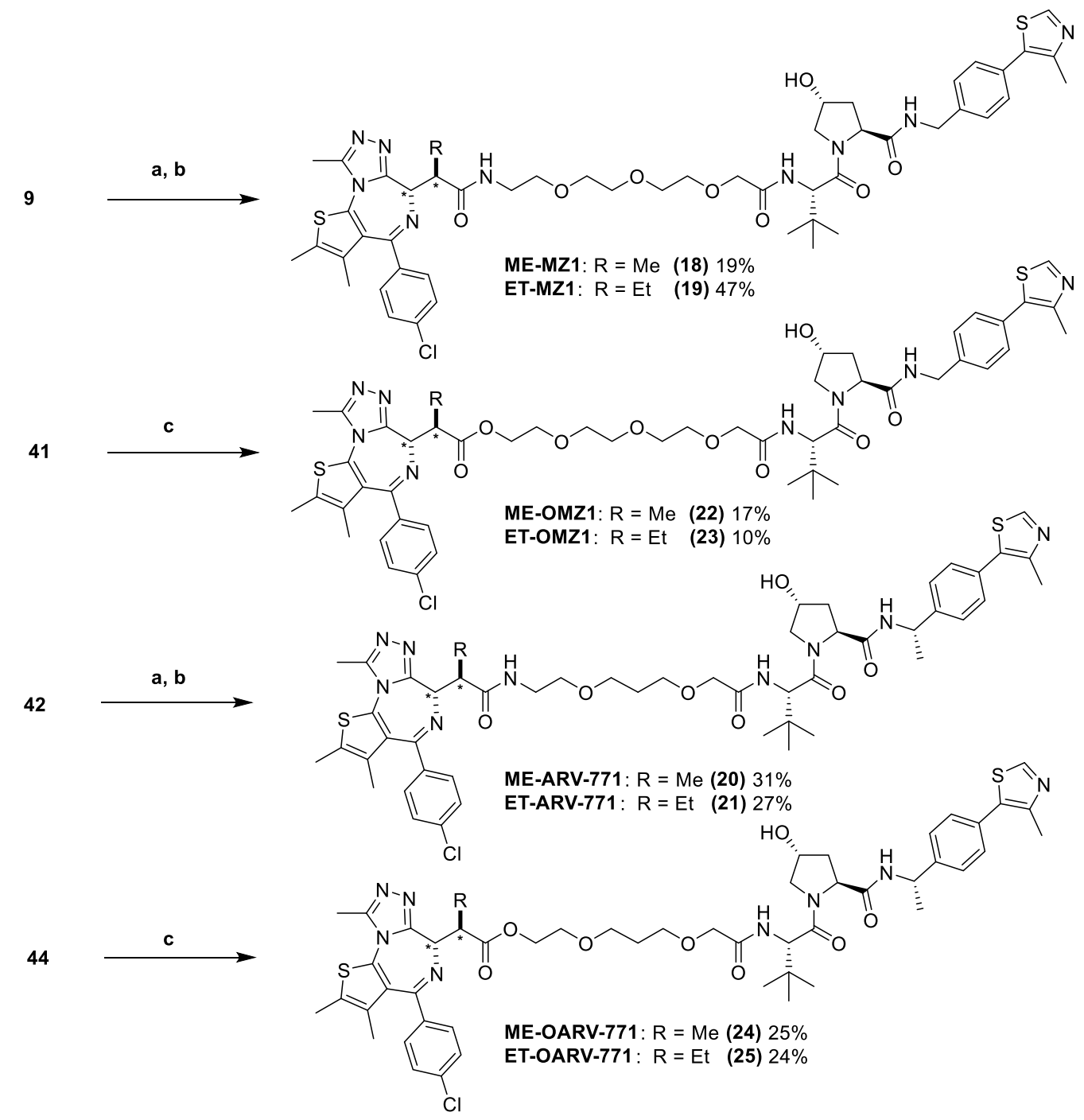

${ }^{a}$ Reaction conditions: (a) 10\% Pd/C, $\mathrm{H}_{2}, \mathrm{MeOH}$, r.t., and 3 h; (b) bumped JQ1 acid (32 or 33), COMU, DIPEA, THF, r.t., and 4 h; and (c) bumped JQ1 acid (32 or 33), EDC.HCl, DMAP, THF, r.t., and $16 \mathrm{~h}$. * indicates relative configuration at the specified stereogenic centers in the molecule.

adventitious weaker recruitment of the wild-type bromodomains of the endogenous $\mathrm{Brd} 2$ protein.

We next sought to monitor the duration of the on-target degradation activity of 46 using washout experiments. BromoTag-Brd2 HEK293 cells were treated with $200 \mathrm{nM} 46$ for $3 \mathrm{~h}$ and rinsed twice with phosphate-buffered saline (PBS), and fresh media were replenished without PROTAC. Following complete depletion after $3 \mathrm{~h}$, the protein levels of BromoTag-Brd2 were shown to recover $24 \mathrm{~h}$ after washout (Figure 8B and see Supporting Information Figure S18). This effect was in stark contrast to the complete and durable ontarget degradation for up to $72 \mathrm{~h}$ without washout. This result confirms the reversible nature of our BromoTag system. Noticeably, the Brd2 expression begins to decline $24 \mathrm{~h}$ after recovery, possibly reflecting the long-term regulation of $\mathrm{Brd} 2$ protein levels.

To qualify our degrader 46 as a suitable chemical probe for cellular biological investigation, we considered it important to assess potential cytotoxicity that might confound biological effects and responses and mask the desired on-target pharmacology. To this end, we elected as probe criteria that the compound does not exhibit any cytotoxicity at around and up to 10-fold higher than the concentrations at which it is to be used in cells. The remarkable selectivity and lack of off-target BET degradation activity of 46 encouraged us that the compound should not be cytotoxic, yet we decided to test this in the parent HEK293 cells, as well as more BET-sensitive MV4-11 and 22RV1 cell lines. To enable a suitable control to discount any potential non-degrading off-target engagement activity, we synthesized compound cis-AGB1 (52) bearing the cis- instead of trans-hydroxyproline group to abrogate binding to VHL (Scheme 6), a well-established strategy to yield negative non-degrading control compounds. ${ }^{14}$ To monitor cell viability, HEK293, MV-4-11, and 22RV1 cells were plated in a 96-well plate format and treated with vehicle control (DMSO), 46, its non-degrading control (52), and their non-bumped control compounds MZ1 and cis-MZ1, as well as the positive control cytotoxic agent staurosporine, in a dose-dependent manner and up to $10 \mu \mathrm{M}$. Cellular ATP levels as a proxy of viable cells were then measured using a CellTiter-Glo 2.0 cell 


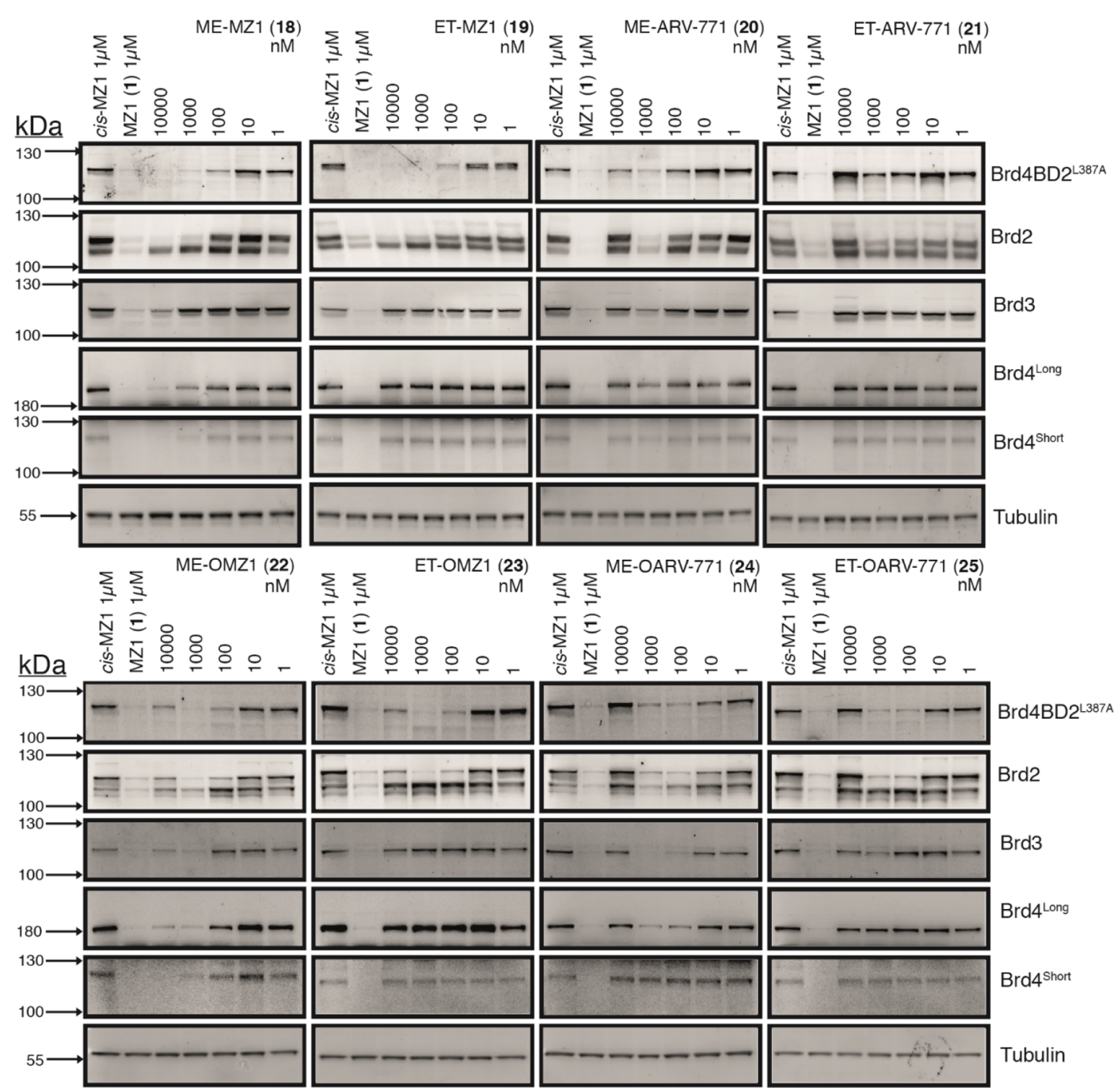

Figure 5. Biological evaluation of second-generation B\&H-PROTACs in BromoTag-Brd2 HEK293 cells. Western blot data for BET protein levels monitored from $10 \mu \mathrm{M}$ to $1 \mathrm{nM}$ compound treatment over $6 \mathrm{~h}$ in heterozygous BromoTag-Brd2 HEK293 cells. Bands are normalized to tubulin and negative control (cis-MZ1) to derive $\mathrm{DC}_{50}$ values that enable the rank order of each PROTAC.

Table 2. Quantification of the Degradation Profile of Second-Generation B\&H-PROTACs against BromoTagged-Brd2 via Two Different Antibodies (Ab)

\begin{tabular}{lccccc} 
& \multicolumn{2}{c}{$\mathrm{Ab}: \mathrm{Brd}^{2}{ }^{\mathrm{BD} 2}$ L387A } & & \multicolumn{2}{c}{$\mathrm{Ab}: \mathrm{Brd} 2$} \\
\cline { 2 - 3 } \cline { 5 - 6 } \multicolumn{1}{c}{ compound } & $\mathrm{pDC}_{50}{ }^{a}$ & $D_{\max }(\%)$ & & $\mathrm{pDC}_{50}{ }^{a}$ & $D_{\max }(\%)$ \\
ME-MZ1 (18) & $6.8 \pm 0.1$ & 90 & & $7.0 \pm 0.2$ & 92 \\
ET-MZ1 (19) & $6.6 \pm 0.6$ & 76 & & $6.5 \pm 0.2$ & 80 \\
ME-ARV-771 (20) & $6.5 \pm 0.4$ & 70 & & $6.4 \pm 0.6$ & 60 \\
ET-ARV-771 (21) & $6.1 \pm 0.3$ & 69 & & $5.7 \pm 1.8$ & 51 \\
ME-OMZ1 (22) & $7.1 \pm \mathrm{NA}$ & 94 & & $7.7 \pm 0.1$ & 96 \\
ET-OMZ1 (23) & $7.1 \pm \mathrm{NA}$ & 90 & & $7.9 \pm 0.2$ & 96 \\
ME-OARV-771 (24) & $8.0 \pm \mathrm{NA}$ & 91 & & $8.3 \pm 0.1$ & 91 \\
ET-OARV-771 (25) & $7.9 \pm 0.2$ & 90 & & $7.8 \pm 0.3$ & 85
\end{tabular}

${ }^{a}$ Calculated as mean $( \pm$ S.E) from three independent biological experiments.

viability assay (Figure 8C). Reassuringly, and as expected, 46 showed lack of cytotoxicity up to high concentrations of 1-10 $\mu \mathrm{M}$ in all the three cell lines. The remarkable sparing of offtarget degradation of endogenous BET proteins by 46 is starkly evidenced by comparing it with $\mathrm{MZ1}\left(\mathrm{EC}_{50}\right.$ of $\left.\sim 20 \mathrm{nM}\right)$ in the highly BET-sensitive MV-4-11 cells. Together, this data qualifies $\mathbf{4 6}$ as a mechanistically clean and bona fide BromoTag degrader for cellular investigation.

After demonstrating that 46 and 52 are non-toxic even in BET-sensitive cell lines, we next sought to evaluate their cellular selectivity at the proteome-wide level. To do this, we subjected our heterozygous BromoTag-Brd2 HEK293 cell line to a $1 \mu \mathrm{M}$ treatment of 46 , its non-degrading control 52 , or vehicle (DMSO) for $2 \mathrm{~h}$ prior to harvest. The harvested lysate was then subjected to multiplexed tandem mass tag (TMT) labeling mass spectrometry to enable quantitative and unbiased analysis of protein levels in each condition. Among the 6621 proteins quantified from this analysis, only $\mathrm{Brd} 2$ was shown to be significantly degraded upon $1 \mu \mathrm{M}$ treatment with 46 . No significant degradation was observed for any of the 6621 proteins upon treatment with $1 \mu \mathrm{M}$ of $\mathbf{5 2}$ (Figure 9 and see Supporting Information Figure S19). Together, this data further confirms the exquisite selectivity of compound 46 for the hole-bearing BromoTag over not only wild-type BET proteins but also the wider cellular proteome more broadly, further establishing the BromoTag as a utilizable approach for the highly tailored and selective cellular investigation of target proteins. 
Scheme 5. Synthesis of Enantiomerically Pure AGB1, AGB2, and AGB3 ${ }^{a}$

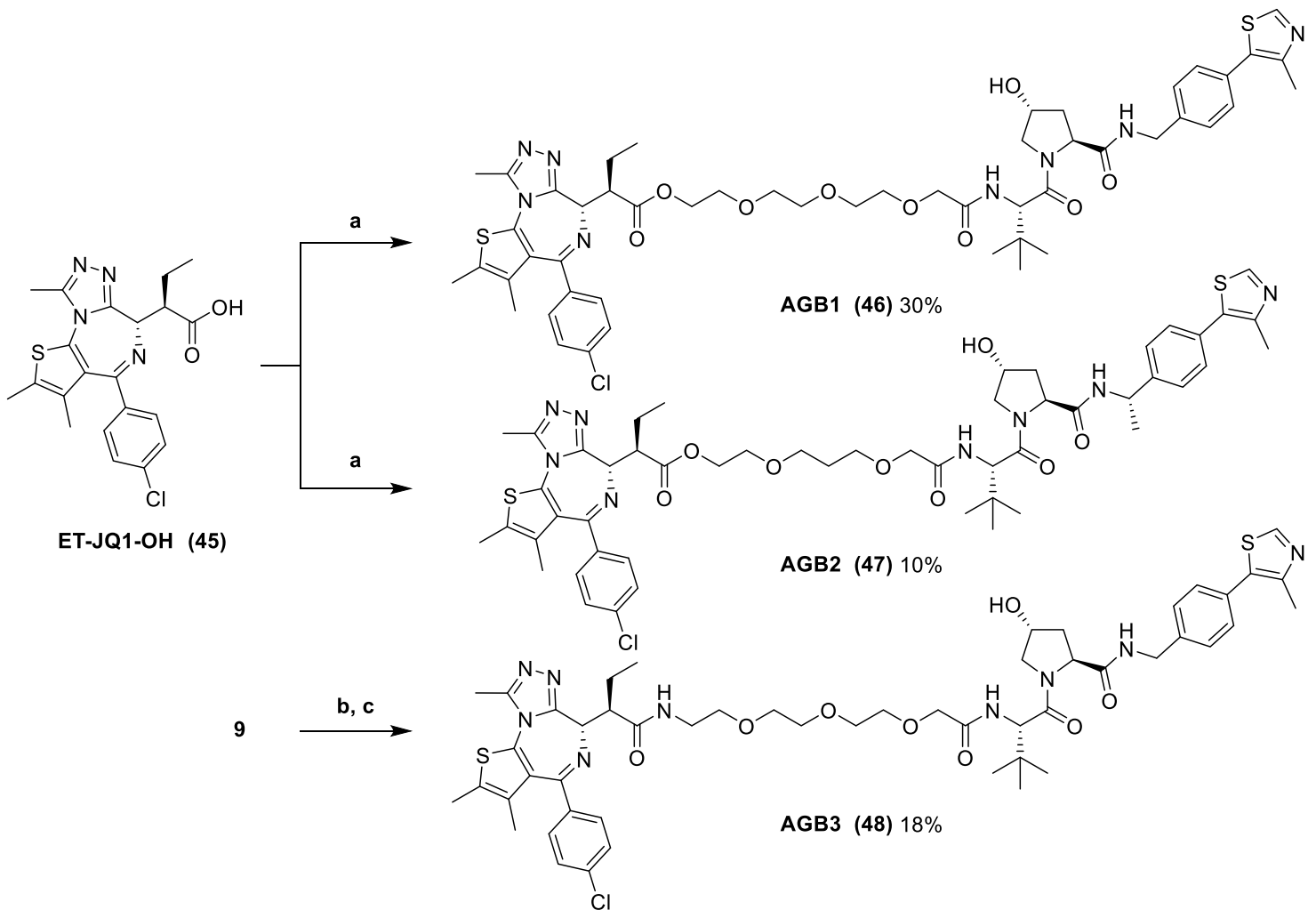

${ }^{a}$ Reaction conditions: (a) (i) $\mathrm{SOCl}_{2}$, DCM, r.t., and 3 h; (ii) 41 or 44, DCM, r.t., and 16 h; (b) $10 \% \mathrm{Pd} / \mathrm{C}, \mathrm{H}_{2}$, $\mathrm{MeOH}$, r.t., and 3 h; and (c) 45 , COMU, DIPEA, DMF, r.t., and $2 \mathrm{~h}$.

To qualify 46 as not only an all-cellular but also as an in vivo suitable degrader probe, we next evaluated the plasma stability of 46 by incubating in mouse plasma at $37^{\circ} \mathrm{C}$ and measuring the levels of 46 remaining at several time points over $1 \mathrm{~h}$ (Figure 10A). 46 showed excellent plasma stability with no significant changes to levels of 46 throughout the experiment. Finally, to further qualify $\mathbf{4 6}$ as appropriate for in vivo studies, we assessed its pharmacokinetic (PK) profile in mice (Figure $10 \mathrm{~B}$ and Tables 4 and 5). 46 was shown to have good PK profiles in mice for both intravenous (IV) (Table 4) and subcutaneous (SC) (Table 5) $5 \mathrm{mg} / \mathrm{kg}$ injections. 46 has comparable PK profiles as seen for parent compound MZ1 (1) with a relatively low clearance rate (CL) of $47.2 \mathrm{~mL} / \mathrm{min} / \mathrm{kg}$ and good half-lives $\left(T_{1 / 2}\right)$ of 1.49 and $1.65 \mathrm{~h}$ in IV and SC, respectively (compared with 1.05 and $2.95 \mathrm{~h}$ for $\mathbf{1}$ ) (Tables 4 and 5). ${ }^{38}$ Strikingly, 46 was able to maintain a plasma concentration above its BromoTag-Brd2 $\mathrm{DC}_{50,6 \mathrm{~h}}$ of $\sim 13 \mathrm{nM}$ when dosed at $5 \mathrm{mg} / \mathrm{kg}$ for $\sim 4 \mathrm{~h} \mathrm{IV}$ injection and for $>8 \mathrm{~h} \mathrm{SC}$ injection (Figure 9), making it suitable for in vivo studies to assess the functional consequences of BromoTagged target protein degradation in genetically engineered mouse models.

\section{CONCLUSIONS AND FUTURE PERSPECTIVE}

Through a careful structural guided design, we have developed AGB1 (46) and qualified it as a fast, highly selective, and potent $\mathrm{B} \& \mathrm{H}-\mathrm{PROTAC}$ degrader for our new inducible degron system, BromoTag. We show that AGB1 (46) not only forms a strong, cooperative ternary complex between VHL and the BromoTag (Brd4 ${ }^{\mathrm{BD} 2 \mathrm{~L} 387 \mathrm{~A}}$ ) but also completely degrades BromoTagged target proteins with low nanomolar potency and exquisite selectivity over the native wild-type BET proteins at the proteome-wide level. We also show that AGB1 (46) is not cytotoxic in several cancer relevant cell lines, further exemplifying its superior selectivity over off-target endogenous BET proteins. AGB1 (46) has also shown excellent plasma stability and acceptable PKs for it to be suitable for later in vivo studies in mouse models. We therefore qualify AGB1 (46) and our new BromoTag system as a useful tool to probe biology. Demonstrated and optimized here through $\mathrm{N}$-terminal tagging of the target protein $\mathrm{Brd} 2$, future work will focus on exemplifying feasibility to use the BromoTag on multiple targets, including tagging proteins at the C-terminus as well, and applying the technology to address targeted biological questions in cells and in vivo. We envisage that the BromoTag could also be used in tandem with other inducible degrons such as dTAG, AID, or HaloPROTACs as an orthogonal system to individually or simultaneously deplete more than one protein at once.

During the preparation of this manuscript, a report came out online describing the development of XY-06-007, a compound that utilizes the same $B \& H-P R O T A C$ concept used to develop AGB1. ${ }^{39}$ Although AGB1 and XY-06-007 were not compared in the same assays, our data suggests that the MZ1like highly cooperative and stable ternary complex formed by AGB1 with VHL and our BromoTag underscores its fast, profound and selective tagged target protein degradation that is more significant with AGB1 than XY-06-007. In future, it will be interesting to compare the degradation potencies, kinetics, and potential for off-target degradation activity of the two compounds side-by-side against CRISPR-tagged target proteins expressed at the near-endogenous level, as shown here. Because XY-06-007 and AGB1 differ significantly both in the 


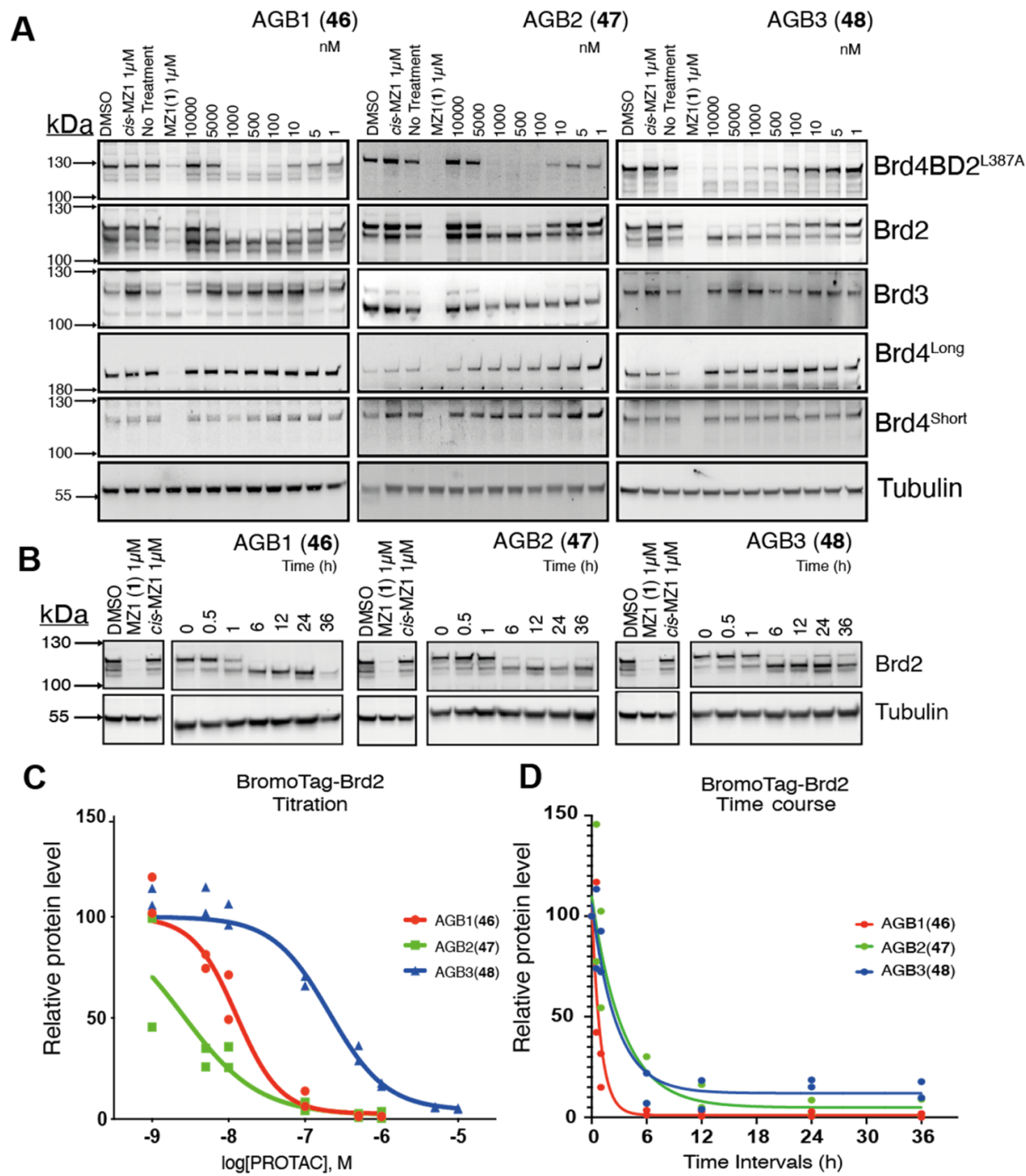

Figure 6. Biological evaluation of AGB1 (46), AGB2 (47), and AGB3 (48) in BromoTag-Brd2 HEK293 cells. (A) Western blot data for BET protein levels monitored from $10 \mu \mathrm{M}$ to $1 \mathrm{nM}$ compound treatment over $6 \mathrm{~h}$ in heterozygous BromoTag-Brd2 HEK293 cells. (B) Time course western blot data of Brd2 levels in heterozygous BromoTag-Brd2 HEK293 cells upon $500 \mathrm{nM}$ treatment of 46 and 47 and $1 \mu \mathrm{M}$ treatment of 48 over $36 \mathrm{~h}$. (C,D) Plots to calculate $(C) \mathrm{DC}_{50}$ and $(D) t_{1 / 2}$ values for compounds enabling determination that AGB1 is the best choice for further validation. Western blots from $(\mathrm{A}, \mathrm{B})$ were normalized to tubulin and compared to a vehicle control (DMSO) to derive $\mathrm{pDC}_{50}$ or $t_{1 / 2}$ values that enable rank order of each PROTAC.

\section{Table 3. Degradation Profile for AGB1, AGB2, and AGB3}

\begin{tabular}{lcrrrcr} 
& \multicolumn{2}{c}{$\mathrm{Ab}: \mathrm{Brd}^{4 \mathrm{BD} 2} \mathrm{L387 \textrm {A }}$} & & \multicolumn{3}{c}{$\mathrm{Ab}$ : BromoTag-Brd2 } \\
\cline { 2 - 3 } \cline { 5 - 6 } compound & $\mathrm{pDC}_{50}{ }^{a}$ & $\begin{array}{c}D_{\max } \\
(\%)\end{array}$ & & $\mathrm{pDC}_{50}{ }^{a}$ & $\begin{array}{l}D_{\max } \\
(\%)\end{array}$ & $t_{1 / 2}(\mathrm{~min})^{b}$ \\
AGB1 (46) & $7.8 \pm 0.2$ & 99 & & $7.9 \pm 0.1$ & 97 & $40 \pm 15$ \\
AGB2 (47) & $9.0 \pm 0.4$ & 100 & & $8.6 \pm 0.2$ & 98 & $142 \pm 13$ \\
AGB3 (48) & $6.5 \pm 0.3$ & 92 & & $6.7 \pm 0.1$ & 96 & $113 \pm 8$
\end{tabular}

${ }^{a}$ Calculated from the mean $( \pm$ S.E. $)$ of two independent repeats. ${ }^{b}$ Calculated from the mean $( \pm$ span $)$ of two independent repeats.

chemistry (I-BET762 rather than JQ1-based methyl rather than ethyl bump, respectively) and biology (CRBN- rather than VHL-based, Brd4 ${ }^{\mathrm{BD} 1 \mathrm{~L} 94 \mathrm{~V}}$ tag instead of $\mathrm{Brd} 4^{\mathrm{BD} 2 \mathrm{~L} 387 \mathrm{~A}}$, respectively), the two approaches can be highly complementary. Therefore, the work described herein and that of Nowak et $a .^{39}$ provide two distinct methods to induce degradation of bromodomain-tagged proteins, which add to the growing arsenal of inducible degron technologies available to study the effect and implications of rapid and highly selective degradation of a target protein.

\section{EXPERIMENTAL SECTION}

4.1. Chemistry. 4.1.1. Synthesis. Chemicals, commercially available, were purchased from Apollo Scientific, Sigma-Aldrich, Fluorochem, or Manchester Organics and used without any further purification. All reactions were carried out using anhydrous solvents. The reactions were monitored using either an Agilent Technologies 1200 series analytical high-performance liquid chromatograph (HPLC) connected to an Agilent Technologies 6130 quadrupole LC/MS containing an Agilent diode array detector and a Waters XBridge C18 column $(50 \mathrm{~mm} \times 2.1 \mathrm{~mm}$ and $3.5 \mu \mathrm{m}$ particle size $)$. The samples were eluted with a $3 \mathrm{~min}$ gradient of $5-95 \% \mathrm{MeCN} /$ water containing $0.1 \%$ formic acid at a flow rate of $0.7 \mathrm{~mL} / \mathrm{min}$ or a Shimadzu HPLC/MS 2020 with a photodiode array detector and a Hypersil Gold column $(1.9 \mu \mathrm{m} 50 \times 2.1 \mathrm{~mm})$. The samples were eluted with a $3 \mathrm{~min}$ gradient of $5-95 \% \mathrm{MeCN} /$ water containing $0.1 \%$ formic acid at a flow rate of $0.8 \mathrm{~mL} / \mathrm{min}$. The intermediates were purified by flash column chromatography using a Teledyne Isco 
A

A

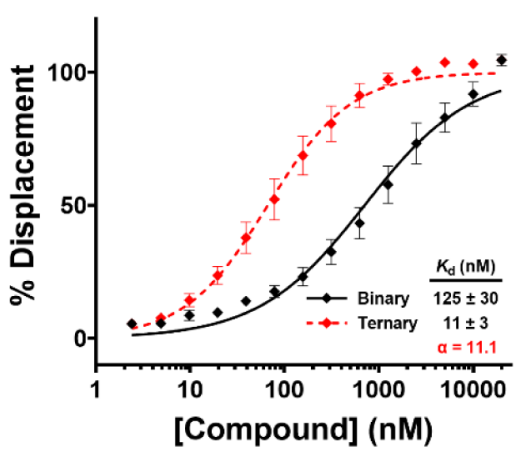

B

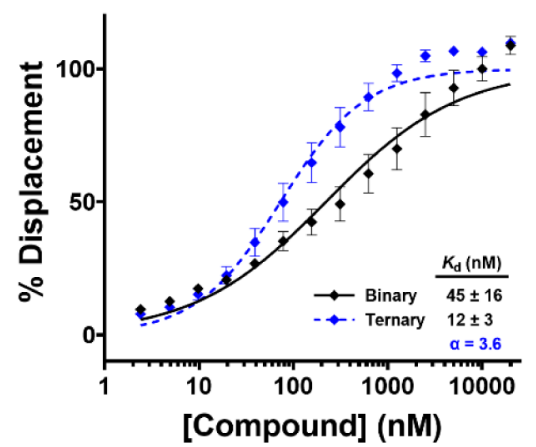

C

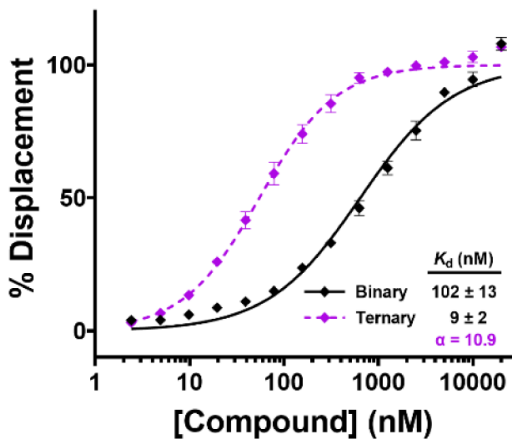

Figure 7. FP of B\&H-PROTAC binary and ternary complex binding. Binary and ternary complex formation FP data for 46 (A), 47 (B), and 48 (C) to VHL alone (black solid line) or preincubated with Brd4 ${ }^{\text {BD2 L387A }}$ to VHL (colored dashed line), respectively. Error bars and $K_{\mathrm{d}}$ values are mean ( \pm S.E.M.) from $N=4$ for binary and ternary binding to VHL. The left shift between the binary and ternary data indicates positive cooperativity. Cooperativity $(\alpha)$ calculated as a ratio of $K_{\mathrm{d}}^{\text {binary }} / K_{\mathrm{d}}^{\text {ternary }}$.

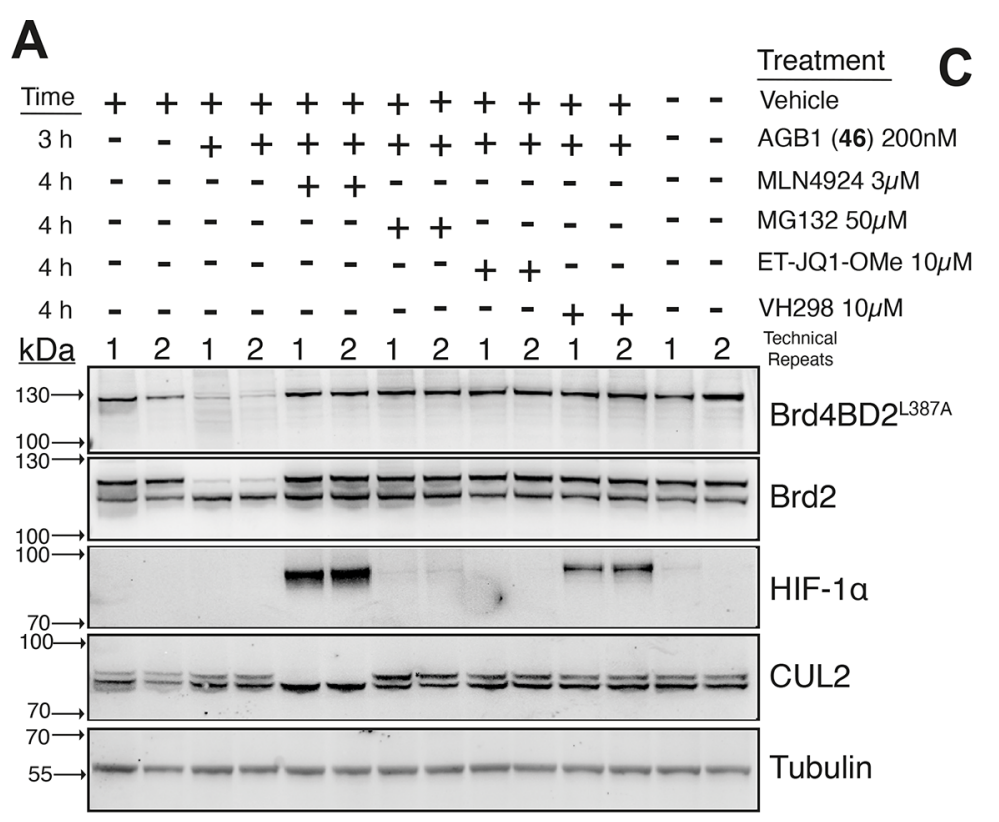

\section{B}

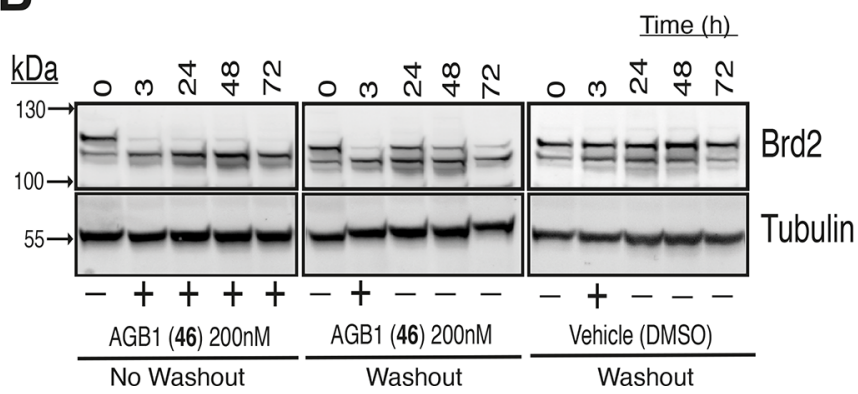

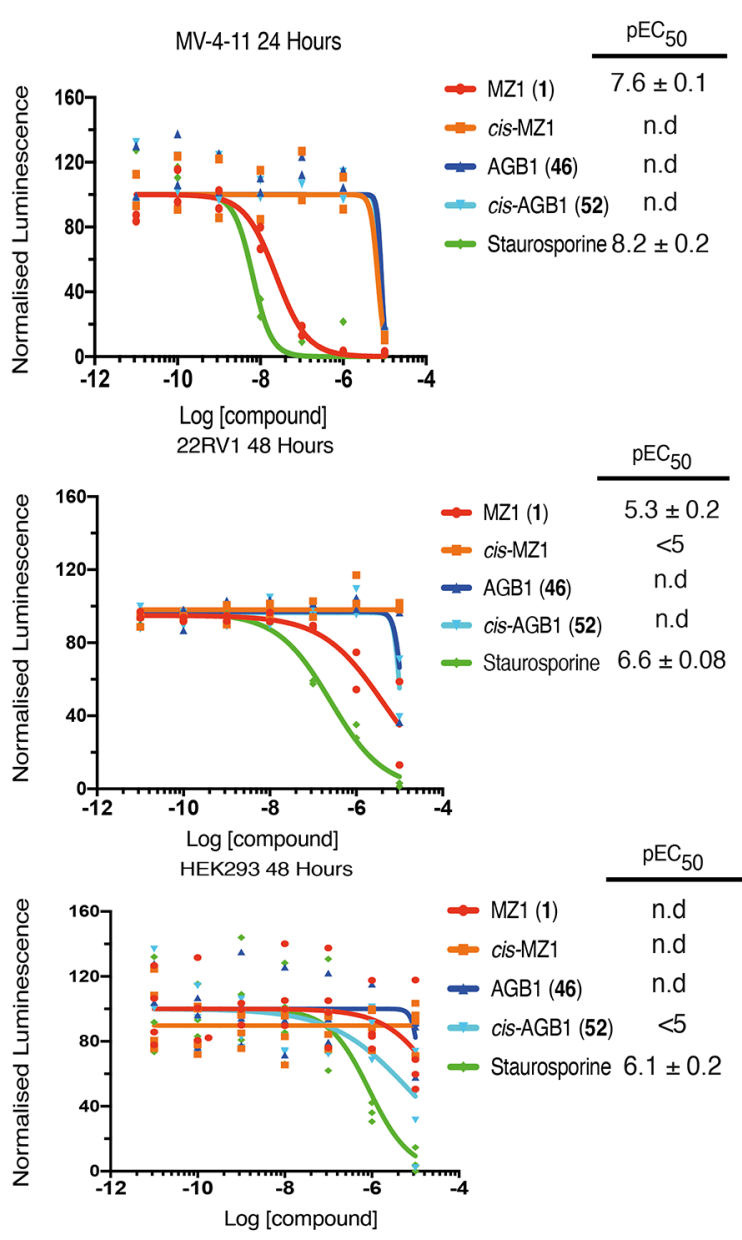

Figure 8. Cellular mechanistic characterization of AGB1 (46) degradation activity. (A) Western blot illustrating the on-target degradation activity of 46 is dependent on the activity of CRL2 ${ }^{\mathrm{VHL}}$ and proteasome and on BromoTag target engagement. BromoTag-Brd2 HEK293 cells were treated with $200 \mathrm{nM} 46(3 \mathrm{~h})$ following pretreatment $(1 \mathrm{~h})$ with the proteasome inhibitor MG132, neddylation inhibitor MLN4924, VHL inhibitor VH298, or BromoTag inhibitor ET-JQ1-OMe or DMSO vehicle. (B) Western blots demonstrating the recovery of BromoTag-Brd2 post-removal of $200 \mathrm{nM} 46$ after a $3 \mathrm{~h}$ treatment in heterozygous BromoTag-Brd2 HEK293 cells. Control experiments for no-wash and vehicle treatments are included. Bands are normalized to tubulin protein levels and compared to a vehicle control (DMSO) to quantify the final protein levels of BromoTag-Brd2. (C) Effect on antiproliferation of $\mathbf{4 6}$ compared to MZ1 and non-degrader controls 52 and cis-MZ1. Staurosporine was used as a positive control for cytotoxicity. MV-4-11, 22Rv1, and HEK293 cells were treated with varying concentrations of compound, and after 24, 48, and $48 \mathrm{~h}$, respectively, the cells were subjected to the Promega CellTiter-Glo cell viability assay. The $\mathrm{pEC}_{50}$ values $( \pm$ S.E.M $)$ are mean from $N=2$ for MV-4-11 and 22Rv1 cells and $N=3$ for HEK293 cells from data normalized from vehicle control (DMSO). 
Scheme 6. Synthesis of Negative Control cis-AGB1 (52) ${ }^{a}$<smiles>CN[C@H](C(=O)N1C[C@@H](O)CC1C(=O)NCc1ccc(-c2scnc2C)cc1)C(C)(C)C</smiles><smiles>CCC(C(=O)OCCOCCOCCOCC(=O)N[C@H](C(=O)N1C[C@H](O)C[C@H]1C(=O)NCc1ccc(-c2scnc2C)cc1)C(C)(C)C)[C@H]1N=C(c2ccc(Cl)cc2)c2c(sc(C)c2C)-n2c(C)nnc21</smiles>

${ }^{a}$ Reaction conditions: (a) 37, COMU, DIPEA, DMF, r.t., and 2 h; (b) TBAF, THF, r.t., and 6 h; and (c) (i) 45, SOCl, DCM, r.t., and 3 h and (ii) 51, DCM, r.t., and $16 \mathrm{~h}$.

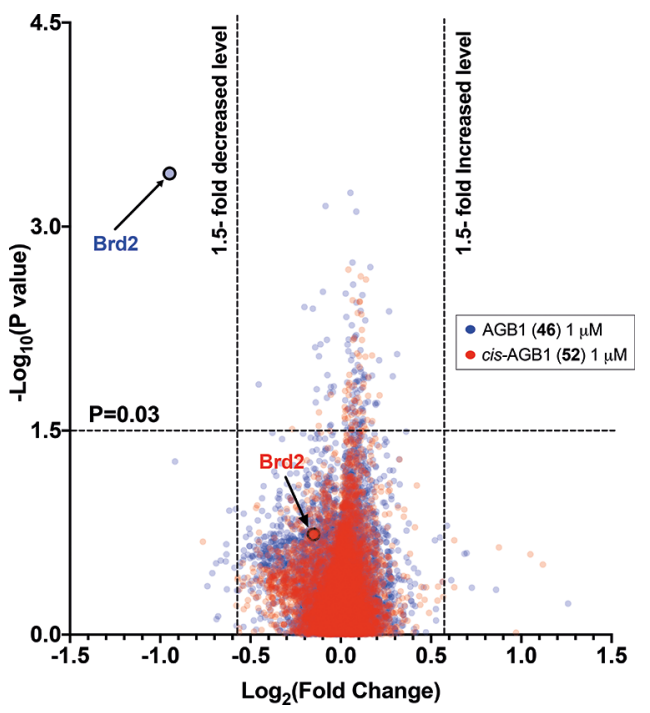

Figure 9. Proteomics of AGB1 (46) and cis-AGB1 (52) treated heterozygous BromoTag-Brd2 HEK293 cells. Scatterplot depicting the effect of 46 (blue) and 52 (red) treatment on the proteome of heterozygous BromoTag-Brd2 HEK293 cells treated with $1 \mu \mathrm{M}$ of compound for $2 \mathrm{~h}$. Brd2 expression is highlighted for both treatment conditions. The data plotted is $\log _{2}$ of the normalized fold change in abundance against $-\log _{10}$ of the $\mathrm{p}$ value per protein identified from TMT mass spectrometry analysis produced from three independent experiments.

CombiFlash Rf or Rf200i with Normal Phase RediSep Rf Disposable Columns or with Reverse Phase RediSep Rf Gold C18 Reusable Columns. Final compounds were purified by HPLC using a Gilson Preparative HPLC System equipped with a Waters X-Bridge C18 column $(100 \mathrm{~mm} \times 19 \mathrm{~mm}$ and $5 \mu \mathrm{m}$ particle size $)$ using a gradient from 5 to $95 \%$ of acetonitrile in water containing $0.1 \%$ formic acid or ammonia over $10 \mathrm{~min}$ at a flow rate of $25 \mathrm{~mL} / \mathrm{min}$ unless stated otherwise. Compound characterization using NMR was performed either on a Bruker 500 Ultrashield or on a Bruker Ascend 400 spectrometer. The proton $\left({ }^{1} \mathrm{H}\right)$ and carbon $\left({ }^{13} \mathrm{C}\right)$ reference solvents used are as follows: $d_{1}$-chloroform $-\mathrm{CDCl}_{3}[(\delta \mathrm{H}=7.26 \mathrm{ppm} / \delta \mathrm{C}=$ $77.15 \mathrm{ppm})]$ and $d_{4}-\mathrm{CD}_{3} \mathrm{OD}(\delta \mathrm{H}=3.31 \mathrm{ppm} / \delta \mathrm{C}=49.00 \mathrm{ppm})$.
Signal patterns are described as singlet $(\mathrm{s})$, doublet $(\mathrm{d})$, triplet $(\mathrm{t})$, quartet (q), quintet (quint.), multiplet (m), broad (br), or a combination of the listed splitting patterns. The coupling constants $(J)$ are measured in hertz $(\mathrm{Hz})$. The NMR spectra for all compounds were obtained using Bruker TopSpin 4.1.1. High-resolution mass spectrometry (HRMS) was performed on a Bruker MicrOTOF II focus ESI Mass Spectrometer connected in parallel to a Dionex Ultimate 3000 RSLC system with a diode array detector and a Waters XBridge C18 column $(50 \mathrm{~mm} \times 2.1$ and $3.5 \mu \mathrm{m}$ particle size $)$. The samples were eluted with a 6 min gradient of 5-95\% acetonitrile/ water containing $0.1 \%$ formic acid at a flow rate of $0.6 \mathrm{~mL} / \mathrm{min}$. All compounds are $>95 \%$ pure by HPLC.

4.1.2. General Procedure A. Azide 9 (synthesized according to the literature $\left.{ }^{14}\right)$ ( 1 equiv) was dissolved in $\mathrm{MeOH}(125 \mathrm{~mL} / \mathrm{mmol})$. A catalytic amount of $10 \mathrm{wt} \% \mathrm{Pd} / \mathrm{C}$ was added, and the reaction was stirred under an atmosphere of $\mathrm{H}_{2}$ for $3 \mathrm{~h}$. The reaction mixture was then filtered through PTFE syringe filters and evaporated to dryness to obtain the desired amine quantitative yields. The resulting amine ( 1 equiv) was added to a solution of acid ( 1 equiv), HATU ( 1 equiv), HOAt ( 1 equiv), and DIPEA ( 3 equiv) in DCM or DMF $(2 \mathrm{~mL})$ and left to stir at r.t. for $18 \mathrm{~h}$. This was then purified by HPLC.

4.1.3. General Procedure B. Azides (1 equiv) were dissolved in $\mathrm{MeOH}(125 \mathrm{~mL} / \mathrm{mmol})$. A catalytic amount of $10 \mathrm{wt} \% \mathrm{Pd} / \mathrm{C}$ was added, and the reaction was stirred under an atmosphere of $\mathrm{H}_{2}$ for 3 $h$. The reaction mixture was then filtered through PTFE syringe filters and evaporated to dryness to obtain the desired amines' quantitative yields. The resulting amines were added to a solution of alkylated JQ1 acids ( 1 equiv), COMU ( 1.5 equiv), and DIPEA ( 3 equiv) in THF ( 8 $\mathrm{mL} / \mathrm{mmol}$ ) and stirred at r.t. for $4 \mathrm{~h}$. The mixtures were then concentrated in vacuo, and the residues were purified by HPLC using a linear gradient of $5-95 \% \mathrm{MeCN}$ in $0.1 \%$ formic acid in water over 12 min to afford amides as mixtures of two diastereomers.

4.1.4. General Procedure C. Alkylated JQ1 acids (1 equiv) and $\mathrm{EDC} \cdot \mathrm{HCl}$ (2 equiv) were dissolved in THF $(15 \mathrm{~mL} / \mathrm{mmol})$ and stirred at r.t. for 5 min. DMAP ( 3 eq) and alcohols (2 equiv) were then added, and the reaction was left to stir at r.t. for $16 \mathrm{~h}$. The mixtures were then concentrated in vacuo, and the residues were purified by HPLC using a linear gradient of $5-95 \% \mathrm{MeCN}$ in $0.1 \%$ formic acid in water over $12 \mathrm{~min}$ to afford amides as mixtures of two diastereomers.

4.1.5. General Procedure D. Compound $29(120 \mathrm{mg}, 0.29 \mathrm{mmol})$ was dissolved in THF $(5.2 \mathrm{~mL})$ and cooled to $-78^{\circ} \mathrm{C}$. A solution of $0.5 \mathrm{M}$ KHMDS in toluene ( $812 \mu \mathrm{L}, 0.41 \mathrm{mmol})$ was added dropwise, 
A

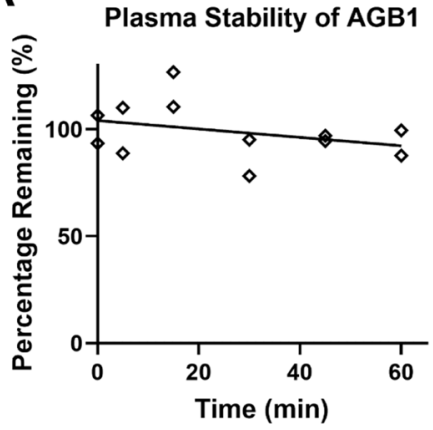

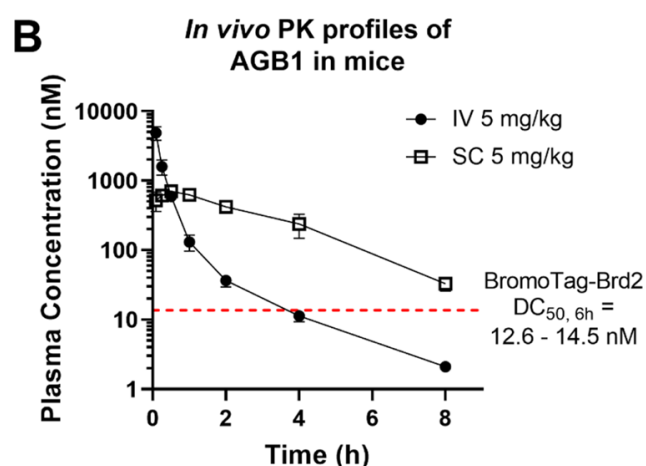

Figure 10. Plasma stability and in vivo PK studies of AGB1 (46) in mice. (A) Percentage of 46 remaining after 0, 5, 15, 30, 45, and 60 min in mouse plasma at $37^{\circ} \mathrm{C}$, normalized to 0 min time point, with two independent repeats per time point. (B) Male C57BL/6 mice were treated with a single $5 \mathrm{mg} / \mathrm{kg}$ dose of 46 by either IV (black dots) or SC (hollow squares) injection, and the blood plasma concentration of 46 was measured at seven time points. Data is mean $( \pm$ S.D. $)$ from three independent repeats at each time point. The red dashed line indicates the $\mathrm{DC}_{50,6 \mathrm{~h}}$ of 46 for degrading BromoTag-Brd2.

Table 4. PK Study of AGB1 in Mice with IV Dosing Compared to MZ1

\begin{tabular}{ccccccc} 
& \multicolumn{5}{c}{$\mathrm{IV}(5 \mathrm{mg} / \mathrm{kg})$} \\
\cline { 2 - 7 } compound & $\mathrm{CL}(\mathrm{mL} / \mathrm{min} / \mathrm{kg})$ & $V_{\mathrm{ss}}(\mathrm{L} / \mathrm{kg})$ & $T_{1 / 2}(\mathrm{~h})$ & $\mathrm{AUC}_{\text {last }}(\mu \mathrm{M} \cdot \mathrm{h})$ & $\mathrm{AUC}_{\text {inf }}(\mu \mathrm{M} \cdot \mathrm{h})$ & $\mathrm{MRT}_{\text {inf }}(\mathrm{h})$ \\
$\mathrm{AGB1}(\mathbf{4 6})$ & 47.2 & 1.10 & 1.49 & 1.71 & 1.72 & 0.390 \\
$\mathrm{MZ1}(\mathbf{1})^{a}$ & 19.7 & 0.38 & 1.04 & & 4.51 & 0.340
\end{tabular}

${ }^{a}$ Values obtained from ref 38.

Table 5. PK Study of AGB1 in Mice with SC Dosing Compared to MZ1

\begin{tabular}{ccccccc} 
& \multicolumn{6}{c}{$\mathrm{SC}(5 \mathrm{mg} / \mathrm{kg})$} \\
\cline { 2 - 7 } & $T_{\max }$ & $\begin{array}{c}C_{\max } \\
(\mu)\end{array}$ & $\begin{array}{c}T_{1 / 2} \\
(\mathrm{~h})\end{array}$ & $\begin{array}{c}\mathrm{AUC}_{\text {last }} \\
(\mu \mathrm{M} \cdot \mathrm{h})\end{array}$ & $\begin{array}{c}\mathrm{AUC}_{\text {inf }} \\
(\mu ; \mathrm{M} \cdot \mathrm{h})\end{array}$ & $F(\%)$ \\
$\begin{array}{c}\text { AGB1 } \\
(46)\end{array}$ & 0.500 & 0.700 & 1.65 & 2.33 & 2.40 & 140 \\
$\left.\mathrm{MZ1}^{(1}\right)^{a}$ & 0.500 & 2.07 & 2.95 & & 3.76 & 83
\end{tabular}

${ }^{a}$ Values obtained from ref 38.

and the reaction was left to stir at $-78{ }^{\circ} \mathrm{C}$ for $1 \mathrm{~h}$. Alkyl iodide $(0.41$ $\mathrm{mmol}$ ) was then added, and the reaction was stirred for a further 10 $\min$ at $-78{ }^{\circ} \mathrm{C}$ before warming to r.t. and leaving to stir for $16 \mathrm{~h}$. The mixture was then concentrated in vacuo and purified by HPLC using a linear gradient of $30-70 \% \mathrm{MeCN}$ in $0.1 \%$ formic acid in water over $12 \mathrm{~min}$ to afford alkylated JQ1-OMe derivatives.

4.1.6. General Procedure E. $(2 S, 3 S)$ Diastereomers (1 equiv) and $\mathrm{NaOMe}$ (10 equiv) were dissolved in $\mathrm{MeOH}(60 \mathrm{~mL} / \mathrm{mmol})$ in a closed, $\mathrm{N}_{2}$-purged, microwave vial and heated to $120{ }^{\circ} \mathrm{C}$ under microwave irradiation for $40 \mathrm{~min}$. The reaction was stirred at $60{ }^{\circ} \mathrm{C}$ before acidifying with a few drops of $\mathrm{AcOH}$. The reaction was then cooled to r.t. and concentrated in vacuo. The residues were purified by HPLC using a linear gradient of $30-70 \% \mathrm{MeCN}$ in $0.1 \%$ formic acid in water over $12 \mathrm{~min}$.

4.1.7. General Procedure F. ET-JQ1-OH (45, synthesized according to the literature ${ }^{21}$ ) (1 equiv) was dissolved in DCM (9 $\mathrm{mL} / \mathrm{mmol}$ ) under an atmosphere of $\mathrm{N}_{2}$. Thionyl chloride (15 equiv) was then added, the reaction was left to stir at r.t. for $3 \mathrm{~h}$, and conversion to acid chloride was monitored by LCMS in $\mathrm{MeOH}$ [monitor through the mass of methyl ester $(\sim 443)]$. The mixture was evaporated to dryness to afford the acid chloride intermediate quantitatively. Alcohols (1 equiv) were dissolved in DCM $(9 \mathrm{~mL} /$ $\mathrm{mmol}$ ) and added to the acid chloride. This was left to stir at r.t. for $16 \mathrm{~h}$. The mixtures were then concentrated in vacuo and purified.

4.1.8. (2S,4R)-1-((2S)-2-(tert-Butyl)-17-(6-(4-chlorophenyl)-8-methoxy-1-methyl-4H-benzo[f][1,2,4]triazolo[4,3-a][1,4]diazepin-4yl)-4,16-dioxo-6,9,12-trioxa-3,15-diazaheptadecanoyl)-4-hydroxy$\mathrm{N}$-(4-(4-methylthiazol-5-yl)benzyl)pyrrolidine-2-carboxamide (MZP-15) (14). Following general procedure $\mathrm{A}$, compound 14 was obtained using acid 10 (synthesized according to the literature ${ }^{40}$ ) without HOAt in DCM and purified by HPLC using a linear gradient of $5-95 \% \mathrm{MeCN}$ in $0.1 \%$ formic acid in water over $12 \mathrm{~min}$ to afford 14 as a mixture of two diastereomers. Yield: $16.5 \mathrm{mg}$ (47\%); ${ }^{1} \mathrm{H}$ NMR $\left(400 \mathrm{MHz}, \mathrm{CDCl}_{3}\right): \delta 8.70(\mathrm{~s}, 1 \mathrm{H}), 8.63-8.61(\mathrm{~m}, 1 \mathrm{H}), 8.31-8.28$ (m, $1 \mathrm{H}), 8.10-8.03(\mathrm{~m}, 1 \mathrm{H}), 7.52-7.45(\mathrm{~m}, 3 \mathrm{H}), 7.41-7.28(\mathrm{~m}$, $8 \mathrm{H}), 7.20-7.16(\mathrm{~m}, 1 \mathrm{H}), 6.86-6.84(\mathrm{~m}, 1 \mathrm{H}), 4.87-4.81(\mathrm{~m}, 1 \mathrm{H})$, $4.71-4.63(\mathrm{~m}, 2 \mathrm{H}), 4.57-4.48(\mathrm{~m}, 2 \mathrm{H}), 4.41-4.28(\mathrm{~m}, 2 \mathrm{H}), 4.22-$ $4.06(\mathrm{~m}, 3 \mathrm{H}), 3.78(\mathrm{~s}, 3 \mathrm{H}), 2.57-2.54(\mathrm{~m}, 3 \mathrm{H}), 2.51-2.49(\mathrm{~m}, 3 \mathrm{H})$, 2.46-2.35 (m, 1H), 2.27-2.20 (m, 1H), 1.01-0.99 ppm (m, 9H); ${ }^{13} \mathrm{C}$ NMR (101 MHz, $\mathrm{CDCl}_{3}$ ): $\delta 171.7,171.5,171.3,171.1,171.04$, $171.01,170.9,170.7,166.6,166.4,158.3,156.74,156.70,150.6,150.3$, 148.3 , 138.7, 138.6, 137.2, 137.1, 137.0, 131.1, 131.0, 130.62, 130.55, $130.4,130.3,129.51,129.47,129.2,128.7,128.6,128.2,128.1,126.2$, $124.95,124.91,120.3,118.2,118.1,116.0,71.7,71.2,70.9,70.8,70.6$, $70.5,70.4,70.3,70.22,70.15,59.2,59.1,57.5,57.3,56.9,56.0,53.6$, $53.5,43.2,40.0,39.9,38.1,38.0,36.9,36.7,35.8,35.6,26.6,16.0$, 12.11, 12.07; HRMS $m / z$ : calcd for $\mathrm{C}_{50} \mathrm{H}_{61} \mathrm{ClN}_{9} \mathrm{O}_{9} \mathrm{~S}[\mathrm{M}+\mathrm{H}]^{+}$, 998.3996; found, 998.3996.

4.1.9. $(2 S, 4 R)-1-\left(\left(2 S, 17 R^{*}\right)-2\right.$-(tert-Butyl)-17-((S*)-6-(4-chlorophenyl)-8-methoxy-1-methyl-4H-benzo[f][1,2,4]triazolo[4,3-a][1,4]diazepin-4-yl)-4, 16-dioxo-6,9,12-trioxa-3,15-diazanonadecanoyl)-4-hydroxy-N-(4-(4-methylthiazol-5-yl)benzyl)pyrrolidine-2carboxamide (DAT487) (15). Following general procedure A, compound 15 was obtained using acid 11 (synthesized according to the literature ${ }^{20}$ ) in DMF and purified by HPLC using a linear gradient of $5-95 \% \mathrm{MeCN}$ in $0.1 \%$ ammonia in water over $12 \mathrm{~min}$ to afford 15 as a mixture of two diastereomers. Yield: $8.3 \mathrm{mg}(23 \%) ;{ }^{1} \mathrm{H}$ NMR $(400 \mathrm{MHz}, \mathrm{MeOD}): \delta 8.86(\mathrm{~d}, J=1.3 \mathrm{~Hz}, 1 \mathrm{H}), 7.72-7.67(\mathrm{~m}, 1 \mathrm{H})$, $7.56(\mathrm{~d}, J=8.5 \mathrm{~Hz}, 2 \mathrm{H}), 7.46-7.34(\mathrm{~m}, 7 \mathrm{H}), 6.93-6.91(\mathrm{~m}, 1 \mathrm{H})$, $4.79-4.32(\mathrm{~m}, 5 \mathrm{H}), 4.29-4.25(\mathrm{~m}, 1 \mathrm{H}), 4.11-4.02(\mathrm{~m}, 2 \mathrm{H}), 3.90-$ $3.85(\mathrm{~m}, 1 \mathrm{H}), 3.82-3.77(\mathrm{~m}, 4 \mathrm{H}), 3.74-3.40(\mathrm{~m}, 13 \mathrm{H}), 3.30-3.14$ $(\mathrm{m}, 1 \mathrm{H}), 2.59-2.58(\mathrm{~m}, 3 \mathrm{H}), 2.47-2.46(\mathrm{~m}, 3 \mathrm{H}), 2.27-2.17(\mathrm{~m}$, $2 \mathrm{H}), 2.11-2.03(\mathrm{~m}, 1 \mathrm{H}), 1.75-1.63(\mathrm{~m}, 1 \mathrm{H}), 1.07-1.01 \mathrm{ppm}(\mathrm{m}$, $12 \mathrm{H}) ;{ }^{13} \mathrm{C}$ NMR (101 MHz, MeOD): $\delta 175.9,174.42,174.39,172.1$, $171.6,168.8,168.7,159.9,157.3,152.8,152.6,149.0,140.3,140.2$, 138.6, 138.14, 138.11, 133.4, 132.1, 131.5, 131.3, 130.3, 129.6, 129.0, $128.9,127.5,126.8,119.2,116.8,72.3,72.2,71.75,71.67,71.5,71.4$, 71.0, 70.5, 70.4, 60.8, 58.5, 58.4, 58.1, 56.4, 49.84, 49.76, 43.8, 43.7, $40.4,39.0,37.2,37.1,26.99,26.96,24.53,24.46,15.9,11.7,11.6$; 
LCMS $m / z$ : calcd for $\mathrm{C}_{52} \mathrm{H}_{66} \mathrm{ClN}_{9} \mathrm{O}_{9} \mathrm{~S}[\mathrm{M}+2 \mathrm{H}]^{2+}, 513.7$; found, 514.1.

4.1.10. $(2 S, 4 R)-1-((2 S, 17 R *)-2$-(tert-Butyl)-17-((S*)-6-(4-chlorophenyl)-9-methoxy-1-methyl-4H-benzo[f][1,2,4]triazolo[4,3-a][1,4]diazepin-4-yl)-4,16-dioxo-6,9,12-trioxa-3,15-diazaoctadecanoyl)-4-hydroxy-N-(4-(4-methylthiazol-5-yl)benzyl)pyrrolidine-2carboxamide (DAT488) (16). Following general procedure A, compound $\mathbf{1 6}$ was obtained using acid $\mathbf{1 2}$ (synthesized according to the literature ${ }^{20}$ ) in DMF and purified by HPLC using a linear gradient of $5-95 \% \mathrm{MeCN}$ in $0.1 \%$ ammonia in water over $12 \mathrm{~min}$ to afford $\mathbf{1 6}$ as a mixture of two diastereomers. Yield: $13.8 \mathrm{mg}(28 \%) ;{ }^{1} \mathrm{H}$ NMR (400 MHz, MeOD): $\delta 8.87-8.86(\mathrm{~m}, 1 \mathrm{H}), 7.49-7.34(\mathrm{~m}, 9 \mathrm{H})$, 7.31-7.29 (m, 1H), 7.16-7.11 (m, 1H), 4.71-4.69 (m, 1H), 4.62$4.56(\mathrm{~m}, 1 \mathrm{H}), 4.55-4.46(\mathrm{~m}, 2 \mathrm{H}), 4.38-4.32(\mathrm{~m}, 1 \mathrm{H}), 4.25-4.21$ (m, $1 \mathrm{H}), 4.09-4.00(\mathrm{~m}, 2 \mathrm{H}), 3.97-3.96(\mathrm{~m}, 3 \mathrm{H}), 3.90-3.72(\mathrm{~m}$, $3 \mathrm{H}), 3.71-3.59(\mathrm{~m}, 11 \mathrm{H}), 3.53-3.42(\mathrm{~m}, 2 \mathrm{H}), 2.66-2.64(\mathrm{~m}, 3 \mathrm{H})$, $2.47-2.45(\mathrm{~m}, 3 \mathrm{H}), 2.25-2.18(\mathrm{~m}, 1 \mathrm{H}), 2.11-2.04(\mathrm{~m}, 1 \mathrm{H}), 1.36-$ $1.32(\mathrm{~m}, 3 \mathrm{H}), 1.05-1.02 \mathrm{ppm}(\mathrm{m}, 9 \mathrm{H}) ;{ }^{13} \mathrm{C}$ NMR (101 MHz, MeOD): $\delta 177.4,174.39,174.36,172.1,171.7,171.6,168.1,168.0$, $163.6,156.8,152.9,152.8,149.0,140.3,140.2$, 138.9, 137.9, 135.8, $134.34,134.32,133.4,132.4,131.5,130.4,129.4,128.9,122.5,115.2$, 110.6, 72.2, 71.7, 71.6, 71.4, 71.1, 71.0, 70.7, 60.8, 60.7, 58.1, 56.7, 43.9, 43.7, 40.5, 38.9, 37.1, 27.0, 20.0, 16.1, 16.0, 15.9, 11.9; LCMS $m / z$ : calcd for $\mathrm{C}_{51} \mathrm{H}_{64} \mathrm{ClN}_{9} \mathrm{O}_{9} \mathrm{~S}[\mathrm{M}+2 \mathrm{H}]^{2+}, 506.7$; found, 507.1.

4.1.11. (2S,4R)-1-((2S,17R*)-2-(tert-Butyl)-17-((S*)-6-(4-chlorophenyl)-9-methoxy-1-methyl-4H-benzo[f][1,2,4]triazolo[4,3-a][1,4]diazepin-4-yl)-4,16-dioxo-6,9,12-trioxa-3,15-diazanonadecanoyl)-4-hydroxy-N-(4-(4-methylthiazol-5-yl)benzyl)pyrrolidine-2carboxamide (DAT489) (17). Following general procedure A, compound 17 was obtained using acid 13 (synthesized according to the literature $\left.{ }^{20}\right)$ in DMF and purified by HPLC using a linear gradient of $5-95 \% \mathrm{MeCN}$ in $0.1 \%$ ammonia in water over $12 \mathrm{~min}$ to afford $\mathbf{1 7}$ as a mixture of two diastereomers. Yield: $4.8 \mathrm{mg}(20 \%) ;{ }^{1} \mathrm{H}$ NMR $(400 \mathrm{MHz}, \mathrm{MeOD}): \delta 8.87-8.86(\mathrm{~m}, 1 \mathrm{H}), 7.54-7.50(\mathrm{~m}, 2 \mathrm{H})$, $7.46-7.37(\mathrm{~m}, 7 \mathrm{H}), 7.26(\mathrm{~d}, J=2.5 \mathrm{~Hz}, 1 \mathrm{H}), 7.15-7.12(\mathrm{~m}, 1 \mathrm{H})$, $4.74-4.70(\mathrm{~m}, 1 \mathrm{H}), 4.69-4.51(\mathrm{~m}, 2 \mathrm{H}), 4.50-4.46(\mathrm{~m}, 1 \mathrm{H}), 4.42-$ $4.32(\mathrm{~m}, 1 \mathrm{H}), 4.29-4.25(\mathrm{~m}, 1 \mathrm{H}), 4.11-4.02(\mathrm{~m}, 2 \mathrm{H}), 3.96(\mathrm{~s}, 3 \mathrm{H})$, 3.89-3.78 (m, 2H), 3.74-3.39 (m, 13H), 3.29-3.14 (m, 1H), 2.63$2.62(\mathrm{~m}, 3 \mathrm{H}), 2.47-2.46(\mathrm{~m}, 3 \mathrm{H}), 2.28-2.18(\mathrm{~m}, 2 \mathrm{H}), 2.11-2.02$ $(\mathrm{m}, 1 \mathrm{H}), 1.75-1.62(\mathrm{~m}, 1 \mathrm{H}), 1.06-1.01 \mathrm{ppm}(\mathrm{m}, 12 \mathrm{H}) ;{ }^{13} \mathrm{C}$ NMR $(101 \mathrm{MHz}, \mathrm{MeOD}): \delta 176.0,174.42,174.39,172.1,171.6,169.3$, 169.2 , 163.71, 163.69, 157.27, 157.26, 152.8, 152.6, 149.0, 140.3, $140.2,139.1,138.0,138.0,136.0,134.30,134.28,133.4,132.3,131.5$, $130.3,129.5,129.02,128.95,122.6,115.1,110.6,72.4,72.2,71.75$, $71.68,71.50,71.48,71.4,71.09,71.06,70.5,70.4,60.80,60.78,58.4$, 58.3, 58.14, 58.10, 56.7, 49.8, 49.7, 43.8, 43.7, 40.4, 39.0, 37.2, 37.1, 27.00, 26.96, 24.5, 24.4, 15.9, 11.9, 11.7, 11.6; LCMS $m / z$ : calcd for $\mathrm{C}_{52} \mathrm{H}_{66} \mathrm{ClN}_{9} \mathrm{O}_{9} \mathrm{~S}[\mathrm{M}+2 \mathrm{H}]^{2+}, 513.7$; found, 514.2.

4.1.12. (2S,4R)-1-((2S,17R*)-2-(tert-Butyl)-17-((S*)-4-(4-chlorophenyl)-2,3,9-trimethyl-6H-thieno[3,2- $f][1,2,4]$ triazolo $[4,3-a][1,4]-$ diazepin-6-yl)-4,16-dioxo-6,9,12-trioxa-3,15-diazaoctadecanoyl)4-hydroxy-N-(4-(4-methylthiazol-5-yl)benzyl)pyrrolidine-2-carboxamide (ME-MZ1) (18). Following general procedure B, compound 18 was obtained using azide 9 (synthesized according to the literature ${ }^{14}$ ) and alkylated JQ1 acid 32 to afford $\mathbf{1 8}$ as a mixture of two diastereomers. Yield: $1.6 \mathrm{mg}(19 \%) ;{ }^{1} \mathrm{H}$ NMR $\left(400 \mathrm{MHz}, \mathrm{CDCl}_{3}\right): \delta$ $8.67(\mathrm{~s}, 1 \mathrm{H}), 8.07(\mathrm{t}, J=5.4 \mathrm{~Hz}, 1 \mathrm{H}), 7.89(\mathrm{t}, J=5.1 \mathrm{~Hz}, 1 \mathrm{H}), 7.68(\mathrm{t}$, $J=6.0 \mathrm{~Hz}, 1 \mathrm{H}), 7.46-7.24(\mathrm{~m}, 9 \mathrm{H}), 4.85-4.79(\mathrm{~m}, 1 \mathrm{H}), 4.77-4.63$ (m, $1 \mathrm{H}), 4.63-4.47(\mathrm{~m}, 2 \mathrm{H}), 4.42-4.36(\mathrm{~m}, 1 \mathrm{H}), 4.31-4.23(\mathrm{~m}$, $2 \mathrm{H}), 4.18-4.01(\mathrm{~m}, 3 \mathrm{H}), 3.96-3.85(\mathrm{~m}, 1 \mathrm{H}), 3.81-3.36(\mathrm{~m}, 16 \mathrm{H})$, $2.65-2.60(\mathrm{~m}, 3 \mathrm{H}), 2.51(\mathrm{~s}, 3 \mathrm{H}), 2.50-2.37(\mathrm{~m}, 4 \mathrm{H}), 2.26-2.11(\mathrm{~m}$, $1 \mathrm{H}), 1.73-1.64(\mathrm{~m}, 3 \mathrm{H}), 1.42-1.35(\mathrm{~m}, 3 \mathrm{H}), 1.01-0.94 \mathrm{ppm}(\mathrm{m}$, $9 \mathrm{H}) ;{ }^{13} \mathrm{C}$ NMR $\left(101 \mathrm{MHz}, \mathrm{CDCl}_{3}\right): \delta 175.2,171.51,171.49,171.2$, $170.7,170.5,163.3,163.2,158.2,155.14,155.09,150.4,149.8,148.6$, $138.6,138.5,136.9,136.8,136.69,136.65,131.9,131.25,131.15$, $130.8,130.2,129.6,129.5,128.9,128.8,128.2,128.0,71.6,71.4,70.9$, 70.6, 70.5, 70.4, 70.3, 70.25, 70.20, 70.1, 60.5, 60.1, 59.1, 58.9, 57.5, $57.3,56.8,56.7,43.3,43.2,42.7,42.6,39.9,36.4,36.3,35.9,35.8$, 26.6, 26.5, 16.4, 16.2, 16.1, 14.6, 13.3, 11.91, 11.87; HRMS $m / z$ : calcd for $\mathrm{C}_{50} \mathrm{H}_{63} \mathrm{ClN}_{9} \mathrm{O}_{8} \mathrm{~S}_{2}[\mathrm{M}+\mathrm{H}]^{+}$, 1016.3924; found, 1016.3905 .
4.1.13. (2S,4R)-1-((2S,17R*)-2-(tert-Butyl)-17-((S*)-4-(4-chlorophenyl)-2,3,9-trimethyl-6H-thieno[3,2-f][1,2,4]triazolo[4,3-a][1,4]diazepin-6-yl)-4,16-dioxo-6,9,12-trioxa-3,15-diazanonadecanoyl)4-hydroxy-N-(4-(4-methylthiazol-5-yl)benzyl)pyrrolidine-2-carboxamide (ET-MZ1) (19). Following general procedure B, compound 19 was obtained using azide 9 (synthesized according to the literature ${ }^{14}$ ) and alkylated JQ1 acid 33 to afford 19 as a mixture of two diastereomers. Yield: $5.3 \mathrm{mg}(47 \%) ;{ }^{1} \mathrm{H} \mathrm{NMR}\left(500 \mathrm{MHz}, \mathrm{CDCl}_{3}\right): \delta$ 8.68-8.66 (m, 1H), 8.10-8.05 (m, 1H), 7.83-7.79 (m, 1H), 7.69$7.65(\mathrm{~m}, 1 \mathrm{H}), 7.40-7.26(\mathrm{~m}, 8 \mathrm{H}), 7.21-7.16(\mathrm{~m}, 2 \mathrm{H}), 4.87-4.76$ (m, $2 \mathrm{H}), 4.68-4.49(\mathrm{~m}, 2 \mathrm{H}), 4.49-4.36(\mathrm{~m}, 1 \mathrm{H}), 4.28-4.24(\mathrm{~m}$, $1 \mathrm{H}), 4.18-4.00(\mathrm{~m}, 3 \mathrm{H}), 3.81-3.74(\mathrm{~m}, 1 \mathrm{H}), 3.74-3.34(\mathrm{~m}, 13 \mathrm{H})$, $2.65-2.62(\mathrm{~m}, 3 \mathrm{H}), 2.53-2.51(\mathrm{~m}, 3 \mathrm{H}), 2.49-2.44(\mathrm{~m}, 1 \mathrm{H}), 2.41-$ $2.38(\mathrm{~m}, 3 \mathrm{H}), 2.36-2.30(\mathrm{~m}, 1 \mathrm{H}), 2.25-2.11(\mathrm{~m}, 1 \mathrm{H}), 1.97-1.89$ (m, $1 \mathrm{H}), 1.71-1.59(\mathrm{~m}, 4 \mathrm{H}), 1.03-0.93 \mathrm{ppm}(\mathrm{m}, 12 \mathrm{H}) ;{ }^{13} \mathrm{C}$ NMR $\left(126 \mathrm{MHz}, \mathrm{CDCl}_{3}\right): \delta 174.2,173.9,171.7,171.6,171.2,170.4,170.3$, $163.8,163.2,155.3,155.1,150.3,149.9,149.8,148.6,138.7,138.6$, $136.95,136.91,136.8,136.7,132.1,131.94,131.90,131.3,131.1$, $131.0,130.9,130.8,130.7,130.2,130.1,129.9,129.6,129.5,129.0$, 128.8, 128.3, 127.6, 71.3, 71.2, 71.1, 70.9, 70.8, 70.7, 70.50, 70.47, $70.3,70.18,70.15,59.8,59.4,59.2,58.9,57.63,57.59,56.8,50.3,50.1$, 43.3, 43.0, 39.9, 39.8, 36.9, 36.4, 35.90, 35.85, 26.6, 23.7, 23.2, 16.21, $16.19,14.6,14.5,13.2,12.0$; HRMS $m / z$ : calcd for $\mathrm{C}_{51} \mathrm{H}_{65} \mathrm{ClN}_{9} \mathrm{O}_{8} \mathrm{~S}_{2}$ $[\mathrm{M}+\mathrm{H}]^{+}, 1030.4081$; found, 1030.3943 .

4.1.14. (2S,4R)-1-((2S,15R*)-2-(tert-Butyl)-15-((S*)-4-(4-chlorophenyl)-2,3,9-trimethyl-6H-thieno[3,2-f][1,2,4]triazolo[4,3-a][1,4]diazepin-6-yl)-4,14-dioxo-6,10-dioxa-3,13-diazahexadecanoyl)-4-

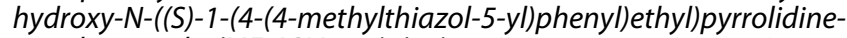
2-carboxamide (ME-ARV-771) (20). Following general procedure $\mathrm{B}$, compound 20 was obtained using azide $\mathbf{4 2}$ (synthesized according to the literature ${ }^{30}$ ) and alkylated JQ1 acid 32 to afford 20 as a mixture of two diastereomers. Yield: $5.2 \mathrm{mg}(31 \%) ;{ }^{1} \mathrm{H}$ NMR $(500 \mathrm{MHz}$, $\left.\mathrm{CDCl}_{3}\right): \delta 8.71-8.69(\mathrm{~m}, 1 \mathrm{H}), 7.66-7.61(\mathrm{~m}, 1 \mathrm{H}), 7.57-7.21(\mathrm{~m}$, $9 \mathrm{H}), 5.14-4.98(\mathrm{~m}, 1 \mathrm{H}), 4.86-4.80(\mathrm{~m}, 1 \mathrm{H}), 4.65-4.47(\mathrm{~m}, 2 \mathrm{H})$, 4.34-4.24 (m, 1H), 4.21-3.77 (m, 4H), 3.75-3.33 (m, 11H), 2.69$2.63(\mathrm{~m}, 3 \mathrm{H}), 2.53-2.50(\mathrm{~m}, 3 \mathrm{H}), 2.41(\mathrm{~s}, 3 \mathrm{H}), 2.38-2.28(\mathrm{~m}, 1 \mathrm{H})$, $2.23-2.10(\mathrm{~m}, 1 \mathrm{H}), 1.92-1.71(\mathrm{~m}, 2 \mathrm{H}), 1.67(\mathrm{~d}, J=3.1 \mathrm{~Hz}, 3 \mathrm{H})$, $1.48(\mathrm{~d}, J=21.4 \mathrm{~Hz}, 3 \mathrm{H}), 1.43-1.35(\mathrm{~m}, 3 \mathrm{H}), 1.10-1.05 \mathrm{ppm}(\mathrm{m}$, $9 \mathrm{H}) ;{ }^{13} \mathrm{C}$ NMR $\left(126 \mathrm{MHz}, \mathrm{CDCl}_{3}\right): \delta 175.3,175.0,171.5,171.4$, $170.8,170.6,170.42,170.38,164.1,163.9,155.0,154.9,150.5,150.22$, $150.16,148.2,143.9,143.7,137.3,136.4,136.1,132.0,131.8,131.33$, $131.26,130.6,130.5,130.3,129.6,129.55,129.48,128.92,128.88$, $126.6,70.4,70.32,70.29,70.2,69.6,69.4,69.2,67.84,67.77,59.9$, $59.8,58.9,58.8,57.5,57.3,57.1,57.0,49.1,48.9,42.6,42.3,39.7$, $39.5,36.6,36.5,35.5,35.3,29.53,29.46,26.7,22.4,22.1,16.5,16.3$, $16.1,14.6,13.3,11.8,11.7$; HRMS $m / z$ : calcd for $\mathrm{C}_{50} \mathrm{H}_{63} \mathrm{ClN}_{9} \mathrm{O}_{7} \mathrm{~S}_{2}$ $[\mathrm{M}+\mathrm{H}]^{+}, 1000.3975$; found, 1000.3975.

4.1.15. (2S,4R)-1-((2S,15R*)-2-(tert-Butyl)-15-((S*)-4-(4-chlorophenyl)-2,3,9-trimethyl-6H-thieno[3,2-f][1,2,4]triazolo[4,3-a][1,4]diazepin-6-yl)-4, 14-dioxo-6,10-dioxa-3,13-diazaheptadecanoyl)-4-

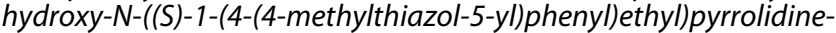
2-carboxamide (ET-ARV-771) (21). Following general procedure B, compound 21 was obtained using azide $\mathbf{4 2}$ (synthesized according to the literature ${ }^{30}$ ) and alkylated JQ1 acid 33 to afford 21 as a mixture of two diastereomers. Yield: $3.4 \mathrm{mg}(27 \%) ;{ }^{1} \mathrm{H}$ NMR (400 $\mathrm{MHz}$, $\left.\mathrm{CDCl}_{3}\right): \delta 8.68(\mathrm{~s}, 1 \mathrm{H}), 7.94-7.90(\mathrm{~m}, 1 \mathrm{H}), 7.71-7.65(\mathrm{~m}, 1 \mathrm{H})$, 7.44-7.31 (m, 7H), 7.25-7.22 (m, 1H), 7.17-7.13 (m, 1H), 5.14$4.87(\mathrm{~m}, 1 \mathrm{H}), 4.75-4.58(\mathrm{~m}, 1 \mathrm{H}), 4.53-4.44(\mathrm{~m}, 1 \mathrm{H}), 4.09-3.98$ $(\mathrm{m}, 1 \mathrm{H}), 3.94-3.87(\mathrm{~m}, 2 \mathrm{H}), 3.80-3.31(\mathrm{~m}, 11 \mathrm{H}), 2.67-2.61(\mathrm{~m}$, $2 \mathrm{H}), 2.54-2.49(\mathrm{~m}, 3 \mathrm{H}), 2.41(\mathrm{~s}, 2 \mathrm{H}), 2.37-2.14(\mathrm{~m}, 2 \mathrm{H}), 1.98-$ $1.47(\mathrm{~m}, 11 \mathrm{H}), 1.11-0.94 \mathrm{ppm}(\mathrm{m}, 12 \mathrm{H}) ;{ }^{13} \mathrm{C}$ NMR $(101 \mathrm{MHz}$, $\left.\mathrm{CDCl}_{3}\right): \delta 174.04,174.00,172.3,171.5,170.59,170.55,170.32$, $170.25,163.6,163.2,162.4,155.3,155.1,150.4,144.0,143.4,137.1$, $136.9,136.6,131.3,131.2,131.1,130.64,130.59,130.5,130.10$, $130.07,130.0,129.6,129.4,128.84,128.80,128.7,126.6,126.5,70.4$, $70.30,70.26,70.2,69.6,69.4,69.1,68.1,67.7,59.6,59.0,58.8,58.6$, $57.4,57.1,57.0,50.3,50.2$, 49.1, 48.8, 39.8, 39.4, 36.6, 35.7, 35.6, $29.8,29.6,29.5,26.7,23.9,23.4,22.5,21.9,16.2,14.61,14.56,13.3$, 12.00, 11.97, 11.91, 11.87; HRMS $m / z$ : calcd for $\mathrm{C}_{51} \mathrm{H}_{65} \mathrm{ClN}_{9} \mathrm{O}_{7} \mathrm{~S}_{2}$ $[\mathrm{M}+\mathrm{H}]^{+}, 1014.4131$; found, 1014.4126. 
4.1.16. (S)-13-((2S,4R)-4-Hydroxy-2-((4-(4-methylthiazol-5-yl)benzyl)carbamoyl)pyrrolidine-1-carbonyl)-14,14-dimethyl-11-oxo3,6,9-trioxa-12-azapentadecyl ( $\left.R^{*}\right)$-2-((S*)-4-(4-chlorophenyl)2,3,9-trimethyl-6H-thieno[3,2-f][1,2,4]triazolo[4,3-a][1,4]diazepin6-yl)propanoate (ME-OMZ1) (22). Following general procedure C, compound 22 was obtained using alkylated JQ1 acid 32 and alcohol 41 (synthesized according to the literature ${ }^{30}$ ) to afford 22 as a mixture of two diastereomers. Yield: $1.1 \mathrm{mg}(17 \%) ;{ }^{1} \mathrm{H}$ NMR (400 $\left.\mathrm{MHz}, \mathrm{CDCl}_{3}\right): \delta 8.69-8.67(\mathrm{~m}, 1 \mathrm{H}), 7.67-7.65(\mathrm{~m}, 1 \mathrm{H}), 7.44-7.28$ $(\mathrm{m}, 10 \mathrm{H}), 4.78-4.73(\mathrm{~m}, 1 \mathrm{H}), 4.69-4.50(\mathrm{~m}, 3 \mathrm{H}), 4.41-4.24(\mathrm{~m}$, $3 \mathrm{H}), 4.13-3.81(\mathrm{~m}, 5 \mathrm{H}), 3.77-3.49(\mathrm{~m}, 12 \mathrm{H}), 2.63(\mathrm{~d}, J=15.9 \mathrm{~Hz}$, $3 \mathrm{H}), 2.59-2.50(\mathrm{~m}, 4 \mathrm{H}), 2.42(\mathrm{~s}, 3 \mathrm{H}), 1.73-1.66(\mathrm{~m}, 3 \mathrm{H}), 1.58-$ $1.48(\mathrm{~m}, 3 \mathrm{H}), 0.99-0.94 \mathrm{ppm}(\mathrm{m}, 9 \mathrm{H}) ;{ }^{13} \mathrm{C}$ NMR $(101 \mathrm{MHz}$, $\left.\mathrm{CDCl}_{3}\right): \delta 175.4,171.6,170.9,170.6,170.5,163.2,154.5,150.4$, $149.8,148.7,142.1,140.3,138.4,136.9,136.6,132.4,131.7,131.1$, $131.0,131.0,130.0,129.6,128.9,128.8,128.3,71.30,71.28,71.0$, $70.93,70.89,70.7,70.6,70.5,70.44,70.36,69.3,64.1,64.0,61.8,61.7$, $60.2,60.1,58.7,58.6,57.3,56.8,56.7,43.4,42.7,42.6,36.1,36.0$, 35.2, 26.6, 16.2, 16.1, 15.4, 15.3, 14.60, 14.56, 13.3, 11.9; HRMS $m / z$ : calcd for $\mathrm{C}_{50} \mathrm{H}_{62} \mathrm{ClN}_{8} \mathrm{O}_{9} \mathrm{~S}_{2}[\mathrm{M}+\mathrm{H}]^{+}, 1017.3764$; found, 1017.3780.

4.1.17. (S)-13-((2S,4R)-4-Hydroxy-2-((4-(4-methylthiazol-5-yl)benzyl)carbamoyl)pyrrolidine-1-carbonyl)-14,14-dimethyl-11-oxo3,6,9-trioxa-12-azapentadecyl ( $\left.R^{*}\right)$-2-((S*)-4-(4-chlorophenyl)2,3,9-trimethyl-6H-thieno[3,2-f][1,2,4]triazolo[4,3-a][1,4]diazepin6-yl)butanoate (ET-OMZ1) (23). Following general procedure C, compound 23 was obtained using alkylated JQ1 acid 33 and alcohol 41 (synthesized according to the literature ${ }^{30}$ ) to afford 23 as a mixture of two diastereomers. Yield: $0.7 \mathrm{mg}(10 \%) ;{ }^{1} \mathrm{H}$ NMR (500 $\left.\mathrm{MHz}, \mathrm{CDCl}_{3}\right): \delta 8.67(\mathrm{~s}, 1 \mathrm{H}), 7.41-7.23(\mathrm{~m}, 10 \mathrm{H}), 4.77(\mathrm{t}, J=7.9$ $\mathrm{Hz}, 1 \mathrm{H}), 4.60-4.31(\mathrm{~m}, 6 \mathrm{H}), 4.24(\mathrm{~d}, J=10.9 \mathrm{~Hz}, 1 \mathrm{H}), 4.15-4.11$ $(\mathrm{m}, 1 \mathrm{H}), 4.05-3.89(\mathrm{~m}, 3 \mathrm{H}), 3.80-3.74(\mathrm{~m}, 2 \mathrm{H}), 3.72-3.52(\mathrm{~m}$, $10 \mathrm{H}), 2.65(\mathrm{~s}, 3 \mathrm{H}), 2.60-2.51(\mathrm{~m}, 4 \mathrm{H}), 2.41(\mathrm{~s}, 3 \mathrm{H}), 2.17-2.10(\mathrm{~m}$, $2 \mathrm{H}), 1.71-1.64(\mathrm{~m}, 4 \mathrm{H}), 1.05-0.93 \mathrm{ppm}(\mathrm{m}, 12 \mathrm{H}) ;{ }^{13} \mathrm{C}$ NMR $(126$ $\left.\mathrm{MHz}, \mathrm{CDCl}_{3}\right): \delta 174.8,174.1,171.5,171.1,170.5,163.2,163.0$, $154.6,150.4,149.9,148.7,141.2,136.9,136.7,132.2,131.8,131.0$, $130.7,130.0,129.7,128.8,128.4,128.3,71.32,71.30,70.98,70.96$, $70.91,70.85,70.8,70.7,70.6,70.54,70.51,70.3,69.3,63.9,63.8,59.4$, $58.5,57.3,56.8,49.8,49.7,43.44,43.41,36.0,35.1,26.6,23.4,16.2$, 14.6, 13.3, 11.9, 11.7, 16.1, 15.4, 15.3, 14.60, 14.56, 13.3, 11.9; HRMS $m / z$ : calcd for $\mathrm{C}_{51} \mathrm{H}_{64} \mathrm{ClN}_{8} \mathrm{O}_{9} \mathrm{~S}_{2}[\mathrm{M}+\mathrm{H}]^{+}, 1031.3921$; found, 1031.4061.

4.1.18. 2-(3-(2-)((S)-1-((2S,4R)-4-Hydroxy-2-(((S)-1-(4-(4-methylthiazol-5-yl)phenyl)ethyl)carbamoyl)pyrrolidin-1-yl)-3,3-dimethyl1-oxobutan-2-yl)amino)-2-oxoethoxy)propoxy)ethyl $\left(R^{*}\right)-2-\left(\left(S^{*}\right)-4\right.$ (4-chlorophenyl)-2,3,9-trimethyl-6H-thieno[3,2-f][1,2,4]triazolo[4,3-a][1,4]diazepin-6-yl)propanoate (ME-OARV-771) (24). Following general procedure $C$, compound 24 was obtained using alkylated JQ1 acid 32 and alcohol 44 (synthesized according to the literature ${ }^{30}$ ) to afford 24 as a mixture of two diastereomers. Yield: $1.8 \mathrm{mg}(25 \%)$; ${ }^{1} \mathrm{H}$ NMR $\left(500 \mathrm{MHz}, \mathrm{CDCl}_{3}\right): \delta 8.68-8.66(\mathrm{~m}, 1 \mathrm{H}), 7.51-7.44(\mathrm{~m}$, $1 \mathrm{H}), 7.42-7.28(\mathrm{~m}, 8 \mathrm{H}), 7.23-7.16(\mathrm{~m}, 1 \mathrm{H}), 5.52(\mathrm{br} \mathrm{s}, 1 \mathrm{H}), 5.14-$ $5.06(\mathrm{~m}, 1 \mathrm{H}), 4.81-4.71(\mathrm{~m}, 1 \mathrm{H}), 4.70-4.51(\mathrm{~m}, 2 \mathrm{H}), 4.43-4.31$ $(\mathrm{m}, 2 \mathrm{H}), 4.27(\mathrm{~d}, J=10.5 \mathrm{~Hz}, 1 \mathrm{H}), 4.13-4.08(\mathrm{~m}, 1 \mathrm{H}), 4.07-3.81$ (m, $4 \mathrm{H}), 3.75-3.54(\mathrm{~m}, 8 \mathrm{H}), 3.19($ br s, $1 \mathrm{H}), 2.66-2.62(\mathrm{~m}, 3 \mathrm{H})$, $2.59-2.52(\mathrm{~m}, 4 \mathrm{H}), 2.42(\mathrm{~s}, 3 \mathrm{H}), 2.17-2.08(\mathrm{~m}, 1 \mathrm{H}), 1.96-1.85(\mathrm{~m}$, $2 \mathrm{H}), 1.69(\mathrm{~d}, J=4.8 \mathrm{~Hz}, 3 \mathrm{H}), 1.56-1.47(\mathrm{~m}, 6 \mathrm{H}), 1.08-1.05 \mathrm{ppm}$ $(\mathrm{m}, 9 \mathrm{H}) ;{ }^{13} \mathrm{C}$ NMR $\left(126 \mathrm{MHz}, \mathrm{CDCl}_{3}\right): \delta 175.4,174.3,171.8,171.5$, $170.3,169.8,169.7,169.5,163.1,154.5,150.3,149.8,148.7,136.9$, $136.7,132.2,131.8,131.0,130.7,130.0,129.7,128.9,128.8,126.65$, $126.60,73.2,72.2,70.5,70.4,70.3,69.3,69.0,68.9,68.0,67.9,63.9$, $61.9,60.1,59.6,58.8,58.5,57.2,56.8,56.6,53.6,49.1,49.0,42.6$, $35.6,35.3,33.5,30.0,26.7,26.6,22.4,22.3,16.2,15.3,14.60,14.55$, 14.3, 13.2, 11.9; HRMS $m / z$ : calcd for $\mathrm{C}_{50} \mathrm{H}_{62} \mathrm{ClN}_{8} \mathrm{O}_{8} \mathrm{~S}_{2}[\mathrm{M}+\mathrm{H}]^{+}$, 1001.3815; found, 1001.3967 .

4.1.19. 2-(3-(2-(((S)-1-((2S,4R)-4-Hydroxy-2-(((S)-1-(4-(4-methylthiazol-5-yl)phenyl)ethyl)carbamoyl)pyrrolidin-1-yl)-3,3-dimethyl1-oxobutan-2-yl)amino)-2-oxoethoxy)propoxy)ethyl ( $\left.R^{*}\right)-2-\left(\left(S^{*}\right)-4\right.$ (4-chlorophenyl)-2,3,9-trimethyl-6H-thieno[3,2-f][1,2,4]triazolo[4,3-a][1,4]diazepin-6-yl)butanoate (ET-OARV-771) (25). Following general procedure $\mathrm{C}$, compound $\mathbf{2 4}$ was obtained using alkylated JQ1 acid 32 and alcohol 44 (synthesized according to the literature ${ }^{30}$ ) to afford 24 as a mixture of two diastereomers. Yield: $1.7 \mathrm{mg}(24 \%) ;{ }^{1} \mathrm{H}$ NMR $\left(500 \mathrm{MHz}, \mathrm{CDCl}_{3}\right): \delta 8.66(\mathrm{~s}, 1 \mathrm{H}), 7.47-7.28(\mathrm{~m}, 10 \mathrm{H})$, $7.20-7.13(\mathrm{~m}, 1 \mathrm{H}), 5.12-5.04(\mathrm{~m}, 1 \mathrm{H}), 4.81-4.75(\mathrm{~m}, 1 \mathrm{H}), 4.70-$ $4.52(\mathrm{~m}, 2 \mathrm{H}), 4.49-4.31(\mathrm{~m}, 2 \mathrm{H}), 4.28-4.22(\mathrm{~m}, 1 \mathrm{H}), 4.18-4.11$ (m, $1 \mathrm{H}), 4.07-3.94(\mathrm{~m}, 2 \mathrm{H}), 3.91-3.81(\mathrm{~m}, 2 \mathrm{H}), 3.80-3.64(\mathrm{~m}$, $3 \mathrm{H}), 3.63-3.54(\mathrm{~m}, 5 \mathrm{H}), 3.07(\mathrm{~s}, 1 \mathrm{H}), 2.67-2.65(\mathrm{~m}, 3 \mathrm{H}), 2.59-$ $2.52(\mathrm{~m}, 4 \mathrm{H}), 2.41(\mathrm{~s}, 3 \mathrm{H}), 2.19-2.05(\mathrm{~m}, 2 \mathrm{H}), 1.96-1.85(\mathrm{~m}, 2 \mathrm{H})$, $1.72-1.64(\mathrm{~m}, 4 \mathrm{H}), 1.49-1.46(\mathrm{~m}, 3 \mathrm{H}), 1.07-1.01 \mathrm{ppm}(\mathrm{m}, 12 \mathrm{H})$; ${ }^{13} \mathrm{C}$ NMR $\left(126 \mathrm{MHz}, \mathrm{CDCl}_{3}\right): \delta 175.0,174.9,171.9,171.8,170.42$, $170.38,169.8,169.7,163.2,154.6,154.5,150.3,149.89,149.85,148.7$, $143.42,143.36,136.92,136.90,136.71,136.67,131.8,131.0,130.1$, $130.0,129.7,128.8,126.6,72.2,70.32,70.26,70.2,69.3,69.0,68.9$, $68.0,67.9,63.8,62.0,59.4,58.45,58.40,57.2,56.8,56.7,49.8,49.7$, 49.0, 35.6, 35.4, 35.2, 35.1, 30.1, 26.7, 26.6, 23.43, 23.39, 22.4, 16.2, 14.6, 13.3, 12.0, 11.7; HRMS $m / z$ : calcd for $\mathrm{C}_{51} \mathrm{H}_{64} \mathrm{ClN}_{8} \mathrm{O}_{8} \mathrm{~S}_{2}[\mathrm{M}+$ $\mathrm{H}]^{+}, 1015.3972$; found, 1015.4032 .

4.1.20. Methyl 2-(5-(4-chlorophenyl)-6,7-dimethyl-2-oxo-2,3-dihydro-1H-thieno[2,3-e][1,4]diazepin-3-yl)acetate (28). Fmoc-Asp$(\mathrm{OMe})-\mathrm{OH}(26)(1.92 \mathrm{~g}, 5.19 \mathrm{mmol})$ was dissolved in DCM (25 $\mathrm{mL})$. Thionyl chloride $(3.76 \mathrm{~mL}, 51.9 \mathrm{mmol})$ was added, and the reaction was left to reflux for $2 \mathrm{~h}$. The reaction mixture was then concentrated in vacuo to yield the intermediate acid chloride. Acid chloride $(2.01 \mathrm{~g}, 5.19 \mathrm{mmol})$ was dissolved in chloroform $(10 \mathrm{~mL})$. (2-Amino-4,5-dimethylthiophen-3-yl)(4-chlorophenyl)methanone (27) $(1.38 \mathrm{~g}, 5.19 \mathrm{mmol})$ was then added, and the flask was heated to reflux and stirred for $1 \mathrm{~h}$. The mixture was then cooled to r.t. before TEA $(2.89 \mathrm{~mL}, 20.76 \mathrm{mmol})$ was added. The flask was heated to reflux for a further $16 \mathrm{~h}$. The reaction mixture was then concentrated in vacuo and redissolved in 1,2-DCE $(50 \mathrm{~mL})$ and acidified with $\mathrm{AcOH}(3.5 \mathrm{~mL})$. This was left to stir at $80{ }^{\circ} \mathrm{C}$ for $1 \mathrm{~h}$. The mixture was then evaporated to dryness before redissolving in DCM $(50 \mathrm{~mL})$ and washing with $1.0 \mathrm{M} \mathrm{HCl}$ solution $(40 \mathrm{~mL})$. The aqueous phase was extracted with DCM $(3 \times 50 \mathrm{~mL})$, and the combined organic layers were dried with $\mathrm{MgSO}_{4}$, filtered, and concentrated in vacuo. The residue was purified by flash column chromatography ( $24 \mathrm{~g}$ silica column) using a linear gradient from 0 to $80 \%$ EtOAc in heptane to afford 28. Yield: $1.06 \mathrm{~g}(54 \%) ;{ }^{1} \mathrm{H}$ NMR $\left(500 \mathrm{MHz}, \mathrm{CDCl}_{3}\right): \delta 7.43$ $(\mathrm{d}, J=8.6 \mathrm{~Hz}, 2 \mathrm{H}), 7.34(\mathrm{~d}, J=8.7 \mathrm{~Hz}, 2 \mathrm{H}), 4.26(\mathrm{dd}, J=6.6,7.4 \mathrm{~Hz}$, $1 \mathrm{H}), 3.74(\mathrm{~s}, 3 \mathrm{H}), 3.44$ (dd, $J=7.5,16.8 \mathrm{~Hz}, 1 \mathrm{H}), 3.17(\mathrm{dd}, J=6.5$, $16.8 \mathrm{~Hz}, 1 \mathrm{H}), 2.29(\mathrm{~s}, 3 \mathrm{H}), 1.60 \mathrm{ppm}(\mathrm{s}, 3 \mathrm{H})$; LCMS $\mathrm{m} / z$ : calcd for $\mathrm{C}_{18} \mathrm{H}_{18} \mathrm{ClN}_{2} \mathrm{O}_{3} \mathrm{~S}[\mathrm{M}+\mathrm{H}]^{+}$, 377.1; found, 377.0.

4.1.21. Methyl 2-(4-(4-chlorophenyl)-2,3,9-trimethyl-6H-thieno$[3,2-f][1,2,4]$ triazolo[4,3-a][1,4]diazepin-6-yl)acetate [( \pm -JQ1OMe] (29). Compound $28(344 \mathrm{mg}, 0.91 \mathrm{mmol})$ was dissolved in THF $(7 \mathrm{~mL})$ and cooled to $-78{ }^{\circ} \mathrm{C}$ before addition of a solution of $1.0 \mathrm{M} \mathrm{KO} t \mathrm{Bu}$ in THF $(1.37 \mathrm{~mL}, 1.37 \mathrm{mmol})$ and stirred for $30 \mathrm{~min}$. Diethyl chlorophosphate $(198 \mu \mathrm{L}, 1.37 \mathrm{mmol})$ was then added, and the reaction was warmed to $-10{ }^{\circ} \mathrm{C}$ and stirred for $45 \mathrm{~min}$. Acetyl hydrazine ( $135 \mathrm{mg}, 1.82 \mu \mathrm{mol}$ ) was then added, and the reaction was left to stir at r.t. for 1 h. $n-\mathrm{BuOH}(7.8 \mathrm{~mL})$ was then added before heating to $90{ }^{\circ} \mathrm{C}$ for $1 \mathrm{~h}$. The reaction was concentrated in vacuo, and the residue was purified by flash column chromatography (40 g silica column) using a linear gradient from 3 to $50 \%$ EtOAc in heptane to remove the starting material and the column was flushed with $20 \%$ $\mathrm{MeOH}$ in DCM. Some fractions were further purified by HPLC using a linear gradient of $35-55 \% \mathrm{MeCN}$ in $0.1 \%$ formic acid in water over $12 \mathrm{~min}$ to afford 29. Yield: $173 \mathrm{mg}(46 \%) ;{ }^{1} \mathrm{H}$ NMR (400 MHz, $\left.\mathrm{CDCl}_{3}\right): \delta 7.41(\mathrm{~d}, J=8.2 \mathrm{~Hz}, 2 \mathrm{H}), 7.33(\mathrm{~d}, J=8.4 \mathrm{~Hz}, 2 \mathrm{H}), 4.62$ (dd, $J=6.9,6.9 \mathrm{~Hz}, 1 \mathrm{H}), 3.77(\mathrm{~s}, 3 \mathrm{H}), 3.70-3.57(\mathrm{~m}, 2 \mathrm{H}), 2.67(\mathrm{~s}$, $3 \mathrm{H}), 2.41(\mathrm{~s}, 3 \mathrm{H}), 1.69 \mathrm{ppm}(\mathrm{s}, 3 \mathrm{H}) ;$ LCMS $\mathrm{m} / \mathrm{z}$ : calcd for $\mathrm{C}_{20} \mathrm{H}_{20} \mathrm{ClN}_{4} \mathrm{O}_{2} \mathrm{~S}[\mathrm{M}+\mathrm{H}]^{+}$, 415.1; found, 415.0.

4.1.22. ( \pm -Methyl (R)-2-((S)-4-(4-chlorophenyl)-2,3,9-trimethyl$6 \mathrm{H}$-thieno[3,2-f][1,2,4]triazolo[4,3-a][1,4]diazepin-6-yl)propanoate [( \pm )-(3S,2R)-ME-JQ1-OMe] (30a). Following general procedure D, compound 30a was obtained using an alkylating agent, methyl iodide. Yield $8.9 \mathrm{mg}$ (7\%). Following general procedure E, compound 30a can also be obtained from epimerization of $30 \mathrm{~b}$. Isolated yield: $12 \mathrm{mg}$ (31\%); ${ }^{1} \mathrm{H}$ NMR (500 MHz, $\mathrm{CDCl}_{3}$ ): $\delta 7.34$ (d, $\left.J=8.7 \mathrm{~Hz}, 2 \mathrm{H}\right), 7.31$ (d, $J=8.8 \mathrm{~Hz}, 2 \mathrm{H}), 4.25(\mathrm{~d}, J=10.7 \mathrm{~Hz}, 1 \mathrm{H}), 4.07$ (qd, $J=6.9,10.7$ $\mathrm{Hz}, 1 \mathrm{H}), 3.83(\mathrm{~s}, 3 \mathrm{H}), 2.67$ (s, 3H), $2.42(\mathrm{~s}, 3 \mathrm{H}), 1.69(\mathrm{~s}, 3 \mathrm{H}), 1.51$ 
$\operatorname{ppm}(\mathrm{d}, J=6.9 \mathrm{~Hz}, 3 \mathrm{H}) ;{ }^{13} \mathrm{C}$ NMR $\left(126 \mathrm{MHz}, \mathrm{CDCl}_{3}\right): \delta 176.1$, $163.2,154.5,149.8,136.9,136.7,132.3,131.1,130.9,130.7,130.0$, $128.8,60.4,51.9,42.6,15.4,14.6,13.2,12.0$; LCMS $m / z$ : calcd for $\mathrm{C}_{21} \mathrm{H}_{22} \mathrm{ClN}_{4} \mathrm{O}_{2} \mathrm{~S}[\mathrm{M}+\mathrm{H}]^{+}$, 429.1; found, 429.0.

4.1.23. ( \pm )-Methyl (S)-2-((S)-4-(4-chlorophenyl)-2,3,9-trimethyl$6 H$-thieno[3,2-f][1,2,4]triazolo[4,3-a][1,4]diazepin-6-yl)propanoate $[( \pm)-(3 S, 2 S)-M E-J Q 1-O M e](30 b)$. Following general procedure D, compound $30 \mathrm{~b}$ was obtained using an alkylating agent, methyl iodide. Yield $35.4 \mathrm{mg}(29 \%) ;{ }^{1} \mathrm{H}$ NMR $\left(500 \mathrm{MHz}, \mathrm{CDCl}_{3}\right): \delta 7.43$ (d, $J=8.4$ $\mathrm{Hz}, 2 \mathrm{H}), 7.33$ (d, $J=8.5 \mathrm{~Hz}, 2 \mathrm{H}), 4.31(\mathrm{~d}, J=9.8 \mathrm{~Hz}, 1 \mathrm{H}), 3.88(\mathrm{qd}$, $J=7.2,9.7 \mathrm{~Hz}, 1 \mathrm{H}), 3.72(\mathrm{~s}, 3 \mathrm{H}), 2.64(\mathrm{~s}, 3 \mathrm{H}), 2.41(\mathrm{~s}, 3 \mathrm{H}), 1.70(\mathrm{~s}$, $3 \mathrm{H}), 1.62 \mathrm{ppm}(\mathrm{d}, J=7.2 \mathrm{~Hz}, 3 \mathrm{H}) ;{ }^{13} \mathrm{C}$ NMR $\left(126 \mathrm{MHz}, \mathrm{CDCl}_{3}\right): \delta$ $176.1,163.9,155.5,149.6,136.95,136.90,132.7,130.8,130.4,129.9$, $128.8,58.5,52.1,41.2,15.4,14.5,13.2,11.9$; LCMS $m / z$ : calcd for $\mathrm{C}_{21} \mathrm{H}_{22} \mathrm{ClN}_{4} \mathrm{O}_{2} \mathrm{~S}[\mathrm{M}+\mathrm{H}]^{+}$, 429.1; found, 429.0.

4.1.24. ( \pm -Methyl (R)-2-((S)-4-(4-chlorophenyl)-2,3,9-trimethyl$6 \mathrm{H}$-thieno[3,2-f][1,2,4]triazolo[4,3-a][1,4]diazepin-6-yl)butanoate [( \pm$)-(3 S, 2 R)-E T-J Q 1-O M e]$ (31a). Following general procedure D, compound 31a was obtained using an alkylating agent, ethyl iodide. Yield $20 \mathrm{mg}$ (16\%). Following general procedure E, compound 31a can also be obtained from epimerization of $31 \mathrm{~b}$. Isolated yield: $11 \mathrm{mg}$ $(37 \%) ;{ }^{1} \mathrm{H}$ NMR $\left(500 \mathrm{MHz}, \mathrm{CDCl}_{3}\right): \delta 7.35-7.29(\mathrm{~m}, 4 \mathrm{H}), 4.24(\mathrm{~d}$, $J=10.9 \mathrm{~Hz}, 1 \mathrm{H}), 3.99(\mathrm{dt}, J=3.7,10.7 \mathrm{~Hz}, 1 \mathrm{H}), 3.84(\mathrm{~s}, 3 \mathrm{H}), 2.66$ $(\mathrm{s}, 3 \mathrm{H}), 2.41(\mathrm{~s}, 3 \mathrm{H}), 2.23-2.13(\mathrm{~m}, 1 \mathrm{H}), 1.73-1.63(\mathrm{~m}, 4 \mathrm{H}), 1.02$ ppm $(\mathrm{t}, J=7.4 \mathrm{~Hz}, 3 \mathrm{H}) ;{ }^{13} \mathrm{C}$ NMR $\left(126 \mathrm{MHz} \mathrm{CDCl}_{3}\right): \delta 175.5$, 163.2, 154.6, 149.8, 136.9, 136.7, 132.3, 131.0, 130.9, 130.6, 129.9, $128.8,59.5,51.6,49.8,23.4,14.6,13.2,12.0,11.7$; LCMS $m / z$ : calcd for $\mathrm{C}_{22} \mathrm{H}_{24} \mathrm{ClN}_{4} \mathrm{O}_{2} \mathrm{~S}[\mathrm{M}+\mathrm{H}]^{+}$, 443.1; found, 443.1.

4.1.25. ( \pm )-Methyl (S)-2-((S)-4-(4-chlorophenyl)-2,3,9-trimethyl$6 H$-thieno[3,2-f][1,2,4]triazolo[4,3-a][1,4]diazepin-6-yl)butanoate [( \pm$)-(3 S, 2 S)-E T-J Q 1-O M e]$ (31b). Following general procedure $B$, compound $3 \mathbf{3 b}$ was obtained using an alkylating agent, ethyl iodide. Yield $29.2 \mathrm{mg}(23 \%) ;{ }^{1} \mathrm{H}$ NMR (500 MHz, $\left.\mathrm{CDCl}_{3}\right): \delta 7.42(\mathrm{~d}, J=8.4$ $\mathrm{Hz}, 2 \mathrm{H}), 7.33$ (d, $J=8.5 \mathrm{~Hz}, 2 \mathrm{H}), 4.31(\mathrm{~d}, J=10.9 \mathrm{~Hz}, 1 \mathrm{H}), 3.83(\mathrm{dt}$, $J=3.6,10.1 \mathrm{~Hz}, 1 \mathrm{H}), 3.73(\mathrm{~s}, 3 \mathrm{H}), 2.64(\mathrm{~s}, 3 \mathrm{H}), 2.41(\mathrm{~s}, 3 \mathrm{H}), 2.37-$ $2.26(\mathrm{~m}, 1 \mathrm{H}), 1.93-1.82(\mathrm{~m}, 1 \mathrm{H}), 1.69(\mathrm{~s}, 3 \mathrm{H}), 1.05 \mathrm{ppm}(\mathrm{t}, J=7.5$ $\mathrm{Hz}, 3 \mathrm{H}) ;{ }^{13} \mathrm{C}$ NMR $\left(126 \mathrm{MHz}, \mathrm{CDCl}_{3}\right): \delta 175.5,163.9,155.4,149.6$, $136.95,136.90,132.7,130.8,130.7,130.3,129.9,128.8,57.6,51.9$, $47.6,23.4,14.5,13.2,11.9,11.2$; LCMS $m / z$ : calcd for $\mathrm{C}_{22} \mathrm{H}_{24} \mathrm{ClN}_{4} \mathrm{O}_{2} \mathrm{~S}[\mathrm{M}+\mathrm{H}]^{+}$, 443.1; found, 443.1.

4.1.26. ( \pm )-(R)-2-((S)-4-(4-Chlorophenyl)-2,3,9-trimethyl-6Hthieno[3,2-f][1,2,4]triazolo[4,3-a][1,4]diazepin-6-yl)propanoic Acid [( \pm )-(3S,2R)-ME-JQ1-OH] (32). Compound 30a (8.2 mg, 19 $\mu \mathrm{mol})$ was dissolved in THF $(400 \mu \mathrm{L})$. LiOH $(1 \mathrm{mg}, 38 \mu \mathrm{mol})$ was subsequently dissolved in water $(100 \mu \mathrm{L})$ and added to the flask. The flask was heated to $35^{\circ} \mathrm{C}$ and stirred for $48 \mathrm{~h}$. Water $(25 \mu \mathrm{L})$ and 0.6 $\mathrm{M} \mathrm{LiOH}$ solution $(25 \mu \mathrm{L})$ were added at regular intervals (every 12 h) to assist with the conversion. The conversion of the ester to the acid was monitored by liquid chromatography-mass spectrometry (LC-MS). After $100 \%$ conversion, the solution was neutralized with 2.0 M HCl solution and freeze-dried to afford acid 32. The acid was used as crude for the next step and the yield considered quantitative. Yield: $7.9 \mathrm{mg}$, (quant.); ${ }^{1} \mathrm{H}$ NMR (500 $\mathrm{MHz}, \mathrm{CDCl}_{3}$ ): $\delta 7.34$ (d, $J=$ $8.8 \mathrm{~Hz}, 2 \mathrm{H}), 7.31(\mathrm{~d}, J=8.9 \mathrm{~Hz}, 2 \mathrm{H}), 4.25(\mathrm{~d}, J=10.6 \mathrm{~Hz}, 1 \mathrm{H}), 4.07$ $(\mathrm{m}, 1 \mathrm{H}), 3.83(\mathrm{~s}, 3 \mathrm{H}), 2.67(\mathrm{~s}, 3 \mathrm{H}), 2.42(\mathrm{~s}, 3 \mathrm{H}), 1.69(\mathrm{~s}, 3 \mathrm{H}), 1.51$ ppm $(\mathrm{d}, J=7.0 \mathrm{~Hz}, 3 \mathrm{H}) ;{ }^{13} \mathrm{C}$ NMR $\left(126 \mathrm{MHz}, \mathrm{CDCl}_{3}\right): \delta 175.8$, $164.8,154.6,150.3,137.7,135.7,132.4,131.6,131.4,130.9,130.3$, 129.0, 59.1, 41.5, 15.6, 14.6, 13.4, 11.8; LCMS $\mathrm{m} / z$ : calcd for $\mathrm{C}_{20} \mathrm{H}_{20} \mathrm{ClN}_{4} \mathrm{O}_{2} \mathrm{~S}[\mathrm{M}+\mathrm{H}]^{+}$, 415.1; found, 415.1.

4.1.27. ( \pm )-(R)-2-((S)-4-(4-Chlorophenyl)-2,3,9-trimethyl-6Hthieno[3,2-f][1,2,4]triazolo[4,3-a][1,4]diazepin-6-yl)butanoic Acid $[( \pm)-(3 S, 2 R)-E T-J Q 1-O H]$ (33). Compound 31a $(35.2 \mathrm{mg}, 80 \mu \mathrm{mol})$ was dissolved in THF $(1.2 \mathrm{~mL})$. $\mathrm{LiOH}(4.8 \mathrm{mg}, 200 \mu \mathrm{mol})$ was subsequently dissolved in water $(300 \mu \mathrm{L})$ and added to the flask. The flask was heated to $40{ }^{\circ} \mathrm{C}$ and stirred for 6 days. Water $(50 \mu \mathrm{L})$ and $0.65 \mathrm{M} \mathrm{LiOH}$ solution $(50 \mu \mathrm{L})$ were added at regular intervals (every $12 \mathrm{~h}$ ) to assist with the conversion. The conversion of the ester to the acid was monitored by LC-MS. After $100 \%$ conversion, the solution was neutralized with $2.0 \mathrm{M} \mathrm{HCl}$ solution and freeze-dried to afford acid 33. The acid was used as crude for the next step and the yield considered quantitative. Yield: $34.3 \mathrm{mg}$, (quant.); ${ }^{1} \mathrm{H}$ NMR (500
$\left.\mathrm{MHz}, \mathrm{CDCl}_{3}\right): \delta 7.41(\mathrm{~d}, J=8.5 \mathrm{~Hz}, 2 \mathrm{H}), 7.32(\mathrm{~d}, J=8.7 \mathrm{~Hz}, 2 \mathrm{H})$, $4.24(\mathrm{~d}, J=6.5 \mathrm{~Hz}, 1 \mathrm{H}), 3.75-3.70(\mathrm{~m}, 1 \mathrm{H}), 2.69(\mathrm{~s}, 3 \mathrm{H}), 2.43(\mathrm{~s}$, $3 \mathrm{H}), 2.03-1.95(\mathrm{~m}, 2 \mathrm{H}), 1.71(\mathrm{~s}, 3 \mathrm{H}), 1.10 \mathrm{ppm}(\mathrm{t}, J=7.4 \mathrm{~Hz}, 3 \mathrm{H})$; ${ }^{13} \mathrm{C}$ NMR $\left(126 \mathrm{MHz}, \mathrm{CDCl}_{3}\right): \delta 175.2,164.6,154.9,150.1,137.5$, 136.1, 132.5, 131.5, 131.2, 130.2, 130.1, 129.0, 58.2, 48.6, 23.8, 14.6, 13.3, 11.9; LCMS $m / z$ : calcd for $\mathrm{C}_{21} \mathrm{H}_{22} \mathrm{ClN}_{4} \mathrm{O}_{2} \mathrm{~S}[\mathrm{M}+\mathrm{H}]^{+}$, 429.1; found, 429.1 .

4.1.28. (S)-13-((2S,4R)-4-Hydroxy-2-((4-(4-methylthiazol-5-yl)benzyl)carbamoyl)pyrrolidine-1-carbonyl)-14, 14-dimethyl-11-oxo3,6,9-trioxa-12-azapentadecyl (R)-2-((S)-4-(4-chlorophenyl)-2,3,9trimethyl-6H-thieno[3,2-f][1,2,4]triazolo[4,3-a][1,4]diazepin-6-yl)butanoate (AGB1) (46). Following general procedure F, compound 46 was obtained using alcohol 41 (synthesized according to the literature ${ }^{30}$ ) and purified by reversed-phase flash column chromatography ( $15.5 \mathrm{~g}$ of $\mathrm{C} 18$ gold column) using a linear gradient from 5 to $100 \% \mathrm{MeCN}$ in $0.1 \%$ formic acid in water over $12 \mathrm{~min}$ to afford AGB1 (46). Yield: $29 \mathrm{mg}(30 \%) ;{ }^{1} \mathrm{H} \mathrm{NMR}$ (500 $\left.\mathrm{MHz}, \mathrm{CDCl}_{3}\right): \delta$ $8.67(\mathrm{~s}, 1 \mathrm{H}), 7.42(\mathrm{t}, J=5.9 \mathrm{~Hz}, 1 \mathrm{H}), 7.36-7.28(\mathrm{~m}, 9 \mathrm{H}), 4.74(\mathrm{t}, J=$ $7.9 \mathrm{~Hz}, 1 \mathrm{H}), 4.56-4.49(\mathrm{~m}, 3 \mathrm{H}), 4.44-4.30(\mathrm{~m}, 3 \mathrm{H}), 4.23(\mathrm{~d}, J=$ $10.9 \mathrm{~Hz}, 1 \mathrm{H}), 4.06(\mathrm{~d}, J=11.3 \mathrm{~Hz}, 1 \mathrm{H}), 4.01(\mathrm{~d}, J=15.7 \mathrm{~Hz}, 1 \mathrm{H})$, $3.98-3.92(\mathrm{~m}, 2 \mathrm{H}), 3.81-3.72(\mathrm{~m}, 2 \mathrm{H}), 3.69-3.59(\mathrm{~m}, 10 \mathrm{H}), 2.65$ $(\mathrm{s}, 3 \mathrm{H}), 2.53-2.45(\mathrm{~m}, 4 \mathrm{H}), 2.41(\mathrm{~s}, 3 \mathrm{H}), 2.18-2.09(\mathrm{~m}, 2 \mathrm{H}), 1.73-$ $1.62(\mathrm{~m}, 4 \mathrm{H}), 1.01(\mathrm{t}, J=7.4 \mathrm{~Hz}, 3 \mathrm{H}), 0.95 \mathrm{ppm}(\mathrm{s}, 9 \mathrm{H}) ;{ }^{13} \mathrm{C} \mathrm{NMR}$ $\left(126 \mathrm{MHz}, \mathrm{CDCl}_{3}\right): \delta 174.8,171.4,171.1,170.5,163.2,162.9,154.5$, $150.5,149.9,148.5,138.4,136.9,136.6,132.1,131.8,131.1,131.0$, $130.9,130.7,130.0,129.6,128.8,128.2,71.3,70.9,70.8,70.6,70.5$, $70.2,69.3,63.8,59.3,58.7,57.2,56.8,49.7,43.3,36.2,35.3,26.5$, $23.3,16.1,14.5,13.2,11.9,11.7$; HRMS $m / z$ : calcd for $\mathrm{C}_{51} \mathrm{H}_{64} \mathrm{ClN}_{8} \mathrm{O}_{9} \mathrm{~S}_{2}[\mathrm{M}+\mathrm{H}]^{+}, 1031.3921$; found, 1031.3961 .

4.1.29. 2-(3-(2-)((S)-1-((2S,4R)-4-Hydroxy-2-(((S)-1-(4-(4-methylthiazol-5-yl)phenyl)ethyl)carbamoyl)pyrrolidin-1-yl)-3,3-dimethyl1-oxobutan-2-yl)amino)-2-oxoethoxy)propoxy)ethyl (R)-2-((S)-4(4-chlorophenyl)-2,3,9-trimethyl-6H-thieno[3,2-f][1,2,4]triazolo$[4,3-a][1,4]$ diazepin-6-yl)butanoate (AGB2) (47). Following general procedure $\mathrm{F}$, compound 47 was obtained using alcohol 44 (synthesized according to the literature ${ }^{30}$ ) and purified by HPLC using a linear gradient from 5 to $95 \% \mathrm{MeCN}$ in $0.1 \%$ formic acid over $12 \mathrm{~min}$ in water to afford AGB2 (47). Yield: $1.2 \mathrm{mg}(10 \%) ;{ }^{1} \mathrm{H}$ NMR $\left(500 \mathrm{MHz}, \mathrm{CDCl}_{3}\right): \delta 8.66(\mathrm{~s}, 1 \mathrm{H}), 7.47(\mathrm{~d}, J=7.3 \mathrm{~Hz}, 1 \mathrm{H}), 7.39(\mathrm{~d}$, $J=8.4 \mathrm{~Hz}, 2 \mathrm{H}), 7.36(\mathrm{~d}, J=8.4 \mathrm{~Hz}, 2 \mathrm{H}), 7.33(\mathrm{~d}, J=8.5 \mathrm{~Hz}, 2 \mathrm{H})$, $7.29(\mathrm{~d}, J=8.8 \mathrm{~Hz}, 2 \mathrm{H}), 7.20(\mathrm{~d}, J=8.6 \mathrm{~Hz}, 1 \mathrm{H}), 5.08(\mathrm{dq}, J=7.2$, $7.2 \mathrm{~Hz}, 1 \mathrm{H}), 4.78(\mathrm{t}, J=7.9 \mathrm{~Hz}, 1 \mathrm{H}), 4.56(\mathrm{~d}, J=8.6 \mathrm{~Hz}, 1 \mathrm{H}), 4.55-$ $4.51(\mathrm{~m}, 1 \mathrm{H}), 4.49-4.43(\mathrm{~m}, 1 \mathrm{H}), 4.35-4.30(\mathrm{~m}, 1 \mathrm{H}), 4.25(\mathrm{~d}, J=$ $10.8 \mathrm{~Hz}, 1 \mathrm{H}), 4.12(\mathrm{~d}, J=11.3 \mathrm{~Hz}, 1 \mathrm{H}), 4.00-3.93(\mathrm{~m}, 2 \mathrm{H}), 3.87(\mathrm{~d}$, $J=15.4 \mathrm{~Hz}, 1 \mathrm{H}), 3.80-3.75(\mathrm{~m}, 1 \mathrm{H}), 3.75-3.69(\mathrm{~m}, 1 \mathrm{H}), 3.64-3.58$ $(\mathrm{m}, 5 \mathrm{H}), 2.65(\mathrm{~s}, 3 \mathrm{H}), 2.58-2.52(\mathrm{~m}, 4 \mathrm{H}), 2.41(\mathrm{~s}, 3 \mathrm{H}), 2.20-2.12$ $(\mathrm{m}, 1 \mathrm{H}), 2.09(\mathrm{dd}, J=8.3,13.6 \mathrm{~Hz}, 1 \mathrm{H}), 1.93-1.86(\mathrm{~m}, 2 \mathrm{H}), 1.73-$ $1.63(\mathrm{~m}, 4 \mathrm{H}), 1.47(\mathrm{~d}, J=6.9 \mathrm{~Hz}, 3 \mathrm{H}), 1.06(\mathrm{~s}, 9 \mathrm{H}), 1.02 \mathrm{ppm}(\mathrm{t}, J=$ $7.4 \mathrm{~Hz}, 3 \mathrm{H}) ;{ }^{13} \mathrm{C}$ NMR $\left(126 \mathrm{MHz}, \mathrm{CDCl}_{3}\right): \delta 174.9,171.8,170.4$, $169.8,163.2,154.6,150.3,149.9,148.7,143.4,136.9,136.6,131.02$, $130.99,130.0,129.7,128.8,126.6,70.3,70.2,69.0,68.9,68.0,63.8$, 59.4, 58.5, 57.1, 56.8, 49.8, 49.0, 35.6, 35.2, 30.0, 29.8, 26.7, 23.4, $22.4,16.2,14.6,13.3,11.9,11.7$; HRMS $m / z$ : calcd for $\mathrm{C}_{51} \mathrm{H}_{64} \mathrm{ClN}_{8} \mathrm{O}_{8} \mathrm{~S}_{2}[\mathrm{M}+\mathrm{H}]^{+}, 1015.3972$; found, 1015.4197 .

4.1.30. (2S,4R)-1-((2S,17R)-2-(tert-Butyl)-17-((S)-4-(4-chlorophenyl)-2,3,9-trimethyl-6H-thieno[3,2-f][1,2,4]triazolo [4,3-a][1,4]diazepin-6-yl)-4,16-dioxo-6,9,12-trioxa-3,15-diazanonadecanoyl)4-hydroxy-N-(4-(4-methylthiazol-5-yl)benzyl)pyrrolidine-2-carboxamide (AGB3) (48). Azide 9 (synthesized according to the literature $\left.^{14}\right)(30 \mathrm{mg}, 46 \mu \mathrm{mol})$ was dissolved in $\mathrm{MeOH}(2 \mathrm{~mL})$. A catalytic amount of $10 \mathrm{wt} \% \mathrm{Pd} / \mathrm{C}$ was added, and the reaction was stirred under an atmosphere of hydrogen for $3 \mathrm{~h}$. The reaction mixture was then filtered through PTFE syringe filters and evaporated to dryness to obtain the desired amine quantitative yields. The resulting amine $(7.4 \mathrm{mg}, 12 \mu \mathrm{mol})$ was dissolved in DMF $(96 \mu \mathrm{L})$ and added to a solution of ET-JQ1-OH (45, synthesized according to the literature $\left.^{21}\right)(5 \mathrm{mg}, 12 \mu \mathrm{mol})$, COMU $(5.1 \mathrm{mg}, 12 \mu \mathrm{mol})$ and DIPEA $(4.18 \mu \mathrm{L}, 12 \mu \mathrm{mol})$ in DMF $(96 \mu \mathrm{L})$ and stirred at r.t. for $2 \mathrm{~h}$. The mixtures were then concentrated in vacuo, and the residues were purified by HPLC using a linear gradient of $5-95 \% \mathrm{MeCN}$ in $0.1 \%$ formic acid in water over $12 \mathrm{~min}$ to afford AGB3 (48). Yield: $2.2 \mathrm{mg}$ 
$(18 \%) ;{ }^{1} \mathrm{H}$ NMR $\left(400 \mathrm{MHz}, \mathrm{CDCl}_{3}\right): \delta 8.68(\mathrm{~s}, 1 \mathrm{H}), 8.18(\mathrm{t}, J=5.5$ $\mathrm{Hz}, 1 \mathrm{H}), 7.36(\mathrm{~d}, J=8.3 \mathrm{~Hz}, 2 \mathrm{H}), 7.31-7.24(\mathrm{~m}, 5 \mathrm{H}), 7.17-7.12(\mathrm{~m}$, $3 \mathrm{H}), 4.99(\mathrm{~d}, J=4.9 \mathrm{~Hz}, 1 \mathrm{H}), 4.85(\mathrm{t}, J=8.2 \mathrm{~Hz}, 1 \mathrm{H}), 4.80(\mathrm{~d}, J=9.7$ $\mathrm{Hz}, 1 \mathrm{H}), 4.51(\mathrm{br} \mathrm{s}, 1 \mathrm{H}), 4.46(\mathrm{dd}, J=7.2,15.8 \mathrm{~Hz}, 1 \mathrm{H}), 4.26(\mathrm{~d}, J=$ $10.5 \mathrm{~Hz}, 1 \mathrm{H}), 4.19-4.11(\mathrm{~m}, 2 \mathrm{H}), 4.09(\mathrm{~d}, J=15.9 \mathrm{~Hz}, 1 \mathrm{H}), 3.83-$ $3.63(\mathrm{~m}, 15 \mathrm{H}), 3.50-3.42(\mathrm{~m}, 1 \mathrm{H}), 2.64(\mathrm{~s}, 3 \mathrm{H}), 2.53(\mathrm{~s}, 3 \mathrm{H}), 2.39$ (s, 3H), 2.34-2.27 (m, 1H), $2.16(\mathrm{dd}, J=7.5,13.5 \mathrm{~Hz}, 1 \mathrm{H}), 1.96-$ $1.89(\mathrm{~m}, 1 \mathrm{H}), 1.64-1.56(\mathrm{~m}, 4 \mathrm{H}), 1.03-0.96 \mathrm{ppm}(\mathrm{m}, 12 \mathrm{H}) ;{ }^{13} \mathrm{C}$ NMR $\left(101 \mathrm{MHz}, \mathrm{CDCl}_{3}\right): \delta 173.8,171.7,171.6,170.3,163.9,155.0$, $150.3,149.9,148.5,138.6,136.9,136.7,132.0,131.9,131.31,131.28$, $130.9,130.6,130.1,129.4,129.0,127.5,71.3,71.1,70.75,70.69,70.4$, $70.3,59.8,59.4,57.7,56.7,50.3,42.9,39.8,36.9,36.0,26.6,23.1$, 16.2, 14.6, 13.3, 12.0, 11.9; HRMS $m / z$ : calcd for $\mathrm{C}_{51} \mathrm{H}_{65} \mathrm{ClN}_{9} \mathrm{O}_{8} \mathrm{~S}_{2}$ $[\mathrm{M}+\mathrm{H}]^{+}, 1030.4081$; found, 1030.4589 .

4.1.31. (2S,4S)-1-((S)-17-(tert-Butyl)-2,2-dimethyl-15-oxo-3,3-diphenyl-4,7,10,13-tetraoxa-16-aza-3-silaoctadecan-18-oyl)-4-hydroxy-N-(4-(4-methylthiazol-5-yl)benzyl)pyrrolidine-2-carboxamide (50). Acid 37 (synthesized according to the literature $\left.{ }^{30}\right)(161$ $\mathrm{mg}, 0.36 \mathrm{mmol})$, COMU (154 mg, $0.36 \mathrm{mmol})$, and DIPEA (334 $\mu \mathrm{L}$, $1.92 \mathrm{mmol})$ were dissolved in DMF $(1.92 \mathrm{~mL})$ and stirred at r.t. for $10 \mathrm{~min}$. Amine 49 (synthesized according to the literature ${ }^{14}$ ) (112 $\mathrm{mg}, 0.24 \mathrm{mmol}$ ) was added, and the reaction was left to stir at r.t. for 2 h. The mixture was then purified by reversed-phase flash column chromatography $(2 \times 15.5 \mathrm{~g} \mathrm{C18}$ column $)$ using a linear gradient from 5 to $100 \% \mathrm{MeCN}$ in $0.1 \%$ formic acid in water over $10 \mathrm{~min}$ with a 3 min plateau to afford 50. Yield: $103 \mathrm{mg}(50 \%) ;{ }^{1} \mathrm{H}$ NMR (500 $\left.\mathrm{MHz}, \mathrm{CDCl}_{3}\right): \delta 8.65(\mathrm{~s}, 1 \mathrm{H}), 7.69-7.65(\mathrm{~m}, 4 \mathrm{H}), 7.57(\mathrm{t}, J=6.1 \mathrm{~Hz}$, $1 \mathrm{H}), 7.43-7.31(\mathrm{~m}, 10 \mathrm{H}), 7.20(\mathrm{~d}, J=9.1 \mathrm{~Hz}, 1 \mathrm{H}), 5.52(\mathrm{~d}, J=9.8$ $\mathrm{Hz}, 1 \mathrm{H}), 4.71(\mathrm{~d}, J=9.0 \mathrm{~Hz}, 1 \mathrm{H}), 4.60(\mathrm{dd}, J=7.0,14.9 \mathrm{~Hz}, 1 \mathrm{H})$, $4.52(\mathrm{~d}, J=9.1 \mathrm{~Hz}, 1 \mathrm{H}), 4.49-4.43(\mathrm{~m}, 1 \mathrm{H}), 4.29(\mathrm{dd}, J=5.1,14.9$ $\mathrm{Hz}, 1 \mathrm{H}), 4.01(\mathrm{~d}, J=15.6 \mathrm{~Hz}, 1 \mathrm{H}), 3.98-3.91(\mathrm{~m}, 2 \mathrm{H}), 3.82-3.77$ $(\mathrm{m}, 3 \mathrm{H}), 3.70-3.59(\mathrm{~m}, 8 \mathrm{H}), 3.57(\mathrm{t}, J=5.4 \mathrm{~Hz}, 2 \mathrm{H}), 2.50(\mathrm{~s}, 3 \mathrm{H})$, $2.34(\mathrm{~d}, J=14.0 \mathrm{~Hz}, 1 \mathrm{H}), 2.19-2.10(\mathrm{~m}, 1 \mathrm{H}), 1.04(\mathrm{~s}, 9 \mathrm{H}), 0.93 \mathrm{ppm}$ (s, 9H); ${ }^{13} \mathrm{C}$ NMR $\left(126 \mathrm{MHz}, \mathrm{CDCl}_{3}\right): 172.7,171.9,169.9,150.4$, $148.7,137.5,135.7,133.8,131.6,131.3,129.7,128.3,127.7,72.6$, $71.3,71.2,70.9,70.8,70.54,70.51,63.5,60.0,58.7,56.6,43.6,35.2$, $35.1,30.4,26.9,26.4,19.3,16.1$; LCMS $\mathrm{m} / z$ : calcd for $\mathrm{C}_{46} \mathrm{H}_{63} \mathrm{~N}_{4} \mathrm{O}_{8} \mathrm{SSi}[\mathrm{M}+\mathrm{H}]^{+}, 859.4$; found, 859.3.

4.1.32. (2S,4S)-1-((S)-2-(tert-Butyl)-14-hydroxy-4-oxo-6,9,12-trioxa-3-azatetradecanoyl)-4-hydroxy-N-(4-(4-methylthiazol-5-yl)benzyl)pyrrolidine-2-carboxamide (51). To a solution of compound $50(51 \mathrm{mg}, 59 \mu \mathrm{mol})$ in THF $(11.9 \mathrm{~mL})$ was added a $1.0 \mathrm{M}$ solution of TBAF in THF (178 $\mu \mathrm{L}, 178 \mu \mathrm{mol})$. This was left to stir for $6 \mathrm{~h}$. The mixture was then concentrated in vacuo, and the residue was purified by reversed-phase flash column chromatography (15.5 g C18 column) using a linear gradient from 5 to $100 \% \mathrm{MeCN}$ in $0.1 \%$ formic acid in water over $10 \mathrm{~min}$ to afford alcohol 51. Yield: $36.6 \mathrm{mg}$ (quant.); ${ }^{1} \mathrm{H} \mathrm{NMR}\left(500 \mathrm{MHz}, \mathrm{CDCl}_{3}\right): \delta 8.66(\mathrm{~s}, 1 \mathrm{H}), 8.01(\mathrm{t}, J=$ $5.9 \mathrm{~Hz}, 1 \mathrm{H}), 7.38-7.32(\mathrm{~m}, 4 \mathrm{H}), 7.29(\mathrm{~d}, J=9.4 \mathrm{~Hz}, 1 \mathrm{H}), 4.67(\mathrm{~d}, J$ $=8.7 \mathrm{~Hz}, 1 \mathrm{H}), 4.64-4.58(\mathrm{~m}, 2 \mathrm{H}), 4.44(\mathrm{t}, J=4.3 \mathrm{~Hz}, 1 \mathrm{H}), 4.30(\mathrm{dd}$, $J=5.1,15.0 \mathrm{~Hz}, 1 \mathrm{H}), 4.04(\mathrm{~d}, J=15.6 \mathrm{~Hz}, 1 \mathrm{H}), 3.97(\mathrm{~d}, J=15.3 \mathrm{~Hz}$, $1 \mathrm{H}), 3.89(\mathrm{dd}, J=4.2,10.9 \mathrm{~Hz}, 1 \mathrm{H}), 3.84(\mathrm{~d}, J=10.7 \mathrm{~Hz}, 1 \mathrm{H}), 3.71-$ $3.52(\mathrm{~m}, 12 \mathrm{H}), 3.51-3.44(\mathrm{~m}, 1 \mathrm{H}), 2.50(\mathrm{~s}, 3 \mathrm{H}), 2.26(\mathrm{~d}, J=14.3$ $\mathrm{Hz}, 1 \mathrm{H}), 2.23-2.15$ (m, 1H), $0.96 \mathrm{ppm}(\mathrm{s}, 9 \mathrm{H}) ; 172.8,171.8,169.8$, 150.4, 148.6, 137.7, 131.7, 131.2, 129.6, 128.2, 72.7, 71.2, 71.1, 70.9, 70.5, 70.35, 70.29, 61.7, 60.1, 58.8, 56.5, 43.6, 35.7, 35.5, 26.4, 16.1; LCMS $m / z$ : calcd for $\mathrm{C}_{30} \mathrm{H}_{45} \mathrm{~N}_{4} \mathrm{O}_{8} \mathrm{~S}[\mathrm{M}+\mathrm{H}]^{+}, 621.3$; found, 621.2. 4.1.33. (S)-13-((2S,4S)-4-Hydroxy-2-((4-(4-methylthiazol-5-yl)benzyl)carbamoyl)pyrrolidine-1-carbonyl)-14,14-dimethyl-11-oxo3,6,9-trioxa-12-azapentadecyl (R)-2-((S)-4-(4-chlorophenyl)-2,3,9trimethyl-6H-thieno[3,2-f][1,2,4]triazolo[4,3-a][1,4]diazepin-6-yl)butanoate (cis-AGB1) (52). Following general procedure $\mathrm{F}$, compound 52 was obtained using alcohol 51 and purified by HPLC using a linear gradient from 5 to $95 \% \mathrm{MeCN}$ in $0.1 \%$ formic acid in water over $12 \mathrm{~min}$ to afford cis-AGB1 (52). Yield: $8.4 \mathrm{mg}$ (51\%); ${ }^{1} \mathrm{H}$ NMR (500 MHz, $\left.\mathrm{CDCl}_{3}\right): \delta 8.67(\mathrm{~s}, 1 \mathrm{H}), 7.63(\mathrm{t}, J=5.8$ $\mathrm{Hz}, 1 \mathrm{H}), 7.38-7.27(\mathrm{~m}, 8 \mathrm{H}), 7.18(\mathrm{~d}, J=9.3 \mathrm{~Hz}, 1 \mathrm{H}), 5.54(\mathrm{~d}, J=$ $10.1 \mathrm{~Hz}, 1 \mathrm{H}), 4.75(\mathrm{~d}, J=9.1 \mathrm{~Hz}, 1 \mathrm{H}), 4.61(\mathrm{dd}, J=7.0,14.9 \mathrm{~Hz}$, $1 \mathrm{H}), 4.54(\mathrm{~d}, J=9.2 \mathrm{~Hz}, 1 \mathrm{H}), 4.49-4.33(\mathrm{~m}, 3 \mathrm{H}), 4.30(\mathrm{dd}, J=5.3$, $15.0 \mathrm{~Hz}, 1 \mathrm{H}), 4.24(\mathrm{~d}, J=10.9 \mathrm{~Hz}, 1 \mathrm{H}), 4.01(\mathrm{~d}, J=15.8 \mathrm{~Hz}, 1 \mathrm{H})$, $3.99-3.91(\mathrm{~m}, 3 \mathrm{H}), 3.81(\mathrm{~d}, J=11.1 \mathrm{~Hz}, 1 \mathrm{H}), 3.79-3.75(\mathrm{~m}, 2 \mathrm{H})$,
3.70-3.62 (m, 8H), $2.65(\mathrm{~s}, 3 \mathrm{H}), 2.51(\mathrm{~s}, 3 \mathrm{H}), 2.41(\mathrm{~s}, 3 \mathrm{H}), 2.34(\mathrm{~d}$, $J=14.3 \mathrm{~Hz}, 1 \mathrm{H}), 2.21-2.13(\mathrm{~m}, 2 \mathrm{H}), 1.72-1.64(\mathrm{~m}, 4 \mathrm{H}), 1.02(\mathrm{t}, J=$ $7.5,3 \mathrm{H}), 0.95 \mathrm{ppm}(\mathrm{s}, 9 \mathrm{H}) ;{ }^{13} \mathrm{C} \mathrm{NMR}\left(126 \mathrm{MHz} \mathrm{CDCl}_{3}\right): \delta 174.9$, $172.9,171.7,169.9,163.2,154.5,150.5,149.9,148.6,137.6,136.8$, $136.5,132.1,131.6,131.2,131.0,130.9,130.5,130.0,129.7,128.8$, $128.3,71.3,71.2,70.84,70.81,70.5,69.3,63.8,60.0,59.3,58.7,56.5$, 49.8, 43.6, 35.30, 35.26, 26.4, 23.3, 16.2, 14.6, 13.3, 12.0, 11.7; HRMS $m / z$ : calcd for $\mathrm{C}_{51} \mathrm{H}_{64} \mathrm{ClN}_{8} \mathrm{O}_{9} \mathrm{~S}_{2}[\mathrm{M}+\mathrm{H}]^{+}, 1031.3921$; found, 1031.3987.

4.2. Biology. 4.2.1. Cell Culture. The HEK293 human embryonic kidney adherent cell line (ATCC, Manassas, VA, USA) was cultured in Dulbecco's modified Eagle's medium (DMEM) (Invitrogen, Carlsbad, CA, USA) supplemented with $10 \%(\mathrm{v} / \mathrm{v})$ fetal bovine serum (FBS) (Thermo Fisher, Waltham, MA, USA) and 1\% (v/v) penicillin/streptomycin (pen/strep) (\#15140122, Thermo Fisher, Waltham, MA, USA) at $37^{\circ} \mathrm{C}, 5 \% \mathrm{CO}_{2}$, and $95 \%$ humidity. $22 \mathrm{RV} 1$; a human prostate carcinoma epithelial adherent cell line (ATCC, Manassas, VA, USA) was cultured in RPMI-1640 (Invitrogen, Carlsbad, CA, USA) supplemented with $10 \%$ (v/v) FBS (Thermo Fisher, Waltham, MA, USA) and $1 \%(\mathrm{v} / \mathrm{v})$ penicillin/streptomycin (pen/strep) (\#15140122, Thermo Fisher, Waltham, MA, USA) at 37 ${ }^{\circ} \mathrm{C}, 5 \% \mathrm{CO}_{2}$, and $95 \%$ humidity. The MV-4-11 human acute monocytic leukemia suspension cell line (ATCC, Manassas, VA, USA) was cultured in IMDM (Invitrogen, Carlsbad, CA, USA) supplemented with $10 \%(\mathrm{v} / \mathrm{v})$ FBS (Thermo Fisher, Waltham, MA, USA) and $1 \%(\mathrm{v} / \mathrm{v})$ penicillin/streptomycin (pen/strep) (\#15140122, Thermo Fisher, Waltham, MA, USA) at $37{ }^{\circ} \mathrm{C}, 5 \%$ $\mathrm{CO}_{2}$, and $95 \%$ humidity.

4.2.2. CRISPR BromoTag-Brd2 Knock-In Cell Line Generation. HEK293 cells were maintained in DMEM (Invitrogen, Carlsbad, CA, USA) supplemented with $10 \%(\mathrm{v} / \mathrm{v})$ FBS (Thermo Fisher, Waltham, MA, USA) and $1 \%(\mathrm{v} / \mathrm{v})$ penicillin/streptomycin (pen/strep) (\#15140122, Thermo Fisher, Waltham, MA, USA) at $37{ }^{\circ} \mathrm{C}, 5 \%$ $\mathrm{CO}_{2}$, and $95 \%$ humidity. HEK293 cells $(50,000)$ were plated into individual wells of a six-well plate in $1 \mathrm{~mL}$ of DMEM (Invitrogen, Carlsbad, CA, USA) for $24 \mathrm{~h}$, leading up to the initiation of the experiment. HEK293 cells were transfected using a Fugene HD transfection reagent (Madison, Wisconsin, United States) or lipofectamine 2000 (Madison, Wisconsin, United States) simultaneously with three custom vectors including a $\mathrm{px3} 35$ vector (Addgene) containing a U6-snRNA \& Cas9D10A expression cassette, a pBABED vector (MRC PPU, Dundee University) harboring another U6-sgRNA and puromycin expression cassette, and finally a pcDNA5 vector containing an eGFP-P2A-BromoTag-Brd2 donor knock-in sequence. DNA fragment encoding for the selected guide RNA sequences (BRD2-KI-1-s: AGGGCAGCGCCGGTTCCTTGCGG; BRD2-KI-2as: TCAGCCGCGGAAAGTCCGGGTGG) was cloned into plasmid pX335 and a custom-made pBABE-Puromycin vector anchoring a pU6 promoter, respectively, to provide the source of guide RNAs. The donor DNA was designed by having a DNA sequence $500 \mathrm{bp}$ upstream and $500 \mathrm{bp}$ downstream of the designated tag insertion site of BRD2 (Entrez GeneID: 6046) forming a pair of homology arm flanking DNA sequence encoding for GFP-P2A-BromoTag. The donor DNA was obtained in the format of plasmid DNA by gene synthesis service from GeneART. To increase the relative population of cells undergoing homologous recombination, this transfection was performed in the presence of $0.1 \mu \mathrm{M}$ of the DNA ligase IV inhibitor SCR7. The following day, cells were washed before applying fresh DMEM containing $0.1 \mu \mathrm{M}$ of SCR7 and $2 \mu \mathrm{g} / \mathrm{mL}$ of puromycin. This was repeated the following day as cells were washed before applying fresh DMEM containing $0.1 \mu \mathrm{M}$ of SCR7 and $2 \mu \mathrm{g} / \mathrm{mL}$ of puromycin. The following day, the cells were washed for the third time, and fresh media without both SCR7 and puromycin was applied to allow for recovery. The following day, HEK293 cells were washed and then cultured with fresh DMEM containing $2.5 \mu \mathrm{g} / \mathrm{mL}$ of puromycin and $0.1 \mu \mathrm{M}$ of SCR7. This process was continued for a further 2 days. The cells were then washed with PBS before recovery in DMEM was performed for a further 20 days. The cells were subsequently prepared for FACS sorting. 
4.2.3. FACS of GFP-Positive CRISPR Knock-In BromoTag-Brd2 HEK293 Cells. HEK293 cells that had undergone CRISPR lipofection and selection in the previous stage were subsequently trypsinized using trypsin-EDTA (0.05\%) and phenol red (Thermo Fisher, Waltham, MA, USA). Once in suspension, the trypsin-cell mixture was neutralized with FBS (Thermo Fisher, Waltham, MA, USA). Cells were pelleted at $1500 \mathrm{rpm}$ for $5 \mathrm{~min}$. The cell pellet produced was subsequently resuspended in DMEM supplemented with 1\% FBS at a concentration of $5 \times 10^{6}$ cells per mL. Wild-type HEK293 cells were used as a baseline control for GFP expression. Single-cell clones were generated by FACS using an SH800 cell sorter from Sony Biotechnology of the Dundee University Flow Cytometry and Cell Sorting Facility. A $488 \mathrm{~nm}$ laser was used for the excitation of fluorescence and generation of light scattering. Forward angle light scatter (FSC) and backscatter were detected using $488 \pm 17 \mathrm{~nm}$ band-pass filters. Cells were distinguished from debris on the basis of FSC-area (A) and SSC-A measurements. Single cells were distinguished from doublets and clumps on the basis of FSC-A and FSC-width (W) measurements. GFP fluorescence was detected using a $525 \pm 50 \mathrm{~nm}$ band-pass filter, and autofluorescence was detected using a $600 \pm 60 \mathrm{~nm}$ band-pass filter. GFP-positive cells were identified by first assessing the background GFP and autofluorescence of a control sample of cells which did not express GFP. Using the measurements for GFP and autofluorescence of this sample, a collection gate was set, which identified GFP-positive cells. The samples to be sorted were then analyzed, and GFP-positive cells were sorted for collection.

A single GFP +ve cell was sorted into each well of a $3 \times 96$ well plate (Thermo Fisher, Waltham, MA, USA) in $200 \mu \mathrm{L}$ of $50 \%$ filtered preconditioned media from healthy cells and 50\% fresh DMEM containing $10 \% \mathrm{FBS}$ and $1 \%(\mathrm{v} / \mathrm{v})$ penicillin/streptomycin (pen/ strep) (\#15140122, Thermo Fisher, Waltham, MA, USA) and stored at $37{ }^{\circ} \mathrm{C}, 5 \% \mathrm{CO}_{2}$, and $95 \%$ humidity for 2 weeks. After 2 weeks, all visible colonies were expanded and subsequently frozen down.

4.2.4. Genomic DNA Extraction. The Brd2 expression in the postexpanded cell lines was analyzed via western blot, and potentially positive cell lines were subsequently harvested for genomic extraction. Cells were plated at a density of $2 \times 10^{6}$ cells in the well of a $10 \mathrm{~cm}$ plate. After $48 \mathrm{~h}$, the cells were trypsinized using trypsin-EDTA (0.05\%) and phenol red (Thermo Fisher, Waltham, MA, USA). Once in suspension, the trypsin-cell mixture was neutralized with FBS (Thermo Fisher, Waltham, MA, USA). The cells were pelleted at $1500 \mathrm{rpm}$ for $5 \mathrm{~min}$. The remaining pellet of each clone underwent genomic extraction following a solution-based extraction approach using PROMEGA's Wizard Genomic DNA Purification Kit following the instruction provided. The DNA extracted was subsequently analyzed using a NanoDrop spectrophotometer and stored at $-20{ }^{\circ} \mathrm{C}$ prior to use.

4.2.5. Junction $P C R$. Junction PCR was performed using the following primers: forward, AGTCTGTCCACCCCCTCTAC, and reverse, ACTCCACTCCACCGTCAAAC. The extracted genomic DNA from the previous step was used as the template for a subsequent PCR reaction. Using Phusion high-fidelity polymerase and $250 \mathrm{ng}$ of template DNA of either clone or HEK293 wild-type genomic DNA, a 30-cycle PCR was run with a melting temperature of $98{ }^{\circ} \mathrm{C}$, an annealing temperature of $60{ }^{\circ} \mathrm{C}$, and a 2 min elongation step at $72{ }^{\circ} \mathrm{C}$. The product of these PCRs was then subsequently run on a $2 \%$ agarose gel containing $1 \times$ Sybersafe DNA staining reagent (Invitrogen, Carlsbad, CA, USA) in a $1 \times$ DNA loading dye (Thermo Fisher, Waltham, MA, USA) along with a $1 \times$ GeneRuler $1 \mathrm{~kb}$ plus DNA marker (Thermo Fisher, Waltham, MA, USA) at $100 \mathrm{~V}$ for 30 min. The run gel was imaged using a Bio-Rad Gel Doc system (BioRad, Hercules, California).

4.2.6. Genotyping. Using the agarose gel containing the junction PCR product, appropriately sized bands from that agarose gel were harvested using a UV imager and a scalpel. The bands chosen corresponded to the HEK293 wild-type Brd2 junction product $1 \mathrm{~kb}$, the BromoTag-Brd2 clone wild-type Brd2 junction product $1 \mathrm{~kb}$, and the BromoTag-Brd2 clone Knock-in junction product $2 \mathrm{~kb}$. The excised bands were subsequently removed from the agarose using a
Monarch DNA Gel Extraction Kit (NEB, Ipswich, Massachusetts). Following extraction, the PCR product was ligated into blunt-end vectors using a StrataClone Blunt PCR Cloning kit (Agilent, Santa Clara, California) and subsequently transformed into Cre recombinase expressing E. coli (Agilent, Santa Clara, California) and plated onto kanamycin $50 \mu \mathrm{g} / \mathrm{mL}$ agar plates. A day following plating, visible colonies were picked and grown for $16 \mathrm{~h}$ in $5 \mathrm{~mL}$ of kanamycin 50 $\mu \mathrm{g} / \mathrm{mL}$ containing LB standard formula. The subsequent overnight bacterial growth underwent plasmid miniprep extraction using the Monarch Plasmid Miniprep Kit (NEB, Ipswich, Massachusetts). The vector product recovered after extraction was subsequently analyzed using a NanoDrop spectrophotometer. These products underwent sequencing using an Applied Biosystems 3730 DNA analyzer using commercially available M13-forward, M13-reverse, and eGFP-C1forward primers. The sequencing was performed by DNA sequencing and services from the University of Dundee. The raw data from sequencing was subsequently analyzed using Jalview software.

4.2.7. Dose-Response Degradation Assays. All dose-response degradation assays were performed on the genotype-verified heterozygous BromoTag-Brd2 HEK293 cell line. Heterozygous BromoTag-Brd2 HEK293 cells were plated at a density of $5 \times 10^{5}$ cells per well of a six-well healthy plate a day before initiation of the titration experiment. PROTAC compounds were dissolved in DMSO at a concentration of $10 \mathrm{mM}$; from these stock concentrations, PROTAC compounds were diluted to appropriate concentrations using DMSO in the range of $10 \mu \mathrm{M}$ to $1 \mathrm{nM}$. The compounds were then added to $2 \mathrm{~mL}$ of DMEM (Invitrogen, Carlsbad, CA, USA) supplemented with $10 \%(\mathrm{v} / \mathrm{v})$ FBS (Thermo Fisher, Waltham, MA, USA) and $1 \%(\mathrm{v} / \mathrm{v})$ penicillin/streptomycin (pen/strep) (\#15140122, Thermo Fisher, Waltham, MA, USA) and added to the cells while initiating the experiment. Control compounds such as MZ1 and cis-MZ1 were similarly dissolved in DMSO to an appropriate concentration. All titration experiments were performed for a total of $6 \mathrm{~h}$ prior to being harvested and were kept at $37^{\circ} \mathrm{C}, 5 \%$ $\mathrm{CO}_{2}$, and $95 \%$ humidity once treatment was applied until right before harvesting. The cells were washed twice with PBS before being harvested.

4.2.8. Time Course Degradation Assay. Time course degradation assays using PROTACs AGB1 (46), AGB2 (47), and AGB3 (48) were performed on the genotype-verified heterozygous BromoTagBrd2 HEK293 cell line. Heterozygous BromoTag-Brd2 HEK293 cells were plated at a density of $5 \times 10^{5}$ cells per well of a six-well healthy plate a day prior to initiating the time course assay. PROTAC's AGB1 (46) and AGB2 (47) were diluted in DMSO to a concentration of 1 $\mathrm{mM}$ prior to being further diluted 1:2000 in $2 \mathrm{~mL}$ of DMEM to a concentration of $500 \mathrm{nM}$ per time point. PROTAC AGB3 (48) was diluted in DMSO to a concentration of $2 \mathrm{mM}$ prior to being further diluted 1:2000 in $2 \mathrm{~mL}$ of DMEM to a concentration of $1 \mu \mathrm{M}$ per time point. The time point range was between 0 and $36 \mathrm{~h}$. Treatment was applied in a staggered fashion to enable all time points to be harvested at the same time.

4.2.9. Recovery Assay. A recovery assay was performed using 200 $\mathrm{nM}$ of AGB1 (46) over a $72 \mathrm{~h}$ period. This was performed in the genotype-verified heterozygous BromoTag-Brd2 HEK293 cell line. Heterozygous BromoTag-Brd2 HEK293 cells were plated at a density of $5 \times 10^{5}$ cells per well of a six-well plate a day before initiating the recovery assay. On the experiment day, the cells were washed with PBS before fresh DMEM containing either $200 \mathrm{nM}$ of DMSO or AGB1 (46) was applied. During treatment, the cells were kept at 37 ${ }^{\circ} \mathrm{C}, 5 \% \mathrm{CO}_{2}$, and $95 \%$ humidity. After $3 \mathrm{~h}$, the recovery and vehicle control condition cells were rewashed with PBS before fresh DMEM without $200 \mathrm{nM}$ of AGB1 (46) or DMSO was applied. As for the positive control condition, they were left with 200 nM AGB1 (46) for the remainder of the treatment time.

4.3. Acquisition of the Polyclonal Brd4 $4^{\mathrm{BD} 2 \mathrm{~L} 387 \mathrm{~A}}$ Antibody. The sheep polyclonal antibody for Brd4 $4^{\mathrm{BD} 2 \mathrm{~L} 387 \mathrm{~A}}$ (SA599, bleed \#4 used in the assays) was generated by MRC Reagents and Services (https://mrcppureagents.dundee.ac.uk/). To generate the polyclonal antibody, a sheep was immunized with $0.35 \mathrm{mg}$ of His-Brd4 ${ }^{\mathrm{BD} 2} \mathrm{~L} 387 \mathrm{~A}$ domain protein purified as previously described ${ }^{15,18}$ and prepared in a 
buffer containing $20 \mathrm{mM}$ HEPES pH7.5, 0.5 M NaCl, and $1 \mathrm{mM}$ DTT. This was followed by four further injections 28 days apart. Bleeding assessments were performed 7 days after each injection. The antibodies were affinity-purified from serum using an antigen and eluted with $50 \mathrm{mM}$ glycine at $\mathrm{pH} 2.5$, neutralized with $1 \mathrm{M}$ Tris at $\mathrm{pH}$ 8 , and dialyzed into PBS buffer using the His-Brd4 ${ }^{\mathrm{BD} 2} \mathrm{L387 \textrm {A }}$ protein.

4.3.1. Competition Assay. Heterozygous BromoTag-Brd2 HEK293 cells were plated in six-well plates at a density of $5 \times 10^{5}$ cells per well in $2 \mathrm{~mL}$ DMEM. At the initiation of experiment, the cells were treated with either $3 \mu \mathrm{M}$ of MLN4924, $50 \mu \mathrm{M}$ of MG132, $10 \mu \mathrm{M}$ of $\mathrm{VH} 298,10 \mu \mathrm{M}$ of ET-JQ1-OMe, or 0.1\% DMSO. After $1 \mathrm{~h}$, $200 \mathrm{nM}$ of AGB1 (46) was added to the previously compoundtreated cells. After $3 \mathrm{~h}$, the cells were harvested for subsequent processing via western blot. Each treatment was performed in tandem to produce two technical repeats per condition. The six-well plates were incubated for $4 \mathrm{~h}$ at $37{ }^{\circ} \mathrm{C}$ and $5 \% \mathrm{CO}_{2}$ throughout the experiment.

4.3.2. Western Blotting. All cells were harvested on ice with RIPA lysis and extraction buffer (Thermo Fisher Scientific, 89901) supplemented with protease inhibitor cocktail (Merck, 11697498001) and Benzonase Nuclease (Sigma, E1014) before being stored at $-20{ }^{\circ} \mathrm{C}$ prior to use. Total protein quantity was determined using the BCA protein assay (\#23225, Pierce, Rockford, Illinois). The protein concentration was determined using the BCA assay (Thermo Fisher Scientific, 23225). The samples were then prepared and loaded onto NuPAGE $4-12 \%$ bis-tris Midi gels (Thermo Fisher Scientific, WG1403A), followed by the transfer of proteins onto nitrocellulose membranes (EMD Millipore). The membranes were blocked for $1 \mathrm{~h}$ prior to incubation with the primary antibodies using 5\% Milk TBST. The membranes were probed for Brd2 (Abcam, Ab139690, 1:1000), Brd3 (Abcam, Ab50818, 1:4000), Brd4 (Abcam, Ab128874, 1:1000), or our polyclonal $\mathrm{Brd} 4^{\mathrm{BD} 2 \mathrm{~L} 387 \mathrm{~A}}$ antibody. Following overnight incubation with the primary antibodies at $4{ }^{\circ} \mathrm{C}$, the membranes were incubated with secondary antibodies (anti-rabbit, Abcam AB216773, 1:5000 or anti-mouse, Abcam AB216774, 1:5000) and hFABTM rhodamine anti-tubulin antibody (Biorad, 12004165, 1:10,000) for $1 \mathrm{~h}$ and then imaged with a Bio-Rad imager (LI-COR Biosciences). All western blots were analyzed for band intensities using Image Lab from BioRad (LI-COR, Biosciences). The data extracted from these blots were then plotted and analyzed using Prism (v. 8.2.0, GraphPad).

4.3.3. Cell Viability Assay. MV-4-11, 22RV1, and HEK293 cells were all plated at a density of $2 \times 10^{4}$ cells per well of a 96-well whitebottom plate and left to grow overnight in $50 \mu \mathrm{L}$ of their respective medias, namely IMDM, RPM1-1640, and DMEM(Invitrogen, Carlsbad, CA, USA), supplemented with $10 \%$ (v/v) FBS (Thermo Fisher, Waltham, MA, USA) and $1 \%(\mathrm{v} / \mathrm{v})$ penicillin/streptomycin (pen/strep) (\#15140122, Thermo Fisher, Waltham, MA, USA) at 37 ${ }^{\circ} \mathrm{C}, 5 \% \mathrm{CO}_{2}$, and $95 \%$ humidity. The cells were then treated with 50 $\mu \mathrm{L}$ of media supplemented with $2 \times$ compound treatment, including DMSO, AGB1 (46), cis-AGB1 (52), MZ1, cis-MZ1, or staurosporine. Cells were then left to incubate at $37^{\circ} \mathrm{C}, 5 \% \mathrm{CO}_{2}$, and $95 \%$ humidity for 1 day (MV-4-11) or 2 days (22RV1 or HEK293) prior to undergoing spectrophotometric analysis. All cell lines were treated with compounds in duplicate (triplicate for DMSO controls) at a $1 \times$ concentration in $0.1 \%$ DMSO. The compounds were serially diluted to produce a 7-point, 10-fold titration. The cells were treated with 50:100 $\mu \mathrm{L}$ of compound for a final concentration of $10 \mu \mathrm{M}: 10 \mathrm{pM}$ in $0.1 \%$ DMSO. At the point of spectrometric analysis, cells were treated with $100 \mu \mathrm{L}$ of Promega CellTiter-Glo 2.0 Cell Viability Assay reagent. The plates were subjected to an orbital shaker for 2 min to encourage lysis and left for a further $5 \mathrm{~min}$ to reach peak luminescence. Luminescence was then recorded on a BMG Labtech PHERAstar luminescence plate reader with recommended settings. Data extracted from this analysis was analyzed with GraphPad Prism (v. 8.2.0, GraphPad) and normalized to the DMSO vehicle control. The $\mathrm{EC}_{50}$ values were derived from these plots.

4.3.4. Sample Processing, TMT Labeling, and Fractionation. CRISPR-modified BromoTag-Brd2 HEK293 cells $\left(5 \times 10^{6}\right)$ were seeded on a $100 \mathrm{~cm}$ plate $24 \mathrm{~h}$ before treatment. The cells were treated with either DMSO, $1 \mu \mathrm{M}$ AGB1, or $1 \mu \mathrm{M}$ cis-AGB1. After $2 \mathrm{~h}$ of treatment, the cells were washed twice with PBS. The cells were lysed in $150 \mu \mathrm{L}$ of $100 \mathrm{mM}$ TEAB and $5 \%(\mathrm{w} / \mathrm{v})$ sodium dodecyl sulfate. The lysate was sonicated for $10 \mathrm{~s}$ and then centrifuged at $15,000 \mathrm{~g}$ for $5 \mathrm{~min}$ with the supernatant collected post-centrifugation. The samples were then quantified using a micro-BCA protein assay kit (Thermo Fisher Scientific); $300 \mu \mathrm{g}$ of each sample was then reduced, alkylated, and then digested using the Strap mini protocol (protifi) as described by the manufacturer (protifi) with some modification. The samples were double-digested with trypsin (1:40) first overnight and then for another $6 \mathrm{~h}$ with the same ratio $(1: 40)$ in $50 \mathrm{mM}$ TEAB buffer. The peptides were quantified using a quantitative fluorometric peptide assay (Thermo Fisher Scientific). The samples (90 $\mu \mathrm{g}$ each) were labeled with a TMT 10-plex Isobaric Label Reagent set (Thermo Fisher Scientific) as per the manufacturer's instructions. After labeling, the samples were checked for labeling efficiency and then mixed, desalted, and dried in a speed-vac at $30{ }^{\circ} \mathrm{C}$. The samples were redissolved in $200 \mu \mathrm{L}$ of ammonium formate $(10 \mathrm{mM}, \mathrm{pH} 9.5)$, and peptides were fractionated using high-pH RP chromatography. A C18 column from Waters (XBridge peptide BEH, $130 \AA$ A $3.5 \mu \mathrm{m} 2.1 \times 150$ $\mathrm{mm}$, Waters, Ireland) with a guard column (XBridge, C18, $3.5 \mu \mathrm{m}$, $2.1 \times 10 \mathrm{~mm}$, Waters) was used on an Ultimate 3000 HPLC (Thermo Scientific). Buffers A and B used for fractionation consist, respectively, of (A) $10 \mathrm{mM}$ ammonium formate in Milli- $\mathrm{Q}$ water $\mathrm{pH} 9.5$ and (B) $10 \mathrm{mM}$ ammonium formate, $\mathrm{pH} 9.5$, in $90 \%$ acetonitrile. Fractions were collected using a WPS-3000FC auto-sampler (Thermo Scientific) at $1 \mathrm{~min}$ intervals. The column and guard column were equilibrated with $2 \%$ buffer B for $20 \mathrm{~min}$ at a constant flow rate of 0.2 $\mathrm{mL} / \mathrm{min}$. TMT-labeled peptides $(100 \mu \mathrm{L})$ were injected onto the column, and the separation gradient was started $1 \mathrm{~min}$ after the sample was loaded onto the column. The peptides were eluted from the column with a gradient of $2 \%$ buffer B to $20 \%$ buffer B in 6 min, then from $20 \%$ buffer B to $45 \%$ buffer B in $51 \mathrm{~min}$, and finally from $45 \%$ buffer B to $100 \%$ buffer B within 1 min. The column was washed for $15 \mathrm{~min}$ in $100 \%$ buffer B. The fraction collection started $1 \mathrm{~min}$ after injection and stopped after $80 \mathrm{~min}$ (total 80 fractions, $200 \mu \mathrm{L}$ each). To acidify the eluting peptides, $30 \mu \mathrm{L}$ of $10 \%$ formic acid was added to each of the 80 fractionation vials. The total number of fractions concatenated was set to 20 .

4.3.5. LC-MS Analysis. Analysis of peptides was performed on a Q-exactive-HF (Thermo Scientific) mass spectrometer coupled with a Dionex Ultimate 3000 RS (Thermo Scientific). The LC buffers are as follows: buffer A [0.1\% formic acid in Milli-Q water (v/v)] and buffer B ( $80 \%$ acetonitrile and $0.1 \%$ formic acid in Milli-Q water $(\mathrm{v} / \mathrm{v})]$. Aliquots of $7 \mu \mathrm{L}$ of each sample were loaded at $10 \mu \mathrm{L} / \mathrm{min}$ onto a trap column $(100 \mu \mathrm{m} \times 2 \mathrm{~cm}$, PepMap nanoViper C18 column, $5 \mu \mathrm{m}, 100$ $\AA$, Thermo Scientific) equilibrated in $0.1 \%$ TFA. The trap column was washed for $3 \mathrm{~min}$ at the same flow rate with $0.1 \%$ TFA and then switched in-line with a Thermo Scientific, resolving a C18 column (75 $\mu \mathrm{m} \times 50 \mathrm{~cm}$, PepMap RSLC C18 column, $2 \mu \mathrm{m}, 100 \AA$ ). The peptides were eluted from the column at a constant flow rate of 300 $\mathrm{nl} / \mathrm{min}$ with a linear gradient from $5 \%$ buffer B (for fractions 1-10, $7 \%$ for fractions $11-20$ ) to $35 \%$ buffer B in $125 \mathrm{~min}$ and then from $35 \%$ buffer B to $98 \%$ buffer B in 2 min. The column was then washed with $98 \%$ buffer B for $20 \mathrm{~min}$ and re-equilibrated in $5 \%$ or $7 \%$ buffer B for $17 \mathrm{~min}$. The column was kept all the time at a constant temperature of $50{ }^{\circ} \mathrm{C}$. Q-exactive $\mathrm{HF}$ was operated in the datadependent positive ionization mode. The source voltage was set to $2.25 \mathrm{kV}$, and the capillary temperature was $250{ }^{\circ} \mathrm{C}$. A scan cycle comprised MS1 scan $[\mathrm{m} / z$ range from 335 to 1600 , with a maximum ion injection time of $50 \mathrm{~ms}$, a resolution of 120,000, and an automatic gain control (AGC) value of $3 \times 10^{6}$ ], followed by 15 sequentially dependent MS2 scans (resolution 60,000) of the most intense ions fulfilling the predefined selection criteria (AGC $1 \times 10^{5}$ ), maximum ion injection time $200 \mathrm{~ms}$, isolation window of $0.7 \mathrm{~m} / z$, fixed first mass of $100 \mathrm{~m} / z$, spectrum data type: centroid, intensity threshold 5 $\times 10^{4}$, exclusion of unassigned, singly and $>6$ charged precursors, peptide match preferred, exclude isotopes on, and dynamic exclusion time $45 \mathrm{~s}$ ). The HCD collision energy was set to $32 \%$ of the 
normalized collision energy. The mass accuracy is checked before the initiation of sample analysis.

4.3.6. Peptide and Protein Identification. The raw data files for all fractions were merged and searched against the Uniprot-humancanonical database by MaxQuant software v.1.6.0.16 for protein identification and TMT reporter ion quantitation. The following MaxQuant parameters were used: the enzyme used is trypsin/P; the maximum number of missed cleavages is 2 ; the precursor mass tolerance is $10 \mathrm{ppm}$; the fragment mass tolerance is $20 \mathrm{ppm}$; variable modifications of oxidation (M), acetyl (N-term), deamidation (NQ), and Gln $\rightarrow$ pyro-Glu (Q N-term); and fixed modifications of carbamidomethyl (C). The data were filtered by applying a $1 \%$ false discovery rate, followed by exclusion of proteins with fewer than two unique peptides. The quantified proteins were filtered if the absolute fold change difference between the three DMSO replicates was $\geq 1.5$.

4.3.7. Protein Expression and Purification. VCB was expressed and purified as described previously. ${ }^{15}$ Briefly, the N-terminally $\mathrm{His}_{6-}$ tagged VHL (54-213), elongin C (17-112), and elongin B (1-104) were co-expressed in E. coli, and the complex was isolated using Niaffinity chromatography using TEV protease to remove His6 Tag. The complex was further purified by anion exchange, followed by gel filtration chromatography. Brd4-BD2 $2^{\mathrm{L} 387 \mathrm{~A}}$ was expressed and purified as described previously. ${ }^{15,18}$ Briefly, the $\mathrm{N}$-terminally $\mathrm{His}_{6}$-tagged $\mathrm{Brd} 4-\mathrm{BD} 2^{\mathrm{L} 387 \mathrm{~A}}(333-460)$ was expressed in E. coli and isolated by Niaffinity chromatography using TEV protease to remove His6 Tag, followed by gel filtration chromatography.

4.3.8. FP Binding Assay. FP competitive binding assays were performed as described previously, ${ }^{17,41}$ with all measurements taken using a PHERAstar FS (BMG LABTECH) with fluorescence excitation and emission wavelengths $(\lambda)$ of 485 and $520 \mathrm{~nm}$, respectively. Assays were run in triplicate using 384-well plates (Corning 3820), with each well solution containing $15 \mathrm{nM}$ VCB protein, $10 \mathrm{nM}$ 5,6-carboxyfluorescein (FAM)-labeled HIF-1 $\alpha$ peptide (FAM-DEALAHypYIPMDDDFQLRSF, "JC9"), and decreasing concentrations of PROTACs (14-point, 2-fold serial dilution starting from $20 \mu \mathrm{M}$ PROTAC) or PROTACs/bromodomain (14point, 2-fold serial dilution starting from $20 \mu \mathrm{M}$ PROTAC: $50 \mu \mathrm{M}$ bromodomain added into buffer containing $10 \mu \mathrm{M}$ bromodomain). All components were dissolved from stock solutions using $100 \mathrm{mM}$ bis-tris propane, $100 \mathrm{mM} \mathrm{NaCl}, 1 \mathrm{mM} \mathrm{DTT}, \mathrm{pH} 7.0$, to yield a final assay volume of $15 \mu \mathrm{L}$. DMSO was added as appropriate to ensure a final concentration of $2 \% \mathrm{v} / \mathrm{v}$. Control wells containing VCB and JC9 with no compound (zero displacement), or JC9, in the absence of protein (maximum displacement) were also included to allow for normalization. Percentage displacement values were obtained by normalization of controls and were plotted against $\log$ [compound]. The $\mathrm{IC}_{50}$ values were determined for each titration using nonlinear regression analysis with Prism (v. 9.1.0, GraphPad). The $K_{\mathrm{i}}$ values were back-calculated from the $K_{\mathrm{d}}$ for JC9 $(\sim 1.5-2.5 \mathrm{nM}$, determined from direct binding) and fitted $\mathrm{IC}_{50}$ values, as described previously. ${ }^{41,42}$ Cooperativity values $(\alpha)$ for each PROTAC were calculated using the ratio: $\alpha=$ binary $K_{\mathrm{d}}$ (-bromodomain)/ternary $K_{\mathrm{d}}$ (+bromodomain).

4.3.9. Plasma Stability. Plasma stability studies were outsourced and undertaken by Shanghai ChemPartner Co., Ltd. Buffer preparation: a solution of $0.05 \mathrm{M}$ sodium phosphate and $0.07 \mathrm{M}$ $\mathrm{NaCl}$ buffer at $\mathrm{pH} 7.4$ was made by dissolving $14.505 \mathrm{~g} / \mathrm{L}$ of $\mathrm{Na}_{2} \mathrm{HPO}_{4} \cdot 12 \mathrm{H}_{2} \mathrm{O}, 1.483 \mathrm{~g} / \mathrm{L}$ of $\mathrm{NaH}_{2} \mathrm{PO}_{4} \cdot 2 \mathrm{H}_{2} \mathrm{O}$, and $4.095 \mathrm{~g} / \mathrm{L}$ of $\mathrm{NaCl}$ in deionized water, and the $\mathrm{pH}$ was adjusted with phosphoric acid. Plasma preparation: frozen mouse plasma was thawed by placing at $37^{\circ} \mathrm{C}$ quickly. The thawed plasma was centrifuged at $3000 \mathrm{rpm}$ for $8 \mathrm{~min}$ to remove clots, and the supernatant was pooled to be used as the plasma in the experiment. The plasma ( $\mathrm{pH}$ 7.4-8.0) was stored on ice until used. AGB1 (46) and reference compound procaine were prepared as a spiking solution $(0.02 \mathrm{mM})$ compound in $0.05 \mathrm{mM}$ sodium phosphate buffer with $0.5 \%$ BSA (bovine serum albumin) and $4 \% \mathrm{v} / \mathrm{v} / \mathrm{DMSO}$. Plasma and spiking solutions were prewarmed at 37 ${ }^{\circ} \mathrm{C}$ for $5 \mathrm{~min}$, and then $10 \mu \mathrm{L}$ of prewarmed spiking solution $\mathrm{B}$ was added into the wells designated for all the time points $(5,15,30,45$, and $60 \mathrm{~min}$ ). For $0 \mathrm{~min}, 400 \mu \mathrm{L}$ of acetonitrile-containing internal standards (imipramine, glipizide) was added to the wells of a $0 \mathrm{~min}$ plate, and then $90 \mu \mathrm{L}$ of plasma was added. For the time points $(0,5$, $15,30,45$, and $60 \mathrm{~min}$ ), $90 \mu \mathrm{L}$ of prewarmed plasma was added at the initial stage. At 5, 15, 30, 45, and $60 \mathrm{~min}, 400 \mu \mathrm{L}$ of acetonitrile containing the internal standard (imipramine, glipizide) was added to the wells of the corresponding plates to stop the reaction. After quenching, the plates were shaken at the vibrator (IKA, MTS 2/4) for $10 \mathrm{~min}(600 \mathrm{rpm} / \mathrm{min})$ and then centrifuged at $5594 \mathrm{~g}$ for $15 \mathrm{~min}$ (Thermo Multifuge $\times 3 \mathrm{R})$. The supernatant $(50 \mu \mathrm{L})$ from each well of the centrifuged plate was transferred into a new 96-well sample plate containing $50 \mu \mathrm{L}$ of ultra-pure water (Millipore, ZMQS50F01) for LC/MS analysis [LC-MS/MS-49 (API6500+), UPLC-MSMS-32 (Triple Quad 6500+)]. Data was analyzed with Microsoft Excel.

4.3.10. In Vivo PK Profiling. PK profiling was outsourced and undertaken by Shanghai ChemPartner Co., Ltd. All animal experiments performed were conducted in compliance with the Institutional Animal Care and Use Committee (IACUC) and the Office of Laboratory Animal Welfare (OLAW) guidelines. Six- to eight-weekold C57BL/6 male mice purchased from Jihui Laboratory Animal Co. LTD were used in the study. AGB1 (46) was formulated in 5\% DMSO $+5 \%$ Solutol HS $15+90 \%$ saline at $1 \mathrm{mg} / \mathrm{mL}$. For IV injections, $5 \mathrm{mg} / \mathrm{kg}$ of AGB1 (46) was administered into the tail vein of nine mice. For SC injections, $5 \mathrm{mg} / \mathrm{kg}$ of AGB1 (46) was administered via SC injection in nine mice. The animals were restrained manually at the designated time points $(0.083,0.25,0.5,1$, 2 , 4, and $8 \mathrm{~h}$ ); approximately, $110 \mu \mathrm{L}$ of blood sample was collected via facial vein into $\mathrm{K}_{2}$ EDTA tubes. Three mice per time point were used, resulting in a total of 18 mice. The blood sample was put on ice and centrifuged at $2000 \mathrm{~g}$ for $5 \mathrm{~min}$ to obtain the plasma sample within $15 \mathrm{~min}$. The plasma samples were stored at approximately $-70{ }^{\circ} \mathrm{C}$ until analysis. A $30 \mu \mathrm{L}$ aliquot of plasma was added with $200 \mu \mathrm{L}$ of internal standard (diclofenac, $40 \mathrm{ng} / \mathrm{mL}$ ) in $1 \%$ formic acid in $\mathrm{MeCN}$. The mixture was then vortexed for $1 \mathrm{~min}$ and then centrifuged for 10 $\min$ at $5800 \mathrm{rpm}$. The supernatant $(100 \mu \mathrm{L})$ was transferred to a new plate. The solvent $(0.5 \mu \mathrm{L})$ was injected to LC-MS/MS. LC-MS/ MS instrument used: SCIEX LC-MS/MS-45 (Triple Quad 6500+). Data was analyzed by WinNonLin and Microsoft Excel.

\section{ASSOCIATED CONTENT}

\section{SI Supporting Information}

The Supporting Information is available free of charge at https://pubs.acs.org/doi/10.1021/acs.jmedchem.1c01532.

DNA sequences of BromoTag degron components; junction PCR; genotyping of the span of eGFP-P2ABromoTag in the heterozygous BromoTag-Brd2 Hek293 cell line; protein degradation profiles of PROTACs 1825 for Brd4 long, Brd4 short, Brd3, Brd2, and $\mathrm{Brd} 4^{\mathrm{BD} 2} \mathrm{~L} 387 \mathrm{~A}$; protein degradation profile of AGB1 (46), AGB2 (47), and AGB3 (48) for Brd4 ${ }^{\mathrm{BD} 2 \mathrm{~L} 387 \mathrm{~A}}$ and $\mathrm{Brd} 2$; original uncropped western blot images; HPLC-HRMS traces for compounds $46-48$ and 52; and NMR spectra for compounds $\mathbf{4 6 - 4 8}$ and 52 (PDF) Molecular formula strings with relevant binding and degradation assay data (CSV)

\section{AUTHOR INFORMATION}

\section{Corresponding Author}

Alessio Ciulli - Division of Biological Chemistry and Drug Discovery, School of Life Sciences, University of Dundee, Dundee DD1 5EH Scotland, U.K.; (i) orcid.org/0000-00028654-1670; Phone: +44(0)1382386230; Email: a.ciulli@ dundee.ac.uk

\section{Authors}

Adam G. Bond - Division of Biological Chemistry and Drug Discovery, School of Life Sciences, University of Dundee, 
Dundee DD1 5EH Scotland, U.K.; 이이.org/0000-00021271-1032

Conner Craigon - Division of Biological Chemistry and Drug Discovery, School of Life Sciences, University of Dundee, Dundee DD1 5EH Scotland, U.K.

Kwok-Ho Chan - Division of Biological Chemistry and Drug Discovery, School of Life Sciences, University of Dundee, Dundee DD1 5EH Scotland, U.K.; Present Address: GSK, Gunnels Wood Rd, Stevenage, SG1 2NY, U.K; (1) orcid.org/0000-0002-6693-2682

Andrea Testa - Division of Biological Chemistry and Drug Discovery, School of Life Sciences, University of Dundee, Dundee DD1 5EH Scotland, U.K.; Present Address: Amphista Therapeutics Ltd., BioCity, Bo'Ness Rd, Newhouse, Chapelhall, Motherwell, ML1 5UH, U.K. Athanasios Karapetsas - MRC Protein Phosphorylation and Ubiquitylation Unit, Sir James Black Centre, School of Life Sciences, University of Dundee, Dundee DD1 5EH Scotland, U.K.; Present Address: AstraZeneca, Hodgkin Building B900, Chesterford Research Park, Little Chesterford, Cambridge, CB10 1XL, U.K.

Rotimi Fasimoye - MRC Protein Phosphorylation and Ubiquitylation Unit, Sir James Black Centre, School of Life Sciences, University of Dundee, Dundee DD1 5EH Scotland, U.K.; (1) orcid.org/0000-0001-8057-0879

Thomas Macartney - MRC Protein Phosphorylation and Ubiquitylation Unit, Sir James Black Centre, School of Life Sciences, University of Dundee, Dundee DD1 5EH Scotland, U.K.; (1) orcid.org/0000-0002-6745-183X

J. Julian Blow - Centre for Gene Regulation \& Expression, School of Life Sciences, University of Dundee, Dundee DD1 5EH Scotland, U.K.; (1) orcid.org/0000-0002-9524-5849

Dario R. Alessi - MRC Protein Phosphorylation and Ubiquitylation Unit, Sir James Black Centre, School of Life Sciences, University of Dundee, Dundee DD1 5EH Scotland, U.K.; (1) orcid.org/0000-0002-2140-9185

Complete contact information is available at: https://pubs.acs.org/10.1021/acs.jmedchem.1c01532

\section{Author Contributions}

IIA.G.B. and C.C. are co-first authors. The manuscript was written through contributions of all authors and edited by all. A.G.B. and C.C. contributed equally.

\section{Notes}

The authors declare the following competing financial interest(s): The University of Dundee has filed a patent application (GB2113656.9) related to the BromoTag technology. The A.C. laboratory receives or has received sponsored research support from Almirall, Amphista Therapeutics, Boehringer Ingelheim, Eisai Co., Nurix, and Ono Pharmaceuticals. A.C. is scientific founder, shareholder and consultant of Amphista Therapeutics, a company that is developing targeted protein degradation therapeutic platforms.

\section{ACKNOWLEDGMENTS}

This project has received funding by the European Research Council (ERC, Starting Grant ERC-2012-StG-311460 DrugE3CRLs to A.C.); the Innovative Medicines Initiative 2 (IMI2) Joint Undertaking under grant agreement no. 875510 (EUbOPEN project to A.C.) from the European Union's Horizon 2020 research and innovation programme; the Medical Research Council (MRC, MC UU 12016/2 to
D.R.A.); and a Wellcome Trust Senior Investigator Award (WT096598MA to J.J.B.). A.G.B. is funded by a $\mathrm{PhD}$ studentship from the Medical Research Scotland (MRS) (1170-2017). C.C. is funded by a $\mathrm{PhD}$ studentship from the UK Medical Research Council (MRC) under the doctoral training programme in Quantitative and Inter-disciplinary approaches to biomedical science (QI Biomed) (MR/ N0123735/1). Biophysics and drug discovery activities at Dundee were supported by Welcome Trust strategic awards $100476 / \mathrm{Z} / 12 / \mathrm{Z}$ and $094090 / \mathrm{Z} / 10 / \mathrm{Z}$, respectively. We would like to thank Michael Zengerle for the synthesis of MZP-15; Satomi Imaide for assistance with chemistry; Nicole Ong and Christa Baker for assistance in the production of western blots; Andrew Runcie and Sarath Ramachandran for advice regarding experimental design; Douglas Lamond and Abdel Atrih from the fingerprint proteomics group at the University of Dundee for their help in the preparation and running of TMT mass spectrometry experiments; and Bixi Guan, Study Director DMPK Group \& Expl Tox Department at Shanghai ChemPartner Co., Ltd, for advice with and performing in vitro plasma stability and in vivo PK profiling of AGB1.

\section{ABBREVIATIONS}

AID, auxin-inducible degron; B\&H-PROTAC, bump-andhole-proteolysis targeting chimera; BET, bromo and extra terminal; Brd2/3/4, bromodomain containing protein 2/3/4; COMU, (1-cyano-2-ethoxy-2-oxoethylidenaminooxy)dimethylamino-morpholino-carbenium hexafluorophosphate; CRBN, carillon; CRISPR, clustered regularly interspaced short palindromic repeats; CRL2, cullin ring ligase 2; DIPEA, diisopropylethylamine; DMAP, 4-(dimethylamino)pyridine; EDC $\cdot \mathrm{HCl}, \mathrm{N}$-(3-dimethylaminopropyl)- $\mathrm{N}^{\prime}$-ethylcarbodiimide hydrochloride; FACS, fluorescence-activated cell sorting; FP, fluorescence polarization; HATU, 1-[bis(dimethylamino) methylene]-1H-1,2,3-triazolo[4,5-b]pyridinium 3-oxid hexafluorophosphate; HOAt, 1-hydroxy-7azabenzotriazole; KHMDS, potassium hexamethyldisilazane; LHMDS, lithium hexamethyldisilazane; PROTACs, proteolysis targeting chimeras; TBAF, tetrabutylammonium fluoride; TIR, transport inhibitor response 1; VCB, VHL-elongin C-elongin B; VHL, von Hippel-Lindau

\section{REFERENCES}

(1) Bond, M. J.; Crews, C. M. Proteolysis targeting chimeras (PROTACs) come of age: entering the third decade of targeted protein degradation. RSC Chem. Biol. 2021, 2, 725-742.

(2) Maniaci, C.; Ciulli, A. Bifunctional chemical probes inducing protein-protein interactions. Curr. Opin. Chem. Biol. 2019, 52, 145156.

(3) Zou, Y.; Ma, D.; Wang, Y. The PROTAC technology in drug development. Cell Biochem. Funct. 2019, 37, 21-30.

(4) An, S.; Fu, L. Small-molecule PROTACs: an emerging and promising approach for the development of targeted therapy drugs. EBioMedicine 2018, 36, 553-562.

(5) Oprea, T. I.; Bologa, C. G.; Brunak, S.; Campbell, A.; Gan, G. N.; Gaulton, A.; Gomez, S. M.; Guha, R.; Hersey, A.; Holmes, J.; Jadhav, A.; Jensen, L. J.; Johnson, G. L.; Karlson, A.; Leach, A. R.; Ma'ayan, A.; Malovannaya, A.; Mani, S.; Mathias, S. L.; McManus, M. T.; Meehan, T. F.; von Mering, C.; Muthas, D.; Nguyen, D.-T.; Overington, J. P.; Papadatos, G.; Qin, J.; Reich, C.; Roth, B. L.; Schürer, S. C.; Simeonov, A.; Sklar, L. A.; Southall, N.; Tomita, S.; Tudose, I.; Ursu, O.; Vidović, D.; Waller, A.; Westergaard, D.; Yang, J. J.; Zahoránszky-Köhalmi, G. Unexplored therapeutic opportunities in the human genome. Nat. Rev. Drug Discovery 2018, 17, 317-332. 
(6) Natsume, T.; Kiyomitsu, T.; Saga, Y.; Kanemaki, M. T. Rapid protein depletion in human cells by auxin-inducible degron tagging with short homology donors. Cell Rep. 2016, 15, 210-218.

(7) Torii, K. U.; Hagihara, S.; Uchida, N.; Takahashi, K. Harnessing synthetic chemistry to probe and hijack auxin signaling. New Phytol. 2018, 220, 417-424.

(8) Yesbolatova, A.; Saito, Y.; Kitamoto, N.; Makino-Itou, H.; Ajima, R.; Nakano, R.; Nakaoka, H.; Fukui, K.; Gamo, K.; Tominari, Y.; Takeuchi, H.; Saga, Y.; Hayashi, K.-i.; Kanemaki, M. T. The auxininducible degron 2 technology provides sharp degradation control in yeast, mammalian cells, and mice. Nat. Commun. 2020, 11, 5701.

(9) Buckley, D. L.; Raina, K.; Darricarrerre, N.; Hines, J.; Gustafson, J.; Smith, I.; Miah, A.; Harling, J.; Crews, C. HaloPROTACS: Use of small molecule PROTACs to induce degradation of HaloTag fusion proteins. ACS Chem. Biol. 2015, 10, 1031-1837.

(10) Tovell, H.; Testa, A.; Maniaci, C.; Zhou, H.; Prescott, A. R.; Macartney, T.; Ciulli, A.; Alessi, D. R. Rapid and reversible knockdown of endogenously tagged endosomal proteins via an optimized HaloPROTAC degrader. ACS Chem. Biol. 2019, 14, 882892.

(11) Nabet, B.; Roberts, J. M.; Buckley, D. L.; Paulk, J.; Dastjerdi, S.; Yang, A.; Leggett, A. L.; Erb, M. A.; Lawlor, M. A.; Souza, A.; Scott, T. G.; Vittori, S.; Perry, J. A.; Qi, J.; Winter, G. E.; Wong, K.-K.; Gray, N. S.; Bradner, J. E. The dTAG system for immediate and target-specific protein degradation. Nat. Chem. Biol. 2018, 14, 431-441.

(12) Nabet, B.; Ferguson, F. M.; Seong, B. K. A.; Kuljanin, M.; Leggett, A. L.; Mohardt, M. L.; Robichaud, A.; Conway, A. S.; Buckley, D. L.; Mancias, J. D.; Bradner, J. E.; Stegmaier, K.; Gray, N. S. Rapid and direct control of target protein levels with VHLrecruiting dTAG molecules. Nat. Commun. 2020, 11, 4687.

(13) Ishoey, M.; Chorn, S.; Singh, N.; Jaeger, M. G.; Brand, M.; Paulk, J.; Bauer, S.; Erb, M. A.; Parapatics, K.; Müller, A. C.; Bennett, K. L.; Ecker, G. F.; Bradner, J. E.; Winter, G. E. Translation termination factor GSPT1 is a phenotypically relevant off-target of heterobifunctional phthalimide degraders. ACS Chem. Biol. 2018, 13, $553-560$.

(14) Zengerle, M.; Chan, K.-H.; Ciulli, A. Selective small molecule induced degradation of the BET bromodomain protein BRD4. ACS Chem. Biol. 2015, 10, 1770-1777.

(15) Gadd, M. S.; Testa, A.; Lucas, X.; Chan, K.-H.; Chen, W.; Lamont, D. J.; Zengerle, M.; Ciulli, A. Structural basis of PROTAC cooperative recognition for selective protein degradation. Nat. Chem. Biol. 2017, 13, 514-521.

(16) Chan, K.-H.; Zengerle, M.; Testa, A.; Ciulli, A. Impact of target warhead and linkage vector on inducing protein degradation: comparison of bromodomain and extra-terminal (BET) degraders derived from triazolodiazepine (JQ1) and tetrahydroquinoline (IBET726) BET inhibitor scaffolds. J. Med. Chem. 2018, 61, 504-513.

(17) Roy, M. J.; Winkler, S.; Hughes, S. J.; Whitworth, C.; Galant, M.; Farnaby, W.; Rumpel, K.; Ciulli, A. SPR-Measured dissociation kinetics of PROTAC ternary complexes influence target degradation rate. ACS Chem. Biol. 2019, 14, 361-368.

(18) Baud, M. G. J.; Lin-Shiao, E.; Cardote, T.; Tallant, C.; Pschibul, A.; Chan, K.-H.; Zengerle, M.; Garcia, J. R.; Kwan, T. T. L.; Ferguson, F. M.; Ciulli, A. A bump-and-hole approach to engineer controlled selectivity of BET bromodomain chemical probes. Science 2014, 346, 638-641.

(19) Baud, M. G. J.; Lin-Shiao, E.; Zengerle, M.; Tallant, C.; Ciulli, A. New synthetic routes to triazolo-benzodiazepine analogues: expanding the scope of the bump-and-hole approach for selective bromo and extra-terminal (BET) bromodomain inhibition. J. Med. Chem. 2016, 59, 1492-1500.

(20) Runcie, A. C.; Zengerle, M.; Chan, K.-H.; Testa, A.; van Beurden, L.; Baud, M. G. J.; Epemolu, O.; Ellis, L. C. J.; Read, K. D.; Coulthard, V.; Brien, A.; Ciulli, A. Optimization of a "bump-and-hole" approach to allele-selective BET bromodomain inhibition. Chem. Sci. 2018, 9, 2452-2468.
(21) Bond, A. G.; Testa, A.; Ciulli, A. Stereoselective synthesis of allele-specific BET inhibitors. Org. Biomol. Chem. 2020, 18, 75337539.

(22) Testa, A.; Lucas, X.; Castro, G. V.; Chan, K.-H.; Wright, J. E.; Runcie, A. C.; Gadd, M. S.; Harrison, W. T. A.; Ko, E.-J.; Fletcher, D.; Ciulli, A. 3-Fluoro-4-hydroxyprolines: Synthesis, conformational analysis, and stereoselective recognition by the VHL E3 ubiquitin ligase for targeted protein degradation. J. Am. Chem. Soc. 2018, 140, 9299-9313.

(23) Riching, K. M.; Mahan, S.; Corona, C. R.; McDougall, M.; Vasta, J. D.; Robers, M. B.; Urh, M.; Daniels, D. L. Quantitative livecell kinetic degradation and mechanistic profiling of PROTAC mode of action. ACS Chem. Biol. 2018, 13, 2758-2770.

(24) Filippakopoulos, P.; Knapp, S. Targeting bromodomains: epigenetic readers of lysine acetylation. Nat. Rev. Drug Discovery 2014, $13,337-356$

(25) Raina, K.; Lu, J.; Qian, Y.; Altieri, M.; Gordon, D.; Rossi, A. M. K.; Wang, J.; Chen, X.; Dong, H.; Siu, K.; Winkler, J. D.; Crew, A. P.; Crews, C. M.; Coleman, K. G. PROTAC-induced BET protein degradation as a therapy for castration-resistant prostate cancer. Proc. Natl. Acad. Sci. U.S.A. 2016, 113, 7124-7129.

(26) Galdeano, C.; Gadd, M. S.; Soares, P.; Scaffidi, S.; Van Molle, I.; Birced, I.; Hewitt, S.; Dias, D. M.; Ciulli, A. Structure-guided design and optimization of small molecules targeting the proteinprotein interaction between the von Hippel-Lindau (VHL) E3 ubiquitin ligase and the hypoxia inducible factor (HIF) alpha subunit with in vitro nanomolar affinities. J. Med. Chem. 2014, 57, 86578663.

(27) Hu, J.; Hu, B.; Wang, M.; Xu, F.; Miao, B.; Yang, C.-Y.; Wang, M.; Liu, Z.; Hayes, D. F.; Chinnaswamy, K.; Delproposto, J.; Stuckey, J.; Wang, S. Discovery of ERD-308 as a highly potent proteolysis targeting chimera (PROTAC) degrader of estrogen receptor (ER). J. Med. Chem. 2019, 62, 1420-1442.

(28) Filippakopoulos, P.; Qi, J.; Picaud, S.; Shen, Y.; Smith, W. B.; Fedorov, O.; Morse, E. M.; Keates, T.; Hickman, T. T.; Felletar, I.; Philpott, M.; Munro, S.; McKeown, M. R.; Wang, Y.; Christie, A. L.; West, N.; Cameron, M. J.; Schwartz, B.; Heightman, T. D.; La Thangue, N.; French, C. A.; Wiest, O.; Kung, A. L.; Knapp, S.; Bradner, J. E. Selective inhibition of BET bromodomains. Nature 2010, 468, 1067-1073.

(29) Douglass, E. F.; Miller, C. J.; Sparer, G.; Shapiro, H.; Spiegel, D. A. A comprehensive mathematical model for three-body binding equilibria. J. Am. Chem. Soc. 2013, 135, 6092-6099.

(30) Klein, V.; Bond, A.; Craigon, C.; Lokey, R. S.; Ciulli, A. Amideto-ester substitution as a strategy for optimizing PROTAC permeability and cellular activity. 2021, ChemRxiv. 10.33774/ chemrxiv-2021-47tqn

(31) Zoppi, V.; Hughes, S. J.; Maniaci, C.; Testa, A.; Gmaschitz, T.; Wieshofer, C.; Koegl, M.; Riching, K. M.; Daniels, D. L.; Spallarossa, A.; Ciulli, A. Iterative design and optimization of initially inactive proteolysis targeting chimeras (PROTACs) identify VZ185 as a potent, fast, and selective von Hippel-Lindau (VHL) based dual degrader probe of BRD9 and BRD7. J. Med. Chem. 2019, 62, 699726 .

(32) Farnaby, W.; Koegl, M.; Roy, M. J.; Whitworth, C.; Diers, E.; Trainor, N.; Zollman, D.; Steurer, S.; Karolyi-Oezguer, J.; Riedmueller, C.; Gmaschitz, T.; Wachter, J.; Dank, C.; Galant, M.; Sharps, B.; Rumpel, K.; Traxler, E.; Gerstberger, T.; Schnitzer, R.; Petermann, O.; Greb, P.; Weinstabl, H.; Bader, G.; Zoephel, A.; Weiss-Puxbaum, A.; Ehrenhöfer-Wölfer, K.; Wöhrle, S.; Boehmelt, G.; Rinnenthal, J.; Arnhof, H.; Wiechens, N.; Wu, M.-Y.; Owen-Hughes, T.; Ettmayer, P.; Pearson, M.; McConnell, D. B.; Ciulli, A. BAF complex vulnerabilities in cancer demonstrated via structure-based PROTAC design. Nat. Chem. Biol. 2019, 15, 672-680.

(33) Testa, A.; Hughes, S. J.; Lucas, X.; Wright, J. E.; Ciulli, A. Structure-Based Design of a Macrocyclic PROTAC. Angew. Chem., Int. Ed. 2020, 59, 1727-1734.

(34) Imaide, S.; Riching, K. M.; Vetma, V.; Whitworth, C.; Hughes, S. J.; Trainor, N.; Mahan, S. D.; Murphy, N.; Chan, K.-H.; Testa, A.; 
Maniaci, C.; Urh, M.; Daniels, D. L.; Ciulli, A., Trivalent PROTACs enhance protein degradation through cooperativity and avidity. 2020, ChemRxiv, 10.26434/chemrxiv.13218695

(35) Soucy, T. A.; Smith, P. G.; Rolfe, M. Targeting NEDD8activated cullin-RING ligases for the treatment of cancer. Clin. Cancer Res. 2009, 15, 3912-3916.

(36) Frost, J.; Galdeano, C.; Soares, P.; Gadd, M. S.; Grzes, K. M.; Ellis, L.; Epemolu, O.; Shimamura, S.; Bantscheff, M.; Grandi, P.; Read, K. D.; Cantrell, D. A.; Rocha, S.; Ciulli, A. Potent and selective chemical probe of hypoxic signalling downstream of HIF- $\alpha$ hydroxylation via VHL inhibition. Nat. Commun. 2016, 7, 13312.

(37) Rock, K. L.; Gramm, C.; Rothstein, L.; Clark, K.; Stein, R.; Dick, L.; Hwang, D.; Goldberg, A. L. Inhibitors of the proteasome block the degradation of most cell proteins and the generation of peptides presented on MHC class I molecules. Cell 1994, 78, 761771.

(38) Boehringer Ingelheim-opnMe. https://opnme.com/molecules/ bet-mz-1 (accessed Aug 24, 2021).

(39) Nowak, R. P.; Xiong, Y.; Kirmani, N.; Kalabathula, J.; Donovan, K. A.; Eleuteri, N. A.; Yuan, J. C.; Fischer, E. S. Structure-guided design of a "bump-and-hole" bromodomain-based degradation tag. J. Med. Chem. 2021, 64, 11637-11650.

(40) Chung, C.-w.; Coste, H.; White, J. H.; Mirguet, O.; Wilde, J.; Gosmini, R. L.; Delves, C.; Magny, S. M.; Woodward, R.; Hughes, S. A.; Boursier, E. V.; Flynn, H.; Bouillot, A. M.; Bamborough, P.; Brusq, J.-M. G.; Gellibert, F. J.; Jones, E. J.; Riou, A. M.; Homes, P.; Martin, S. L.; Uings, I. J.; Toum, J.; Clément, C. A.; Boullay, A.-B.; Grimley, R. L.; Blandel, F. M.; Prinjha, R. K.; Lee, K.; Kirilovsky, J.; Nicodeme, E. Discovery and characterization of small molecule inhibitors of the BET family bromodomains. J. Med. Chem. 2011, 54, 3827-3838.

(41) Van Molle, I.; Thomann, A.; Buckley, D. L.; So, E. C.; Lang, S.; Crews, C. M.; Ciulli, A. Dissecting fragment-based lead discovery at the von Hippel-Lindau protein:hypoxia inducible factor $1 \alpha$ proteinprotein interface. Chem. Biol. 2012, 19, 1300-1312.

(42) Soares, P.; Gadd, M. S.; Frost, J.; Galdeano, C.; Ellis, L.; Epemolu, O.; Rocha, S.; Read, K. D.; Ciulli, A. Group-based optimization of potent and cell-Active inhibitors of the von Hippel-Lindau (VHL) E3 ubiquitin ligase: structure-activity relationships leading to the chemical probe $(2 S, 4 \mathrm{R})-1-((\mathrm{S})-2-(1-$ cyanocyclopropanecarboxamido)-3,3-dimethylbutanoyl)-4-hydroxyN-(4-(4-methylthiazol-5-yl)benzyl)pyrrolidine-2-carboxamide (VH298). J. Med. Chem. 2018, 61, 599-618. 